DEMOCRACIA, DESENVOLVIMENTO HUMANO E DIREITOS HUMANOS

DEMOCRACY, HUMAN DEVELOPMENT AND

HUMAN RIGHTS

Reprodução e autorização: revistadebates@ufrgs.br

Guilhermo O’Donnell

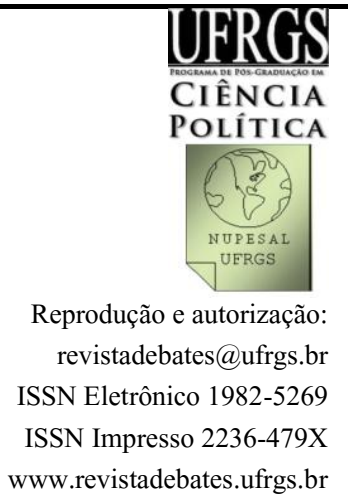

\title{
I. Introdução
}

O presente texto parte de uma premissa fundamental: um regime democrático (que defino abaixo) é um componente fundamental da democracia, porém não esgota seu significado. Espero mostrar que isto é verdade em todos os casos, mas se fez particularmente evidente nos estudos das novas (e algumas não tão novas) democracias no Sul e no Leste. Geralmente, a Ciência Política contemporânea se limita ao estudo do regime político. Esta limitação oferece a segurança de um campo de indagação obviamente importante e aparentemente bem delimitado. Aventurar-se além do regime é perigoso: facilmente pode-se cair em um terreno escorregadio, no final do qual cada termina identificando a democracia com o que lhe agrada. Uma forma de evitar este risco é atar uma corda a um fundamento relativamente firme - o regime - e com sua ajuda descer cautelosamente pelo abismo, tentando ver como uma dimensão - a democracia - co-constitui alguns dos fenômenos, que durante a descida observamos. É claro, não é qualquer corda que serve. A que escolhi provém de uma dimensão importante, ainda que frequentemente ignorada que, com o devido cuidado, pode descobrir-se inclusive no nível de regime democrático: uma concepção particular do ser humano cum cidadão como um agente. Esta é a linha fundamental, o fio que vou seguir na esperança de que nos ajude a forjar uma melhor compreensão da democracia, especialmente tal como ela existe na realidade contemporânea da América Latina.

O que segue é, então, teoria democrática com intenção comparativa. Como tal, inclui uma discussão teórica de alguns aspectos da democracia e suas conexões com o desenvolvimento humano e os direitos humanos. Desta forma, este texto inclui uma dimensão empírica, concretizada na proposição de diversos critérios que creio úteis para avaliar a 
qualidade das democracias políticas existentes e suas mudanças ao longo do tempo. O que segue é uma primeira exploração desses temas. É claro, alimenta-se de contribuições de diversas disciplinas, porém observa vários temas de ângulos pouco explorados. Por estas razões o presente texto é um fragmento de teoria democrática. Aqui argumento basicamente sobre seus fundamentos e algumas de suas consequências. Pouco falo sobre outros tópicos extremamente importantes, tais como quem são os atores políticos reais - individuais e coletivos - em uma determinada circunstância, ou como exercem seu poder os governos e os estados em cada caso, ou quais são as conseqüências domésticas das diversas dimensões da globalização. Além do mais, embora o estado ocupe um lugar central em minha análise, devido a limitações de espaço e de tempo, minha discussão sobre o mesmo, sobretudo como um conjunto de burocracias e como foco de identidade, é sumária ${ }^{1}$. De qualquer modo, espero que a presente incursão, para além do regime, mostre que a corda que utilizo pode suportar explorações adicionais. Estou persuadido de que, inclusive ao custo da perda de parcimônia que resulta de concentrar-se exclusivamente no regime, este tipo de incursão pode abrir temas e ângulos de interrogação não só intelectualmente estimulantes, mas também úteis para melhorar o funcionamento e os impactos da democracia.

Refletindo sobre o fator fundador da democracia - a concepção do ser humano como um agente - cheguei à conclusão que existem estreitas conexões entre a democracia, o desenvolvimento humano e os direitos humanos. Além de destacar estas conexões, no presente texto afirmo que elas nos conduzem a avaliar a qualidade das democracias existentes, e proponho alguns critérios para lidar com esta questão. Meu argumento é que a democracia, o desenvolvimento humano e os direitos humanos estão baseados em uma concepção similar de ser humano como um agente ${ }^{2}$. Observo também que esta perspectiva foi adotada, implícita, porém claramente, em várias convenções e tratados internacionais e regionais ${ }^{3}$, assim como nos Informes sobre Desenvolvimento Humano do PNUD. Adiciono que esta concepção

\footnotetext{
${ }^{1}$ Esta á uma importante ressalva. Embora avance mais sobre este tema em um texto que escrevi após este (O’DONNELL, 2002a), as complexas - e muito pouco estudadas - relações entre a democracia e diversas dimensões do estado as analiso em um livro em preparação e no qual retomo, embora nem sempre desde o mesmo ângulo, um velho texto meu (O’DONNELL, 1978). Até então, não posso deixar de incorrer em várias simplificações e omissões.

${ }^{2}$ Outra ressalva importante. Em várias conversas, José Nun me alertou sobre o perigo que esta concepção seja vista como individualista. Na verdade, o fato de que um dos níveis relevantes de uma teoria seja o individual, não a faz necessariamente individualista. Neste caso específico, como espero ficará claro ao longo do texto, na minha teorização o individuo não entra nas relações sociais já pré-constituído como tal, conforme postulam as teorias individualistas; ao contrário, se constitui propriamente em agente em e por um tecido complexo de relações sociais, não poucas das quais, nas sociedades contemporâneas, estão legalmente estipuladas.

${ }^{3}$ Para una valiosa apresentação e discussão destes documentos internacionais e suas principais interpretações, feitas a partir de uma perspectiva convergente com a minha, ver Held (2002).
} 
estabelece um horizonte em perpétuo movimento que impede considerar o desenvolvimento humano, os direitos humanos e a democracia como sendo fenômenos estáticos ou unidimensionais, como faríamos se pensássemos o desenvolvimento só como um aumento na disponibilidade de recursos materiais, ou se reduzíssemos os direitos humanos à proteção contra a violência física e ao temor a ela ou, da mesma forma, se restringíssemos a democracia ao regime.

Até onde sei, estas conexões e a exploração de suas conseqüências são em boa medida terra incógnita. Um perigo de ingressar nela sem um bom mapa é perder-se nas muitas ramificações que aparecem. Embora não tenha eliminado inteiramente este perigo, guiei minha pesquisa pelas seguintes perguntas: Qual é o terreno que estas correntes têm em comum? Porque deveríamos nos preocupar, para além das razões instrumentais (tal como, digamos, sua presumível contribuição ao crescimento econômico) pela democracia e sua qualidade? Quais são os parâmetros conceituais sob os quais a questão da qualidade da democracia pode ser levantada frutiferamente? Como poderíamos estabelecer uma conversação entre estas três correntes que lhes permita alimentar-se mutuamente e fomentar na teoria e na pratica a perspectiva dos seres humanos como agentes, que as três, como espero mostrar, compartilham?

Admito que partes do texto que seguem não são fáceis. Para ajudar a segui-lo ao longo do mesmo incluo proposições que vão destilando as principais conclusões alcançadas ${ }^{4}$. Também incluo sugestões sobre como avaliar (ou auditar) a qualidade da democracia.

\section{Um primeiro olhar sobre o desenvolvimento humano e sobre os direitos humanos}

O conceito de desenvolvimento humano que foi proposto e amplamente difundido pelo PNUD implica, junto com as contribuições de Amartya Sen - per se e por sua influência nos "Informes" do PNUD - uma mudança das visões dominantes sobre o desenvolvimento. Ao invés de concentrar-se em medidas agregadas do desempenho econômico, a perspectiva centralizada no desenvolvimento humano começa e termina pelos seres humanos. O conceito implica perguntar-se pelas possibilidades de cada individuo de alcançar "las más elementales capacidades, tales como la de vivir una vida larga y saludable, ser socialmente reconocido y disfrutar de un estándar de vida decente". Estas são consideradas condições básicas "para que cada persona pueda llevar una vida de respetable y valorable". "el desarrollo humano [...] es un proceso de enriquecimiento de las posibilidades humanas",

\footnotetext{
${ }^{4}$ Com o mesmo propósito incluo uma lista destas proposições como Anexo 3.

${ }^{5}$ PNUD (2000, p. 20).

${ }^{6}$ Ibid. p. 2.
} 
mas também se converte no padrão de medida com o qual avaliar outros aspectos do desenvolvimento.

Ao longo de seus Informes sobre o Desenvolvimento Humano, tanto mundiais como regionais, o PNUD vem extraindo destas considerações, cada vez mais explicitamente, um importante corolário: a conquista e a expansão de um conjunto de capacidades básicas não é considerada só algo ao que os seres humanos têm um direito moral, nem só una meta que as pessoas de boa vontade podem propor, mas um direito de todos os que sofrem privação dessas capacidades. Este é um autêntico interesse humano, cuja satisfação pode ser legitimamente exigida dos demais, especialmente do estado.

A afirmação desses direitos me parece um passo bastante radical e, inclusive, institucionalmente corajoso por parte do PNUD. Para começar, a existência desse tipo de direitos é discutida - seja porque simplesmente são negados, seja porque se pretende que sejam impraticáveis - por influentes correntes na filosofia, teoria ética e jurisprudência atuais, e é simplesmente ignorada pela maior parte da Ciência Política. Por outro lado, em recentes Informes sobre Desenvolvimento Humano esta afirmação se associa a uma discussão sobre os direitos humanos e sobre os campos de sobreposição e diferença entre estes dois conceitos. Esta convergência não é acidental: uma vez que a conquista de certas capacidades básicas (por exemplo, certos níveis mínimos de alimentação e de saúde) é definida como um direito, alguns dos interesses humanos obviamente vinculados a elas (por exemplo, a integridade física) logicamente tendem a ser definidos como direitos não menos fundamentais e exigíveis.

Estas duas perspectivas têm alguns elementos cruciais em comum: ambas começam e terminam pelos seres humanos e ambas se perguntam qual pode ser, ao menos, um conjunto mínimo de condições, direitos e/ou capacidades que os permitam viver de forma apropriada a sua condição de tais. Na verdade, em suas origens, o conceito de desenvolvimento humano se concentrava no contexto social, enquanto que o de direitos humanos o fazia no sistema legal e na prevenção e reparação da violência estatal. Entretanto, o Informe sobre Desenvolvimento Humano do ano 2000 e sua discussão sobre diretos humanos, por um lado, e a crescente atenção dos estudiosos e militantes dos direitos humanos aos fatores sociais, por outro ${ }^{7}$, revelam uma importante convergência: ambas correntes se ocupam de conjuntos de condições e capacidades que, nos termos de Sen, são valiosos na medida em que permitem aos indivíduos eleger livremente os funcionamentos (isto quer dizer, os cursos de ação que determinam o que eles realmente fazem e são) apropriados a sua condição de seres humanos que, como argumento abaixo, partilham a condição - e a conseguinte dignidade - de ser agentes.

\footnotetext{
${ }^{7}$ É interessante observar que Anistia Internacional esta discutindo incluir em seu mandato a promoção de direitos sociais, econômicos e culturais (ver The Economist, 2001).
} 
Se notará que acima utilizei o vago termo "apropriado". A forma de especificar este termo é aprimorar uma concepção do ser humano com referência a qual agente possa predicar esse atributo de "apropriado". Nos submergimos aqui em águas profundas. Em primeiro lugar, em termos da lógica de seus argumentos, tanto os patrocinadores do desenvolvimento humano como dos direitos humanos devem ser rigorosos universalistas, ao menos no que se refere à realização e defesa dos direitos, condições sociais e capacidades "básicas" que propiciam. Os proponentes da escravidão, da existência de raças inferiores, da inferioridade inata da mulher, da irredutível singularidade das culturas, os cínicos de todo tipo, os céticos consistentes, e os governos que não querem ser avaliados por seu desempenho nestas matérias, rejeitam este universalismo. Em contraste, os estudiosos e praticantes do desenvolvimento humano e dos direitos humanos se perguntam sobre pelo menos algumas condições e direitos básicos que seriam aplicáveis a todos os seres humanos, independentemente das condições sociais, culturais e biológicas de cada um $^{8}$.

Em segundo lugar, cabe aos universalistas explicitar a concepção subjacente à reivindicação de que todos podem alcançar ao menos um conjunto básico de capacidades e direitos. Estou persuadido que este elemento subjacente - e fundador - é uma concepção moral do ser humano como um agente, quer dizer, alguém que está normalmente dotado de razão prática e de autonomia suficiente para decidir que tipo de vida quer viver, que tem capacidade cognitiva para detectar razoavelmente as opções que se encontrão a sua disposição e que se sente - e é interpretado/a pelos demais como - responsável pelos cursos de ação que elege. É claro, posso abdicar destes atributos, ou eleger cursos de ação que sejam inúteis ou inclusive auto-destrutivos, ou posso ter a desgraça de haver nascido, digamos, com um forte prejuízo de minhas capacidades cognitivas. Estas são questões importantes sobre as quais voltarei, dado que a questão central, porque afeta a milhões de pessoas, se refere a situações nas quais de maneira objetiva (quer dizer, muito além das preferências dos que estão envolvidos) vêem objetivamente obstaculizada a probabilidade de converter-se plenamente em agentes, depois da heteronomia - biologicamente determinada - da infância. Recapitulo agora com algumas proposições.

\footnotetext{
${ }^{8}$ Em termos de desenvolvimento humano, talvez não haja afirmação deste universalismo mais eloquente (embora implícita) que a recente incorporação aos Informes sobre Desenvolvimento Humano de dados sobre questões de gênero e, em geral, sobre a situação das mulheres. O óbvio fundamento desta incorporação é a crença universalista que as mulheres não têm menos direitos que os homens, e que as privações a que elas se encontram, frequentemente, submetidas merecem considerações especiais e obrigações do estado e de outros atores sociais. É claro, esta crença concorre com perspectivas que estão ainda profundamente arraigadas em muitas partes do mundo.
} 
1. Os conceitos de desenvolvimento humano e de direitos humanos compartilham uma subjacente perspectiva universalista do ser humano como um agente.

2. Esta perspectiva conduz à pergunta de quais seriam as condições, capacidades e/ou direitos básicos que normalmente permitem a um individuo funcionar como um agente.

Mencionei já quão difícil - e, inclusive, controverso - é o primeiro ponto; o segundo, embora mais prático e empírico, não é menos complexo. Antes de abordar estas questões, convêm que na seção que segue, proponha minhas definições de alguns conceitos que usarei extensamente ao longo deste texto. Na seção subsequente incorporarei outra dimensão, também fundamentada na agência: a democracia política.

\section{Definições}

Começo pela definição de estado. Pelo mesmo, entendo:

Um conjunto de instituições e de relações sociais (boa parte delas sancionadas pelo sistema legal desse estado) que normalmente penetra e controla o território e os habitantes que esse conjunto pretende delimitar geograficamente. Essas instituições têm como último recurso, para efetivar as decisões que tomam, à supremacia no controle dos meios de coerção física que algumas agências especializadas do mesmo estado normalmente exercem sobre esse território. Essa supremacia geralmente respalda a pretensão que as decisões estatais sejam vinculantes para todos os habitantes de seu território.

Esta é uma definição que se pode reconhecer como de cunho weberiano. Particularmente, ela esta focada no que o estado é, não na enorme variedade de coisas que o estado faz ou pode fazer. Porém, por razões que veremos abaixo, minha definição se separa da weberiana ao não postular como atributo componente do estado que sua coerção, ou violência, deva ser legítima; esta característica convém considerá-la uma variável histórica, tanto de países como de diferentes períodos em cada país (veremos que o mesmo vale para as outras dimensões do estado incluídas na definição que propus). Outra característica desta definição, compartilhada com Weber e outros autores clássicos, é que ela aponta diretamente ao tema do poder, em termos da grande concentração de poder (mais precisamente, poderes) implicada pelo surgimento e funcionamento do estado.

Vemos que, de acordo com esta definição, o estado inclui ao menos três dimensões. Uma, a mais óbvia e reconhecida quase exclusivamente pela literatura contemporânea, é o 
estado como um conjunto de burocracias ${ }^{9}$. Estas burocracias, geralmente organizações complexas, têm legalmente designadas responsabilidades destinadas a alcançar ou proteger algum aspecto do bem, ou interesse público, geral.

O estado é também um sistema legal, uma trama de regras legalmente sancionadas que penetram e co-determinam numerosas relações sociais. Contemporaneamente, especialmente em democracias, a conexão entre as burocracias do estado e o sistema legal é íntima: as primeiras se supõem que atuam em termos de faculdades e responsabilidades que lhes são legalmente designadas por autoridades pertinentes, pois o estado se expressa na gramática do direito. Juntos, as burocracias do estado e o Direito presumem gerar, para os habitantes de seu território, o grande bem público da ordem geral e a previsibilidade de uma ampla gama de relações sociais. Ao fazer isto, o estado (mais precisamente, os funcionários que falam em seu nome) presume garantir a continuidade histórica da unidade territorial respectiva, usualmente concebida como uma nação.

Estas pretensões levam à terceira dimensão do estado: intenta ser um foco de identidade coletiva para os habitantes de seu território. Tipicamente os funcionários do estado, especialmente os que ocupam posições em sua cúpula institucional, afirmam que o seu é um estado-para-a-nação ou (sem entrar em detalhes desnecessários neste momento) um estadopara-o-povo. Com estas afirmações eles convidam ao reconhecimento generalizado de um "nós" que aponta para criar uma identidade coletiva ("somos todos argentinos-brasileirosperuanos", etc) que, segundo se postula, estaria acima de, ou deveria prevalecer sobre, os conflitos e clivagens sociais. Temos então três dimensões do estado, que poderiam resumir-se na relativa eficácia de suas burocracias, efetividade de seu sistema legal e credibilidade de seu conjunto.

Aponto que, seguindo o cunho weberiano da definição que propus estas três dimensões não devem ser atribuídas a priori a qualquer estado. Elas são tendências que talvez felizmente - nenhum estado materializou completamente, e que alguns estados distam de haver alcançado medianamente. No que diz respeito ao estado como um conjunto de burocracias, seu desempenho pode se desviar seriamente de cumprir as responsabilidades que lhe foram designadas; por sua parte, o sistema legal pode per se ter sérias falências e/ou não se estender efetivamente a diversas relações sociais, ou ainda a vastas regiões; e no que diz respeito ao estado como foco de identidade coletiva, sua pretensão de ser verdadeiramente um

\footnotetext{
${ }^{9}$ Ultimamente as ciências sociais contemporâneas, principalmente as anglo-saxãs e sua forte influência no resto, têm prestado escassa atenção ao tema do estado, e quando o fizeram o reduziram a uma só dimensão, isto é, a um conjunto de burocracias (este é o caso, por exemplo, da influente coleção de Evans et. al., 1985). Embora obviamente esta não tenha sido a intenção de alguns destes autores, essa redução tem ajudado as assim chamadas correntes "neoliberais" a demonizar o estado como o culpado de todo tipo de patologias que se encontram em uma relação de soma zero com a sociedade.
} 
estado-para-a-nação pode não ser verossímil para boa parte da população ${ }^{10}$. Vemos então que as três dimensões do estado - e, em conseqüência, também seu caráter efetivamente legítimo e vinculante para todos seus habitantes - são historicamente contingentes; portanto, a medida de sua realização deve ser estabelecida empiricamente.

A seguir defino os conceitos de regime, regime democrático e governo.

Por regime entendo os padrões, formais e informais, e explícitos e implícitos, que determinam os canais de acesso às principais posições de governo, as características dos atores que são admitidos e excluídos de tal acesso, os recursos e as estratégias permitidas para realizá-lo, e as instituições através das quais esse acesso ocorre e pelas quais, uma vez realizado, são tomadas as decisões governamentais $^{11}$.

Por regime democrático entendo um no qual o acesso às principais posições de governo se alcança mediante eleições que são por sua vez limpas $e$ institucionalizadas e no qual existem, durante e entre essas eleições, diversas liberdades - habitualmente chamadas "politicas" - tais como as de associação, expressão, movimento e de disponibilidade de informação não monopolizada pelo estado ou por agentes privados ${ }^{12}$.

Por governo entendo as posições na cúpula das instituições do estado: o acesso às ditas posições se realiza através do regime, o qual permite aos funcionários respectivos tomar, ou autorizar a outros funcionários a tomar, decisões que são normalmente emitidas como regras legais obrigatórias sobre o território delimitado pelo estado ${ }^{13}$.

\footnotetext{
${ }^{10}$ Repito a ressalva expressa na nota de rodapé 1 . Nas declarações do texto principal passo por alto diversos aspectos do estado que são intrinsecamente contraditórios, sobretudo a partir das tendências inerentemente autoritárias de sua dimensão burocrática e de sua condição de estado de e em uma sociedade capitalista, especialmente de capitalismos como o capitalismo latinoamericano. Estas características por sua vez têm complexas consequências para a relação entre o estado e a democracia. Porém como já anticipei, devo adiar estas discussões para um livro próximo; até então apelo à benevolencia dos leitores/as pelas simplificações e omissões que deixo aqui sugeridas.

${ }^{11}$ Esta é, com algumas adaptações, a definição apresentada em O’Donnel e Schmitter (1994, p. 118, nota de rodapé 1).

${ }^{12}$ Retomo este tema na seção seguinte.

${ }^{13}$ Estas decisões não são necessariamente universais. O crescente uso por parte dos estados modernos de legine, quer dizer, regras dirigidas a problemas, regionais ou grupos específicos, requerem este esclarecimento. No entanto, se supõe que toda regra legal tem validade sobre a totalidade do território delimitado pelo estado.
} 
De acordo com estas definições, o governo é una parte fundamental de estado, sua cúpula institucional. Por sua vez, o regime é uma mediação entre o estado e a sociedade: consiste de um conjunto de instituições, regras e práticas que regula o acesso desde a sociedade às mais altas posições no estado. Em um regime democrático o principal canal institucional esta integrado por partidos políticos que competem livremente para ganhar esse acesso $^{14}$. Sob este regime o resultado desta competição determina quem ocupa por um tempo determinado (em regimes presidencialistas) ou de acordo com condições pré-estabelecidas (em regimes parlamentares) as posições governamentais ${ }^{15}$.

Porém, está claro, o sistema de representação democrática que implica este regime esta longe de esgotar os meios de representação de interesses e identidades que influenciam sobre as decisões (e omissões) do governo e das burocracias estatais. Diversos interesses econômicos e coorporativos nacionais e (crescentemente) transnacionais, interesses e visões das próprias burocracias estatais, demandas populares, pressões pontuais e às vezes invisíveis de diversos poderes, interesses privados dos governantes e funcionários estatais, as próprias ideologias e visões desses, e outros "insumos" geralmente determinam complexamente as mencionadas ações e omissões. Isto leva a perguntar-se sobre o grau em que pesam efetivamente, nessas decisões e omissões, os insumos provenientes do regime e suas instituições representativas em relação a outros insumos. Tenhamos em conta que pelo lado do regime democrático provém a principal fonte de legitimação das políticas públicas (e, conseqüentemente, no agregado, da credibilidade do estado e do governo), a pretensão de representar o conjunto da cidadania e as preferências e aspirações que se supõe expressos em eleições limpas e institucionalizadas. Os outros insumos, públicos ou ocultos, legais ou ilegais, embora resultem em decisões que se pode aceitar que beneficiaram algum aspecto do bem público, carecem dessa capacidade de legitimação propriamente democrática das políticas públicas. $\mathrm{O}$ resultado, em todas as democracias realmente existentes, é que o regime

\footnotetext{
${ }^{14}$ Nota-se que, portanto e contrariamente ao uso corrente, esta mediação que é o regime "não faz" nada. Os que fazem - quer dizer atuam, tomam decisões, etc - são, na "ponta social" do regime, os eleitores, militantes de partidos e outros; e em sua "ponta estatal" os governantes e funcionários estatais. Algumas conversas com Carlos Strasser me permitiram esclarecer este ponto, embora eu duvide que Strasser compartilhe tal como o formulo.

${ }^{15}$ Com exceção dos tribunais superiores e da cúpula das forças armadas, embora nos casos de regimes democráticos solidamente institucionalizados estas dependem de um ministro de defesa (ou designação equivalente) designado pela autoridade eleita. Da mesma forma, em tempos recentes se difundiu a pratica de eximir deste requisito os diretores de bancos centrais.
} 
é só uma parte do funcionamento e dos insumos de influência a que estão sujeitos os governos e as burocracias estatais ${ }^{16}$.

Isto levanta importantes problemas práticos: em que grau (e em cada caso, período e tipo de política pública) os insumos provenientes do regime pesam sobre os restantes? Em que medida a autoridade que invoca-se no sentido de representar ou realizar aspirações expressas do regime democrático corresponde à realidade? Em que circunstâncias seriam admissíveis desvios dessas aspirações e/ou de promessas feitas durante o processo eleitoral? Em que medida os insumos extra-regime são ocultos, ilegais e/ou corruptos? Estas questões levantam também problemas empíricos complicados, que entre outras coisas devem ter conseqüências no que diz respeito à avaliação da qualidade das respectivas democracias. Só em casos negativos bastante extremos se pode responder estas perguntas com aproximação suficiente. Esses casos, infelizmente, não faltaram na experiência recente da América Latina. Neles os insumos do regime foram frágeis e/ou foram capturados por outros interesses, e às vezes esses governos mostraram cumplicidade com interesses que dificilmente poderia argumentar-se levam ao obtenção de algum bem propriamente público ou geral. Estas circunstâncias não ajudaram à eficácia, à efetividade nem à credibilidade desses estados e governos, nem por certo à qualidade destas democracias.

As reflexões precedentes servem como indicação de uma importante preocupação deste texto: o escasso poder que na América Latina tem os governos democraticamente eleitos e, em geral, os estados, para avançar na democratização de seus respectivos países ${ }^{17}$. Isto leva a outras perguntas, que devem ser confrontadas por mais difíceis que sejam. Não se trata só de saber o que é o que o estado é, mas também para que e para quem - ou, dito de maneira equivalente, para que nação (ou povo) - é e deveria ser esse estado nas presentes circunstancias da América Latina; isto é, quando fizemos a realização importantíssima de conquistar um regime democrático, mas quando na maioria de nossos países este regime pouco ou nada consegue expandir-se na direção da democratização da sociedade e do próprio estado. Isto é grave por si mesmo e porque, a médio e longo prazo, afeta à qualidade de uma democracia e à sobrevivência do próprio regime.

\footnotetext{
${ }^{16}$ Esta complexidade (que Bobbio, 1986, inclui entre "as promessas não realizadas da democracia") costuma ser ignorada pelas teorias da democracia que se centralizam exclusivamente no regime; comento e critico estas teorias em O’Donnell (2000). Ela em troca é reconhecida no conceito de "regimes parciais" proposto por Schimitter (1992) e, sobretudo, nas interessantes e detalhadas reflexões que sobre o tema oferece Strasser (entre outros, 1996, 1999).

${ }^{17}$ Parafraseio aqui una observação de Malloy (1989). É claro, este problema não deriva exclusivamente da fragilidade do governo e do estado; no entanto, exceto para crentes fervorosos nos mercados míticos ou maravilhosas sociedades civis, essas fragilidades tem consequências importante.
} 
Neste ponto quero reforçar novamente que na presente seção me limitei a oferecer definições de alguns conceitos que necessitarei no resto do presente texto. Porém, embora seja claro que a estas definições subjaz uma concepção teórica, por razões de espaço e para poder concentrar-me no tema, já suficientemente complexo, do presente texto, não apresento aqui essa teorização.

\section{Um Regime Democrático, Democracia ou Poliarquia}

Após os prolegómenos precedentes, devemos nos concentrar na rocha na qual, mais tarde, amarraremos nossa corda. Em um regime democrático as eleições são competitivas, livres, igualitárias, decisivas e inclusivas, e aqueles que votam são os mesmos que têm direito a ser eleitos: são cidadãos(ãs) políticos(as). Se as eleições são competitivas, os indivíduos enfrentam ao menos seis opções: votar no partido A, votar no partido B, não votar, votar em branco, anular o voto ou adotar algum procedimento que determine ao acaso qual das opções anteriores colocar em prática. Além disso, os (ao menos dois) partidos que competem devem ter possibilidades razoáveis de fazer conhecer suas opiniões a todos seus (reais e potenciais) eleitores. Para ser uma eleição democrática ela deve também ser livre, no sentido de que os cidadãos não devem sofrer coerção, ao menos ao tomar sua decisão de voto e ao votar. Para que a eleição seja igualitária, todos os votos devem ter o mesmo peso, e devem ser contados desse modo sem fraude, independentemente da posição social, da filiação política ou de qualquer outra característica de cada um ${ }^{18}$. Por último, as eleições devem ser decisivas, em vários sentidos. Primeiro, os vencedores passam a ocupar os postos governamentais que disputaram. Segundo, esses governantes, baseados na autoridade atribuída a esses postos, podem de fato tomar as decisões que um sistema democrático legal/constitucional normalmente autoriza. Terceiro, esses governantes terminam seus mandatos nos termos e/ou sob as condições estipuladas por esse mesmo sistema ${ }^{19}$.

\footnotetext{
${ }^{18}$ Digo aqui que, no momento de contar os votos, cada voto deve ser computado como um (ou, no caso de votos plurais, na mesma quantidade que qualquer outro voto). Com isso, aludo ao problema que resulta de regras de agregação de votos que provocam que em certos distritos eles pesem mais - e em alguns casos, significativamente mais - que em outros distritos (em relação com a América Latina e a severa sobrerrepresentação de alguns distritos em alguns países, ver Samuels e Snyder, 2001, e Calvo e Abal Medina, 2001). Em certo ponto, a sobrerrepresentação aparece tão destacada que qualquer aparência de voto igualitário desaparece. Antes de chegar a esse ponto, creio que é possível sustentar que a qualidade de uma determinada democracia é maior quanto menos sobrerrepresentação exista, ou seja, quanto mais conte cada voto verdadeiramente igual aos demais.

${ }^{19}$ Em O'Donnell (2000) propus agregar esta característica de "decisividade" à lista habitual de atributos das eleições em um regime democrático. A omissão daquela característica pode justificar-se em países nos quais é quase impensável que os ganhadores de uma eleição não sejam admitidos aos respectivos postos, ou que eles
} 
Observe-se que os atributos que acabo de especificar não dizem nada a respeito da composição do eleitorado. Existiram democracias oligárquicas - aquelas que restringiam o sufrágio - que satisfizeram os atributos indicados. Mas, como consequência dos processos históricos de democratização nos países pioneiros ${ }^{20}$ e de sua difusão em outros países, a democracia adquiriu outra característica, a inclusividade: o direito de votar e de ser votado se aplica, com poucas exceções, a todos os membros adultos de um país.

Para resumir, em adiante chamo de eleições limpas as que reúnem a condição conjunta de serem livres, competitivas, igualitárias, decisivas e inclusivas ${ }^{21}$. Este tipo de eleição implica que os governos possam perder eleições e acate os resultados ${ }^{22}$. Esta é uma característica específica de um regime democrático, ou democracia política, ou poliarquia, três expressões que uso como equivalentes. Em outros casos pode haver eleições (como ocorria nos países comunistas ou com outros países autoritários, ou na república Veneziana, ou para a eleição do Papa, ou inclusive em certas juntas militares), mas só a democracia política tem este tipo de eleição que reúne todos os critérios acima especificados.

Contudo, contra o que afirmam influentes correntes "minimalistas" da Ciência Política contemporânea ${ }^{23}$, as eleições limpas não são suficientes para caracterizar um regime democrático. Neste tipo de regime, as eleições não se referem a um único evento, mas a uma série de eleições que continuam - e das quais se espera que continuem - em um futuro indefinido. Ao dizer isso, definimos uma instituição.

Sob um regime democrático, as eleições estão institucionalizadas: praticamente todos os atores, políticos e não políticos, deduzem que seguirá havendo indefinidamente eleições limpas. Isto implica que esses atores também dão por certo que alguns direitos "políticos" (aos quais me referirei mais adiante) continuarão sendo efetivos. Onde essas expectativas são

acabem em suas funções por meios inconstitucionais. Contudo, a experiência da América Latina mostra abundantemente que estas circunstâncias não podem ser tidas como certas, seja porque acontece algum tipo de golpe militar ou porque, como o caso de Fujimori no Peru (ou, para o caso Yeltsin, na Rússia), um presidente democraticamente eleito cancela a democracia ao despedir ilegalmente altos funcionários judiciais e/ou fechar o congresso. No meu op. cit. argumento que esta e outras pressuposições silenciadas da Ciência Política contemporânea devem ser criticamente revisadas se a teoria democrática quer chegar a alcançar uma amplitude comparativa adequada.

${ }^{20} \mathrm{O}$ uso as expressões "países iniciadores" e "Noroeste" para aludir sucintamente aos países localizados no quadrante Noroeste do mundo e, com não pouca licença geográfica, à Austrália e à Nova Zelândia.

${ }^{21}$ Tal como acontece com os mercados, poucas eleições, se é que existe alguma, são "perfeitas" (como a eleição presidencial de 2000, nos Estados Unidos mostrou patentemente); ver sobre o tema Elklit e Svensson (1997). Esta condição aponta a questão da diferente qualidade ou graus de democratização do regime, à qual me ocupo mais adiante.

${ }^{22}$ Przeworski (1991, p. 10).

${ }^{23}$ Para uma discussão desta e de outras correntes, ver O’Donnell (2000). 
generalizadamente compartilhadas, as eleições limpas estão institucionalizadas. Esses casos são diferentes, não somente aos de eleições autoritárias, mas também àqueles nos quais, inclusive se uma determinada eleição foi limpa, não existe uma presunção generalizada de que eleições semelhantes vão seguir tendo lugar. Apenas no primeiro tipo de situação os agentes importantes ajustam racionalmente suas estratégias à expectativa de que as eleições limpas vão seguir existindo no futuro. Normalmente a convergência destas expectativas aumenta a probabilidade de que este tipo de eleição seguirá, em efeito, ocorrendo ${ }^{24}$. Do contrário, os agentes relevantes investirão em recursos diferentes das eleições como meio para ascender às mais altas posições do regime ${ }^{25}$.

Vemos que as eleições limpas e institucionalizadas são um componente central do regime democrático já que são, com as exceções já mencionadas, o único meio de acesso para as principais posições de governo. Mas isto, todavia, não é suficiente para caracterizar um regime democrático. Vimos que, nesse regime, cada eleitor tem ao menos seis opções. Devemos agora recordar algo que frequentemente é esquecido: todos os(as) cidadãos(ãs) têm direito não só a votar mas também de tentar serem eleitos(as). Que cada um queira ou não exercer esse direito é irrelevante em relação ao fato de que cada cidadão(ã) é portador da autoridade potencial de participar nas decisões governamentais; ou seja, de compartilhar a grande responsabilidade de participar na tomada de decisões vinculativas que, em última instância, podem ser respaldadas pela supremacia estatal no controle dos meios de coerção sobre seu território.

O ponto importante sobre os direitos políticos de participação - a votar e a ser eleito(a) - é que eles definem um agente. Esta definição é uma definição legal; esses direitos são atribuídos pelo sistema legal a quase todos os adultos no território de um estado, com algumas exceções que estão, elas mesmas, legalmente definidas. Esta atribuição é universalista: corresponde a quase todos os adultos em um território, independentemente de sua condição social e de qualquer característica adscritiva distintas da idade e da nacionalidade. No nível em que estamos discutindo - um regime democrático - o reconhecimento das pessoas como agentes implica a atribuição legal da capacidade de cada cidadão(ã) de fazer opções que são consideradas suficientemente razoáveis como para ter consequências significativas em termos da agregação de votos e do desempenho de funções no estado e no governo. Os indivíduos podem não exercer esses direitos; contudo, o sistema

\footnotetext{
${ }^{24}$ Esta probabilidade de duração não quer dizer que depois de $\mathrm{N}$ rodadas de eleições uma democracia tenha se "consolidado" (como argumenta, por exemplo, Huntington, 1991), ou que outros aspectos do regime estejam institucionalizados ou em vias de ser. Para uma discussão destas questões, ver O’Donnell (1996).

${ }^{25}$ Inclusive supondo que os agentes prevejam que as eleições em T1 serão limpas, se eles acreditam que existe uma probabilidade significativa de que as eleições em T2 não vão ser, por uma regressão explorada nos dilemas do prisioneiro com números fixos de repetição, os agentes farão este tipo de inversões extra-eleitorais já em T1.
} 
legal constrói a todos como igualmente capazes de exercer esses direitos e suas correspondentes obrigações (tais como, digamos, se abster de fraude ou violência durante as eleições, ou atuar dentro dos limites legalmente estabelecidos nas funções de governo). Esta atribuição cria um espaço de igualdade universal, legalmente dotada para todos os que satisfazem os requisitos da cidadania.

Note-se que esta atribuição implica designar a condição de agentes a todos os que se aplica - os(as) cidadãos(ãs). Esta condição diz respeito às relações diretamente referidas a um regime - democrático - baseado em eleições limpas e institucionalizadas. Observe-se, no entanto, que esta é uma atribuição de agência feita mediante um universalismo limitado: se aplica a quase todos os adultos no território de um estado organizado segundo um regime democrático, não, por exemplo, aos estrangeiros nesse território. Este universalismo limitado se distingue do universalismo ilimitado, pois este último se predica para a garantia e expansão do desenvolvimento humano e os direitos humanos através de todo tipo de países, estados e regimes. Entretanto, o universalismo limitado dos direitos políticos tem uma vantagem distintiva sobre o segundo, a de identificar claramente aos destinatários desses direitos: esses podem ser reclamados, por meio do sistema legal, ao estado e a qualquer indivíduo que possa tê-los infringido. Trata-se, então, de direitos subjetivos (legalmente acionados) que existem pelo simples, mas fundamental, fato de que estes indivíduos vivem em um estado territorialmente delimitado que contém um regime democrático.

Vista desta perspectiva, a democracia política não é o resultado de algum tipo de consenso, ou eleição individual, ou contrato social, ou processo deliberativo. É o resultado de uma aposta institucionalizada. O sistema legal atribui a cada indivíduo múltiplos direitos e obrigações. Os indivíduos não os escolhem; desde seu nascimento se encontram imersos em uma complexa rede social; esta rede social inclui direitos e deveres estabelecidos e respaldados pelo sistema legal do estado em que vivem. Somos seres sociais muito antes de tomar qualquer decisão voluntária e nas sociedades contemporâneas uma parte importante deste ser está legalmente definido e regulado ${ }^{26}$. Qual é a aposta? É que, em uma democracia política, cada ego deve aceitar que todo alter (ou seja, todos os que habitam um território de um estado que contém um regime democrático) participa, votando e eventualmente sendo eleito, no ato - eleições limpas e institucionalizadas - que determina quem os vai governar por

\footnotetext{
${ }^{26}$ Volto aqui ao comentário da nota de rodapé número 2. Espero que esta formulação e várias que seguem, embora sucintas, sirvam para dissipar confusões de que a posição teórica que sustento é individualista. Para uma discussão pertinente sobre este tema - e convergente com a minha posição sobre este tema - ver Lechner (2000) e seus comentários ao presente texto; ver também Berger e Luckman (1966). Ademais, apesar de suas importantes diferenças, se existe algo que os grandes clássicos da sociologia e da economia política têm em comum (basta mencionar Marx, Weber, Durkheim e Simmel) é esta visão "socializada", não individualista, da agência humana.
} 
um tempo. Esta é uma aposta institucionalizada, porque se impõe a cada um independentemente de suas preferências subjetivas: cada ego deve aceitá-la inclusive se crê que permitir a certos indivíduos votar ou ser eleito é inadequado. Ego não tem outra opção senão correr o risco de que partidos e políticas "equivocadas" sejam eleitos como resultado de eleições limpas ${ }^{27}$. Ego tem que correr este risco porque está sancionado e respaldado pelo sistema legal de uma democracia política; isto é parte de que ego é um ser social rodeado de, e constituído por, direitos e deveres estabelecidos e respaldados - se fosse necessário, mediante a coerção - pelo estado ${ }^{28}$. Para ego, este é, entretanto, um risco moderado: sob um regime de eleições limpas e institucionalizadas há segurança de que em futuras rodadas dessas eleições terá possibilidades razoáveis de fazer com que sejam eleitos os candidatos que lhes pareçam adequados.

Encontramos outra característica específica da democracia política: é o único tipo de regime que resulta de uma aposta institucionalizada, universalista e inclusiva. Todos os outros regimes, que incluam ou não eleições, estabelecem algum tipo de restrição a esta aposta ou a suprimem por completo. Novos ou velhos, os regimes democráticos contemporâneos são resultado desta aposta e estão profundamente marcados por ela.

Posso agora incluir uma proposição:

3. Um regime democrático inclui eleições que são limpas e institucionalizadas, assim como uma aposta institucionalizada, inclusiva e universalista.

A esta altura convém lembrar que os cidadãos(ãs) de um estado que contém esse tipo de regime tem diversos direitos participativos, já comentados. Além disso, é lógico que, para que eles possam exercer esses direitos, o estado e seu sistema legal devem estabelecer e respaldar outros direitos (ou garantias), habitualmente considerados "políticos". A razão é que, para a institucionalização de eleições limpas - sobretudo na medida em que essa

\footnotetext{
${ }^{27}$ Em alguns países estes egos podem se constituir numa legião, inclusive se estão legalmente obrigados a aceitar a aposta. Em uma pesquisa que realizei na área metropolitana de São Paulo, Brasil, (Dezembro de 1991/Janeiro de 1992), um surpreendente 79\% respondeu "não" para a pergunta "Os brasileiros sabem votar?". Esta porcentagem chega a $84 \%$ entre os entrevistados com educação secundária e superior (no contexto era claro para os entrevistados que a pergunta não se referia aos mecanismos do voto, mas à sua avaliação das opções que outros eleitores faziam entre os partidos e os candidatos em disputa).

${ }^{28}$ Existe uma óbvia exceção ao que foi exposto anteriormente: quando as democracias emergem. Nestes casos, na medida em que são sancionadas por corpos constituintes claramente eleitos, ou ratificados por um referendo também limpo, os direitos e obrigações pertinentes podem ser considerados expressão de um acordo majoritário - e, portanto, suficiente - para a institucionalização da aposta democrática. Depois deste momento, as gerações sucessivas se encontram ab initio rodeadas de, e constituídas pelas relações, legalmente definidas, características do regime e da aposta democrática.
} 
institucionalização envolve expectativas de duração indefinida -, essas eleições não podem existir isoladamente. Algumas liberdades que rodeiam as eleições e - muito importante - que continuam regendo entre elas, devem existir também. De outro modo, o governo de turno poderia manipular com facilidade ou inclusive cancelar eleições futuras.

De acordo com um influente autor, Robert $\mathrm{Dahl}^{29}$, as liberdades políticas relevantes são as de expressão, associação e de acesso à informação plural; outros autores postulam, mais ou menos explicitamente e com maior ou menor detalhe, direitos similares. O mesmo que os direitos à participação, os que discuto neste momento são limitadamente universais, já que correspondem a quase todos os adultos, em e pelo sistema legal de um estado em que habitam e que contém um regime democrático ${ }^{30}$.

Embora complique o que foi dito até agora, devo observar que o efeito combinado das liberdades enunciadas por Dahl e outros autores não podem garantir inteiramente que as eleições sejam limpas e institucionalizadas. Por exemplo (levando em consideração liberdades usualmente omitidas nessas definições), o governo poderia proibir aos candidatos da oposição viajar dentro do país, ou submetê-los a perseguição policial por razões que pretenderia falsamente como independentes de suas candidaturas. Nesses casos, inclusive se as liberdades propostas por Dahl e outros autores fossem aplicadas, não seria razoável concluir que as eleições são limpas, menos ainda institucionalizadas. Isto significa que as condições propostas por Dahl e outros não são suficientes para garantir as eleições livres. Na verdade elas são condições necessárias que, conjuntamente, permitem um juízo probabilístico: se regem, então, ceteris paribus, existe boa probabilidade de que as eleições sejam limpas e institucionalizadas ${ }^{31}$.

Podemos discutir agora um problema que geralmente é ignorado pelas teorias contemporâneas da democracia, mas que tem relação próxima com outro tema do desenvolvimento humano e dos direitos humanos. Os direitos acima mencionados são derivados indutivamente. Seu listado resulta de uma fundamentada avaliação empírica de seu

\footnotetext{
${ }^{29}$ Ver Dahl (1989; 1999).

${ }^{30}$ Ter-se-á avisado que várias vezes falei de "um estado que contém um regime democrático". Este se deve a um argumento que apresento em O’Donnell (2000) e que por razões de espaço me refiro. Brevemente, digo, como é habitual, que "O país X é democrático" é uma enganadora metonímia (embora implicitamente reveladora do alto valor positivo atualmente atribuído para a democracia), enquanto designa o conjunto por um de seus atributos; esse mesmo país é também capitalista, localizado na região Y do mundo, mais ou menos desenvolvido ou desigual, etc. Tal como argumento no meu op. cit. e desenvolvo no meu próximo livro, é necessário rigor conceitual, não só por razões teóricas, mas também práticas, demanda precisões do tipo que implico na formulação que comento.

${ }^{31}$ Seguramente se observou que estou me referindo indistintamente a direitos e liberdades. Mais adiante precisarei este uso.
} 
impacto sobre a probabilidade de que existam eleições limpas e institucionalizadas ${ }^{32}$. Este juízo está controlado pela intenção de encontrar um núcleo mínimo, ou central, de liberdades, no sentido de que sua enumeração não se converta em um tão longo quanto inútil inventário de todos os direitos ou liberdades que podem ter relação com a limpeza e a institucionalização das eleições. O problema é que, posto que os critérios de inclusão de algumas liberdades e de exclusão de outras inevitavelmente é resultante de juízos indutivos, não pode existir uma teoria que estabeleça um critério firme e claro que determine o que chamarei um conjunto mínimo necessário dessas liberdades. No caso das liberdades políticas, esse conjunto, se existesse, incluiria somente as condições que são necessárias e - entre todas - suficientes para que existam eleições limpas e institucionalizadas; esse conjunto, portanto, excluiria outras liberdades que, mesmo que possam contribuir ao melhor desempenho desse tipo de eleição, não seriam condições necessárias ou suficientes para ele. Entretanto, como as liberdades a serem incluídas e excluídas no conjunto são derivadas indutivamente ${ }^{33}$, nunca haverá um acordo intersubjetivo firme e generalizado sobre qual seria seu conjunto mínimo suficiente: disputaremos eternamente quais são as liberdades que são "verdadeiramente" necessárias e conjuntamente suficientes para o exercício da cidadania política.

Até aqui discuti a questão dos limites externos das liberdades que rodeiam, e tornam prováveis, as eleições limpas e institucionalizadas; isto é, a questão de quais liberdades incluir e excluir deste conjunto. Mas existe outro problema: o dos limites internos de cada uma dessas liberdades. Todas elas contêm o que chamaria de uma cláusula de razoabilidade que, uma vez mais, fica normalmente implícita nas teorias da democracia ${ }^{34}$. Assim, por exemplo, a liberdade de formar associações não inclui criar organizações com fins terroristas; a liberdade de expressão é limitada, entre outras coisas, pelo delito de calúnia; a liberdade de informação não requer que a propriedade dos meios seja inteiramente competitiva, etc. Como determinar se estas liberdades são efetivas ou não? Certamente, os casos que caem próximos de algum dos extremos não apresentam problemas. Mas muitos outros caem em uma área cinzenta entre os dois pólos. Aqui uma resposta depende novamente de juízos indicativos sobre o grau no qual até a débil (ou parcial, ou intermitente) efetividade de certas liberdades suporta, ou não, a probabilidade de eleições livres e institucionalizadas. Uma vez mais, não existe uma resposta firme e clara para esta questão: os limites internos e externos dos direitos políticos são

\footnotetext{
${ }^{32}$ Obviamente, esta não é a única razão pela qual estes direitos são importantes. Volto a este assunto adiante.

${ }^{33}$ Esta é só uma razão para este enigma; mais tarde encontraremos outras.

${ }^{34}$ Em contraste, este tema tem gerado uma enorme literatura entre os juristas. Voltarei sobre alguns aspectos desta literatura e sua lamentável distância da maior parte da Ciência Política e da sociologia política.
} 
teoricamente indecidiveis ${ }^{35}$. Outro modo de dizer isto é afirmar que o que ele sobra é o conjunto mínimo suficiente dessas liberdades. Este fato, no entanto, não deve nos levar a negar que as liberdades que são razoáveis candidatas a pertencer a este conjunto são sumamente importantes, e que como tais devem ser levadas em cuidadosa consideração ${ }^{36}$.

Uma dificuldade adicional é que os limites internos de liberdades tais como as arroladas por Dahl, e de outros direitos e liberdades que são também potencialmente relevantes para a existência de eleições limpas e institucionalizadas, têm experimentado mudanças significativas ao longo do tempo. Basta notar que certas restrições à liberdade de expressão e de associação que nos países pioneiros se consideravam aceitáveis até não muito tempo, hoje seriam consideradas claramente antidemocráticas ${ }^{37}$. Tendo isto em conta, quão exigentes deveriam ser os critérios que aplicamos para as recém surgidas democracias (e a outras, mais antigas, fora do Noroeste)? Deveríamos aplicar os critérios atualmente vigentes nos países iniciadores ${ }^{38}$, ou os utilizados ali no passado, ou fazer em cada caso avaliações indutivas desses direitos em termos da probabilidade da realização de eleições limpas e institucionalizadas? Parece-me que esta última posição é a mais adequada, mas ela nos reenvia diretamente ao problema da indecidibilidade dos respectivos conjuntos de direitos, agora ainda mais complicados por sua variabilidade histórica.

Concluo que existe, e continuará existindo, divergência - na academia e, por certo, na política - a respeito de onde traçar os limites externos e internos das liberdades que rodeiam e fazem possíveis as eleições limpas e institucionalizadas. Isto não é um defeito das tentativas de enunciar estas liberdades. Elas são sumamente importantes, tanto em si mesmo como devido a sua relação com essas eleições: elas são condições necessárias para efetivar os direitos de participação postulados por um regime democrático, e como tais devem ser listadas. Por um lado, então, pode ser empiricamente estabelecido que a falta ou a limitação severa de algumas dessas liberdades (digamos, de expressão, associação ou movimento)

\footnotetext{
${ }^{35}$ Desde um ângulo diferente, mas convergente, me parece útil a discussão sobre a indecisão em Mouffe (1996; 2000). Pelo que sei, a origem deste termo se encontram na obra de Jacques Derrida, mas aqui o uso de maneira bastante diferente da utilizada por este autor. Por outro lado, por razões que espero estejam claras a seguir, não compartilho os comentários de Silveira no sentido de afirmar que esta indecisão necessariamente implica a subscrever teorias que são "puramente culturalistas" ou que "reduzem os direitos da lógica do interesse".

${ }^{36}$ Veremos que existe é uma dupla dimensão nisto. Por um lado, em um nível individual, estes são direitos universalisticamente atribuídos; por outro lado, em um nível macro, estas são liberdades que caracterizam e coconstituem o contexto social no qual estes indivíduos estão imersos.

${ }^{37}$ Por exemplo, Holmes e Sustein (1999, p. 104) observam que "lo que la libertad de palabra significa para la jurisprudencia americana (sic) contemporánea no es lo que significaba cincuenta o cien años atrás”.

${ }^{38}$ Entre os quais, ademais, persistem até hoje diferenças significativas em relação com o alcance de alguns desses direitos.
} 
elimina a possibilidade de eleições limpas e, a fortiori, de sua institucionalização ${ }^{39}$. Por outro lado, o caráter indutivo destas listas e o problema conexo de seus limites externos e internos mostra suas limitações como proposições teóricas. Consequentemente, em lugar de ignorar estes problemas ou de tratar artificialmente de fixar os limites externos e internos destas liberdades, uma via mais fértil de indagação consiste em tematizar teoricamente as razões e implicações deste enigma ${ }^{40}$. Estamos em um terreno que suponho familiar para quem tem refletido sobre o desenvolvimento humano e os direitos humanos em termos de tentativas de encontrar conjuntos mínimos suficientes para seus respectivos interesses. Não são esses, em troca, temas que muitas vezes ocupam as principais correntes de Ciência Política contemporânea.

Após essa discussão pode ser útil listar algumas proposições:

4. Além das características observadas na proposição 3, um regime democrático consiste de algumas liberdades "politicas" (limitadamente) universalistas. Estas liberdades devem ser enumeradas porque são importantes per se porque são condições necessárias para a existência de eleições limpas e institucionalizadas, e, portanto, para a contínua efetividade da aposta democrática.

5. Entretanto, tendo em vista que os limites externos e internos dessas liberdades são indecidiveis, não existe critério válido para deixar claro e estabelecer firmemente um conjunto mínimo suficiente desses direitos que tenham validade teórica elou intersubjetiva geral.

Aponto agora outras conclusões a que temos implicitamente chegado por meio da discussão precedente. Uma é a definição de cidadania política como o componente individual de um regime democrático. Ela consiste na atribuição dos direitos vinculados à aposta democrática, isto é, tanto de algumas liberdades "circundantes" (tais como as de expressão, associação, informação, livre movimento e outras deste tipo) como dos direitos de participação em eleições limpas e institucionalizadas, inclusive o direito de votar e ser eleito(a).

A segunda conclusão é que esta definição nos tem levado mais adiante do regime e nos tem adentrado no estado, em dois sentidos. Primeiro como a entidade territorial que delimita aos portadores dos direitos e obrigações da cidadania política e, segundo, como um

\footnotetext{
${ }^{39}$ Por sua vez, obviamente segundo o que já foi fundamentado, neste caso, embora haja eleições, o regime não seria democrático.

${ }^{40}$ Em um contexto similar (conceitos de igualdade), Amartya Sen (1993, p. 33-34) assinala bem: "Sin una idea fundamental tiene una esencial ambigüedad, una formulación precisa de esa idea debe tratar de capturar esa ambigüedad más que ocultarla o eliminarla" (itálicos no original).
} 
sistema legal que sanciona e respalda esses mesmos direitos e obrigações. Isto me permite formular outra proposição.

6. A aposta democrática e a cidadania política são, respectivamente, as caras coletiva e individual da mesma moeda - o regime democrático - e ambas pressupõem o estado, tanto como uma delimitação territorial quanto como um sistema legal (que, além disso, deve ser realizado por diversas burocracias que se desempenham em consonância com o mesmo).

Os aspectos do estado recém apontados têm uma dupla função: em um sentido, eles são condições necessárias para a existência de um regime democrático; em outro - o que discuto a seguir - são características do caráter democrático do próprio estado, não somente do regime.

Incluo agora outras proposições:

7. A cidadania política consiste da atribuição universal (embora territorialmente delimitada) dos direitos e liberdades vinculados a uma aposta democrática inclusiva, ou seja, tanto de algumas liberdades circundantes quanto dos direitos à participação em eleições limpas e institucionalizadas, incluindo votar e ser eleito $(a)$.

8. Um regime democrático (ou democracia política, ou poliarquia) pressupõe: a. Um estado de base territorial que delimita quem são considerados cidadãos(ãs) políticos(as); e b. Um sistema legal desse mesmo estado que, dentro de seu território, atribui a cidadania politica sobre bases (limitadamente) universalistas.

\section{Primeiro excurso sobre a Qualidade da Democracia}

A presente digressão, assim como as que seguem, tem estreita relação com o valioso trabalho realizado pela equipe do projeto "Estado da Nação" da Costa Rica, especialmente com sua Auditoria cidadã sobre a qualidade da democracia (2001). Isto não se dá por acaso, já que como comento no começo deste capítulo, em várias ocasiões discuti em detalhe estas questões, assim como seus fundamentos teóricos e metodológicos, com os autores deste trabalho e recebi inspiração do mesmo. A premissa da Auditoria, assim como a do que segue, é que a qualidade da democracia de determinados países pode ser avaliada pelos diferentes 
graus de democraticidade em uma série de dimensões ${ }^{41}$. Nesta digressão me limito às dimensões diretamente implicadas no que discuti até aqui ${ }^{42}$. Irei agregando outras dimensões na medida em que analiso outros temas.

A fim de ordenar minhas sugestões sobre esta questão, apresento sequencialmente vários processos típicos, sobre os quais queremos saber:

\section{V.1. Antes de eleições limpas e institucionalizadas}

\section{V.1.1. Sobre os cidadãos(ãs).}

V.1.1.1. Quantos possuem uma preferência clara e presumivelmente estável por um regime democrático em lugar de qualquer outro.

V.1.1.2. Quantos aceitam que a população territorialmente limitada pelo estado em que vivem é a unidade que determina a definição do eleitorado.

V.1.1.3. O quanto estão informados sobre os partidos, candidatos e temas de cada eleição.

V.1.1.4. O quanto estão interessados sobre estes temas.

V.1.1.5. Quanto e de que maneira participam de atividades políticas, especialmente as relacionadas com eleições.

V.1.1.6. Se o quanto usam das oportunidades existentes para expressar opiniões sobre a discussão, decisão ou implementação de políticas públicas.

\section{V.1.2. Sobre o sistema eleitoral}

V.1.2.1. Se existe uma comissão ou tribunal eleitoral independente, imparcial e adequadamente investido de autoridade e recursos como para garantir a idoneidade das eleições, tanto em nível nacional quanto sub-nacional.

V.1.2.2. Se o sistema eleitoral não sobrerrepresenta certos distritos ou certos tipos de eleitores e, se esse é o caso, em que medida.

V.1.2.3. Se compensa significativamente as desvantagens que certos partidos possam sofrer pelo fato de não serem apoiados por grupos economicamente poderosos.

\footnotetext{
${ }^{41}$ Concordo com os comentários de Coppedge, no sentido que convém considerar estas dimensões como variáveis, das quais um quer analisar seu grau de presença ou peso em cada caso. Concordo também com Coppedge e como os comentários de Mazzuca e Munck, que argumentam que o anterior é um passo fundamental para poder explorar empiricamente as relações entre as ditas variáveis. Faço este esclarecimento porque a redação original do presente texto parece ter induzido estes colegas a acreditarem erroneamente que não concordo com o que foi dito acima.

${ }^{42}$ A Auditoria fez um trabalho sumamente cuidadoso e útil ao caracterizar estes e outros itens como padrões e explicar as razões deste critério. Para detalhes, devo me referir a este texto e ao preparado por Vargas Cullell et. al. (O'DONNELL, IAZZETTA, CULLELL, 2003).
} 
V.1.2.4. Se existem regras claras e aplicáveis para a publicidade das contribuições que os partidos políticos recebem para as campanhas eleitorais e para o seu funcionamento.

V.1.2.5. Se não se colocam altas barreiras para a criação e o desempenho dos partidos políticos, com exceção dos que advogam pelo uso de meios violentos para a competição política e/ou para ascender a posições governamentais.

V.1.2.6. Se não existem requisitos complicados para o registro dos eleitores, e especialmente os que podem ser difíceis de cumprir por indivíduos pobres e/ou discriminados(as).

V.1.2.7. Se os(as) cidadãos(ãs) são livres para filiar-se a um partido, para tratar de ser selecionado como candidatos(as) do mesmo e, se o são, para apresentarem-se a eleições.

V.1.2.8. Se todos os partidos e candidatos(as) são tratados respeitosa e imparcialmente pelas autoridades governamentais.

V.1.2.9. Se as eleições nacionais são realizadas com frequência suficiente como para refletir importantes mudanças na opinião pública, e se existem mecanismos legais que permitam aos cidadãos, com devidas precauções para evitar decisões minoritárias e/ou apressadas, remover os funcionários eleitos, se o consideram necessário, entre eleições ${ }^{43}$.

\section{V.1.3. Sobre os partidos políticos.}

V.1.3.1. Se seus procedimentos internos, especialmente em matéria de designação de suas autoridades e candidatos, são abertos à participação e controle de seus filiados e das instituições estatais pertinentes.

V.1.3.2. Se publicizam, no devido tempo e forma, o apoio público e privado que recebem, e prestam conta do uso que fazem deste apoio.

V.1.3.3. Se conduzem suas campanhas eleitorais respeitando os direitos civis e políticos de seus oponentes, e de maneira que não envolva nem promova discriminação, calúnia ou qualquer outra forma de intolerância.

V.1.3.4. Se existem incentivos para facilitar ou promover a participação política de setores cidadãos(ãs) pobres e/ou discriminados(as) ${ }^{44}$.

\section{V.2. Sobre as eleições}

V.2.1. Se os(as) votantes não são intimidados(as) ou pressionados(as) de qualquer forma, e se seus votos são verdadeiramente secretos.

\footnotetext{
${ }^{43}$ Tomo esta cláusula, com pequenas modificações, dos comentários de Coppedge.

${ }^{44}$ Tomo este item dos comentários de Karl.
} 
V.2.2. Se existe livre acesso aos locais de votação e escrutínio para os(as) eleitores, representantes de partidos, observadores da eleição e meios de comunicação.

V.2.3. Se as eleições se desenvolvem de maneira ordenada e pacífica.

V.2.4. Se os votos são contados imparcialmente e os resultados anunciados sem demora.

V.2.5. Se os(as) ganhadores(as) dos pleitos são proclamados(as) como tais e no momento devido assumem suas respectivas posições governamentais.

V.2.6 Se as queixas ou impugnações sobre as eleições são tratadas com imparcialidade e rapidez.

V.2.7 Se os resultados da eleição são aceitos como válidos pela população em seu conjunto.

\section{V.3. Sobre o governo eleito}

\section{V.3.1. O Executivo}

V.3.1.1. Se atua com clareza e consistência acerca dos direitos dos cidadãos(ãs) e suas associações, assim como da autoridade e jurisdição de outras instituições estatais V.3.2. O Congresso

V.3.1.1. Se atua com claro e consistente respeito aos direitos dos cidadãos(ãs) e a suas associações, assim como da autoridade e jurisdição de outras instituições estatais.

V.3.2.2. Se conduz suas deliberações e tomadas de decisões de maneira que respeitem razoavelmente o direito de cada legislador(a) a ser ouvido(a) (em sessões plenárias e/ou em comissões) e a que seu voto seja contado em igualdade de condições com os outros.

V.3.2.3. Se os partidos minoritários têm possibilidade razoável de que suas críticas e propostas sejam consideradas e discutidas, dentro e fora do Congresso.

V.3.3. O funcionamento geral do governo

V.3.3.1. Se atua com claro e consistente respeito pelos direitos dos(as) cidadãos(ãs) e de suas associações, assim como da autoridade e jurisdição de outras instituições estatais.

V.3.3.2. Se oferece aos(as) cidadãos(ãs) e a suas associações oportunidades claras, oportunas e factíveis de expressar suas opiniões sobre a discussão, a decisão e implementação de políticas públicas.

Apresso-me a comentar que esta é, por assim dizer, uma lista inocente. Uma razão é que ignora algumas situações complicadas. A lista, com efeito, tem preferência por valorizar positivamente as oportunidades de participação cidadã. Entretanto, em certas áreas de políticas 
públicas (por exemplo, decisões sobre tipo de mudança) podem haver sólidas razões para evitar essa participação; ou em outras áreas (por exemplo, negociações de relações exteriores ou e em alguns assuntos de segurança nacional) pode se justificar a necessidade do segredo. Nestes casos o teste de democraticidade relativa deveria se centrar sobre o tipo de procedimentos e atores envolvidos no estabelecimento destas limitações ${ }^{45}$, assim como na existência ou não de possibilidades de desafiá-las e, no caso, anulá-las.

A segunda razão da inocência da lista precedente é que passa por alto a questão de se um sistema eleitoral é de melhor qualidade, ou mais democrático, segundo se incline por um sistema de representação majoritária ou por um de representação proporcional. Alguns indivíduos que, de acordo com qualquer teste que possamos aplicar, são solidamente democráticos, tenderão a preferir a proporcionalidade se tem convicções firmemente liberais; outros, em troca, preferirão um sistema de representação majoritária, se participam de visões derivadas da democracia clássica ou do republicanismo ${ }^{46}$. Rigorosamente, este é outro tema indecidível. Supondo que o eleitorado está dividido sobre este assunto, a solução naturalmente democrática seria que a questão se decida por meio do voto. Mas a votação deve se realizar de acordo com uma ou outra destas regras, com o que a questão estaria decidida de antemão; por outro lado, caso se faça mediante um referendum então a questão também teria sido prédecidida, neste caso em favor dos propiciadores de um sistema majoritário. Esta pode ser uma das razões pelas quais frequentemente encontramos regimes eleitorais híbridos que combinam, às vezes de maneira bastante desajeitada, regras majoritárias e proporcionais. Em vista disso, creio que uma evolução da qualidade da democracia deve se abster de julgar sobre esta questão $^{47}$.

Por último, pode ter-se percebido algumas omissões na lista precedente: não se ocupa de alguns importantes aspectos do formato institucional das democracias, especialmente de regimes federal ou unitário, ou presidencialista ou parlamentarista (e das diferentes combinações entre eles), como assim, tão pouco, da contraposição entre sistemas de revisão jurídica e de cortes constitucionais. A razão é que, no presente estado de nosso conhecimento, não me parece que qualquer dessas variantes possa ser considerada como mais ou menos democrática que a outra; de outro lado, qualquer que seja a adotada em cada caso, ela pode ser avaliada em termos dos itens listados aqui e nas próximas digressões.

\footnotetext{
${ }^{45}$ Por exemplo, se o executivo pode ou não decidir unilateralmente este tipo de questão e em que áreas.

${ }^{46}$ Para explicação e discussão destes termos, remeto a O’Donnell (1998; 2001a).

${ }^{47}$ Em seus comentários, Tavares de Almeida concorda, afirmando que "Desde el punto de vista de la calidad de la democracia no hay manera de decidir entre, por ejemplo, el modelo de Westminster de fusión de poderes o el modelo de separación de poderes y de checks and balances". Em seus comentários Coppedge discorda, argumentando que quanto mais proporcional (ou seja, anti-majoritário) um sistema eleitoral, mais democrático - não estou convencido.
} 


\section{Democracia e Agência}

A análise precedente do regime é descritiva. A partir desta seção ingressamos em um terreno onde necessitarei fazer afirmações normativas, não só factuais ${ }^{48}$. Em particular, o tema da concepção do ser humano como um agente requer não só formulações descritivas, mas também extrair as consequências normativas de sua efetividade e também - especialmente no caso da América Latina - de sua não efetividade.

Começo por lembrar que a aposta democrática implica na atribuição universalista do direito de eleger, ser eleito e exercer as liberdades "políticas" que circundam o regime. Tenhamos agora um olhar mais cuidadoso sobre a cidadania política. É um status legalmente definido reservado, como parte e consequência da aposta democrática, para a maioria dos habitantes de um estado que contém um regime de eleições limpas e institucionalizadas. Este status é misto. É adscritivo no sentido que (exceto em casos de naturalização) pertence aos indivíduos pelo simples fato de ter nascido em um determinado território (ius solis) ou de certa linhagem (ius sanguinis). É, como já vimos, limitadamente universalista, já que é atribuído, dentro da jurisdição delimitada por um estado, a todos os adultos que compartilham a mesma nacionalidade. É também um status formal, já que resulta de regras legais que em seu conteúdo, promulgação e adjudicação satisfazem certos critérios que são especificados por outras regras legais, algumas delas de nível constitucional. Além disso, a cidadania política é pública $^{49}$. Com isto quer dizer, primeiro, que é o resultado de leis que satisfazem requisitos de publicidade cuidadosamente regulados e, segundo, que os direitos e obrigações que atribui a cada um implicam, e legalmente demandam, um sistema de reconhecimento recíproco entre todos os indivíduos, independentemente de suas posições sociais, como portadores desses direitos e ou obrigações ${ }^{50}$. Por último, a cidadania política é igualitária: gera um espaço de igualdade legalmente estabelecida na atribuição (e de seu exercício ao menos potencial) de uma série de direitos.

Volto agora para a aposta democrática. Seu caráter inclusivo é uma conquista recente. Por um longo tempo, nos países pioneiros diversos setores sociais foram excluídos do direito de votar, e menos ainda de serem votados: campesinos, trabalhadores manuais, trabalhadores domésticos (e, em geral, não proprietários e indivíduos pouco educados), negros nos Estados Unidos, índios nesse mesmo país e muitos outros e, por certo, mulheres. Só durante o século

\footnotetext{
${ }^{48}$ Sobre essa distinção ver os comentários de Mazzuca; mas vários dos temas que este autor trata vão bastante além das possibilidades deste texto.

${ }^{49}$ Para uma discussão útil das várias dimensões da publicidade em democracia, ver Iazzetta (2002).

${ }^{50}$ Lembremos que não depende da vontade ou preferências subjetivas do ego ter que reconhecer que todo alter tem, em um contexto de um regime democrático, os mesmos direitos e obrigações que ele.
} 
XX - em não muitos países, somente depois da Primeira Guerra Mundial - os direitos políticos tornaram-se inclusivos ${ }^{51}$. Da sua parte, em diversas ocasiões os países no Sul e no Leste adotaram o sufrágio inclusivo; mas diferentes tipos de democracia "tutelares" que emergiram neles, ou de regimes abertamente autoritários, significaram o rechaço da aposta democrática.

Em todas as partes, a história da democracia é a história da renitente aceitação do desafio da inclusão - quer dizer, da rejeição a aceitar a universalização da atribuição de agência no domínio do político. A história dos países pioneiros está marcada pelas catastróficas predições ${ }^{52} \mathrm{e}$ às vezes a violenta resistência ${ }^{53}$ de setores e classes dominantes que se opuseram à extensão dos direitos políticos a outras classes e setores, considerados "indignos" ou "pouco confiáveis". Em outras latitudes, por meios às vezes ainda mais violentos e excludentes, esta extensão também sofreu resistência. Quais foram as razões dessa rejeição? Tipicamente, um argumento de falta de autonomia e de responsabilidade dos excluidos; ou seja, a negação de sua condição de agentes. Argumentava-se que somente alguns indivíduos (altamente educados e/ou proprietários, ou uma vanguarda política que decifrou a direção da história, ou uma junta militar que entendia as demandas da segurança nacional, ou uma teocracia) teriam capacidades morais e cognitivas suficientes para participar ativamente da vida política. Somente eles eram vistos como suficientemente dotados (em termos de educação, propriedade, trabalho revolucionário, desígnios patrióticos ou conhecimento da verdadeira religião) de conhecimentos e motivação adequados para a tomada responsável de decisões coletivas. É claro, as vanguardas revolucionárias, as juntas militares e as teocracias geraram regimes autoritários, enquanto que nos países iniciadores os privilegiados geraram, ou na maioria dos casos e não sem, às vezes, brutais interrupções autoritárias, regimes oligárquicos (ou seja, democracias políticas não inclusivas) para eles e exclusão política para o resto.

\footnotetext{
${ }^{51}$ Em que pese frequentes informações ao contrário, nem sequer em termos de sufrágio universal masculino os Estados Unidos são exceção a isso. A existência recente deste sufrágio em nível federal foi convertida em puramente nominal pelas severas restrições impostas sobre os negros e índios, especialmente no Sul. Devido a isto, o ganho neste país de uma democracia política inclusiva deve ser datado da Segunda Guerra Mundial ou inclusive em uma época tardia como a década de 1960, como resultado do movimento dos direitos civis.

${ }^{52}$ Ver, sobre essas resistências, Hirschman (1991) e Rosanvallon (1992). Como disse um político britânico que se opunha à Ata da Reforma de 1867, "Como soy un liberal [...] observo como uno de los mayores peligros la propuesta [...] de transferir poder de las manos de la propiedad y la inteligencia a las manos de hombres cuya vida entera está necesariamente ocupada en la lucha cotidiana por la existencia" (LOWE apud HIRSCHMAN, 1991, p. 94).

${ }^{53}$ Ver principalmente Goldstein (1983).
} 
Como vimos, existe uma idéia central subjacente a este tópico: a agência. Um agente é alguém dotado de razão prática: usa sua capacidade cognitiva e motivacional para decidir opções que são razoáveis em termos de sua situação e de suas metas, sobre as quais, salvo prova terminantemente contrária, é considerado o(a) melhor juiz(a) ${ }^{54}$. Esta capacidade faz dele(a) um(a) agente moral, no sentido de que normalmente se sentirá (e será considerado(a) pelos outros) responsável por suas opções e (ao menos) pelas consequências que seguem diretamente delas.

Claro, os autores que desde diversos ângulos se ocupam deste tema oferecem várias objeções e ressalvas ao que acabo de afirmar. Entretanto, destaco que, sem prejuízo do que foi dito, a presunção de agência é outro fato que, nos países pioneiros, é mais antigo e foi institucionalizado antes da aposta democrática e das eleições limpas. Esta presunção não é somente um conceito moral, filosófico ou psicológico: é um conceito legalmente sancionado $e$ respaldado. A presunção de agência é, precisamente, o que constitui a cada indivíduo como uma pessoa legal, portadora de direitos subjetivos. Essa pessoa realiza opções, e é responsabilizada por elas, porque o sistema legal pressupõe que seja autônoma, responsável e razoável - é, repito, um agente ${ }^{55}$.

Esse critério se tornou o coração dos sistemas legais dos países iniciadores muito antes que democracia política. O reconhecimento institucionalizado (ou seja, legalmente sancionado e respaldado e, sociologicamente, amplamente compartilhado) de um agente portador de direitos subjetivos ocorreu ao longo de um complexo processo que se iniciou com alguns sofistas, estóicos e Cícero, continuou através da adoção do direito romano e dos jurisconsultos medievais ${ }^{56}$, foi refinado pelos teóricos da lei natural e foi finalmente reapropriado e, diria, politizado, apesar de suas diferenças sobre outras questões, pelos grandes pensadores do início do liberalismo - especialmente Hobbes, Locke e Kant -, assim como por um não-liberal, Rousseau.

\footnotetext{
${ }^{54}$ Como diz Dahl (1989, p. 108), "la carga de la prueba [da falta de agência] corresponde siempre a quien reclama una excepción, y ninguna excepción será admisible, ni moral ni legalmente en ausencia de una demonstración concluyente". De fato, este princípio foi formulado pela primeira vez, em termos muito similares aos que Dahl utiliza, por John Stuart Mill (1962, p. 206 e passim).

${ }^{55}$ Jeremy Waldron (1992, p. 282) comenta que: "La identificación de alguien como portador de derechos expresa una medida de la confianza en las capacidades morales de esa persona - en particular, en su capacidad para pensar responsablemente sobre la relación moral entre sus intereses y los intereses de otros".

${ }^{56}$ Foi particularmente importante o redescobrimento, no século XI, dos Códigos Justinianos. Como observa Berman (1993, p. 245), parte de sua importância se deve ao fato de que o direito romano "había alcanzado un muy alto nivel de sofisticación en el terreno de los contratos". Desde uma perspectiva teórica diferente, Anderson (1974) concorda, agregando que as concepções legais romanas sobre livre disposição da propriedade imobiliária foram também fundamentais.
} 
Não posso referir aqui a esta história ${ }^{57}$. Basta observar que se trata da história da formulação e progressiva expansão de uma visão não só moral, mas também legal do indivíduo como portador de direitos subjetivos; esses são direitos que pertencem a cada indivíduo como tal, não como derivação (como em Aristóteles, São Tomás e outras teorias organicistas) da posição que ocupa em uma hierarquia social. Esses direitos sublinham o que as teorias clássicas chamavam de potestas de cada indivíduo, sua capacidade para assumir voluntária, responsável e livremente obrigações e, correlativamente, seu direito a demandar o cumprimento das obrigações da(s) contraparte(s). Historicamente, esta concepção encontrou sua expressão máxima na lei de contratos e na mercantilização da propriedade da terra ${ }^{58}$. Esses processos tiveram lugar em contraponto com a expansão, nos países pioneiros, do capitalismo e do estado moderno. Por um lado, o agente que contrata validamente é o mesmo que vende "livremente" sua força de trabalho ao capitalista. Por outro lado, a atribuição formalmente igualadora de agência nas áreas do contrato e da propriedade sob uma jurisdição legal comum, foi um poderoso instrumento nas lutas dos formadores de estados (state makers) contra os poderes feudais, as autonomias urbanas, as corporações medievais e a Igreja Católica ${ }^{59}$. Até que os grandes pensadores liberais começaram a transpor essa idéia de agência ao plano político, os recém referidos ficaram basicamente limitados aos chamados direitos civis, referidos a relações "privadas" entre os indivíduos. Além disso, os direitos não foram estendidos universalmente: entre outros, aos trabalhadores, camponeses e mulheres não poucos desses direitos lhes foram estendidos mais lentamente e de forma restrita.

Entretanto, os fatos fundamentais para a minha discussão são os seguintes: primeiro, a atribuição legal de agência a um número crescente de indivíduos tem uma grande história nos países pioneiros; segundo, essa atribuição teve elaboração detalhada em diversas doutrinas filosóficas, morais e - especialmente - legais, antes que os grandes teóricos liberais transpusessem essa idéia de agência ao campo político ${ }^{60}$; terceiro, mais tarde esta mesma perspectiva inspirou duas grandes constituições modernas: a da França e a dos Estados Unidos. Insiro agora uma proposição:

\footnotetext{
${ }^{57}$ A fim de não estender o presente texto, remeto novamente a O’Donnell (2000).

${ }^{58}$ Sobre o tema ver, especialmente, Hamburguer (1989).

${ }^{59}$ Ver sobre essas questões o clássico trabalho de Weber (1968).

${ }^{60}$ Pierre Rosanvallon (1992, p. 111) comenta que antes do surgimento do liberalismo "esta perspectiva de la autonomía de la voluntad ciertamente apareció ya jurídicamente formulada en el derecho civil". Isto, por sua vez, foi parte de uma série de mudanças na própria concepção da moralidade; como observa Schneewing (1998, p. 27), "durante los siglos XVII e XVIII las concepciones de la moralidad entendida como obediencia vinieron a ser cada vez más rechazadas por concepciones emergentes de la moralidad entendida como auto-gobierno [...] centradas en la creencia de que todos los individuos normales son igualmente capaces de vivir juntos en una moralidad del auto-gobierno".
} 
9. No Noroeste, a concepção do indivíduo como um agente teve, muito antes da extensão universalista da cidadania política, um longo processo de elaboração em diversas doutrinas religiosas, éticas e filosóficas. Esta mesma concepção foi cuidadosamente elaborada e progressivamente implantada, no ritmo da expansão do capitalismo e do estado moderno, como uma doutrina legal que, atribuindo direitos subjetivos a um crescente número de indivíduos, lhes atribuiu, legal e universalmente, condição de agentes.

Contudo, como muitos comentaram, esta construção de um agente portador de direitos subjetivos, como omitia as condições reais de seu exercício, contribuiu para reproduzir relações sumamente desiguais, especialmente entre capitalistas e trabalhadores ${ }^{61}$. Mas, esta construção continha corolários explosivos. Em primeiro lugar, se a cada um se atribuí agência em certas esferas de sua vida, que são para ele(a) - e, no fim das contas, para o conjunto da sociedade - muito importantes (como o contrato de trabalho ou a compra e venda de bens imóveis), por que lhe seria negada esta mesma atribuição de agência em outras esferas da vida social e política, e, em todo caso, quem teria autoridade para decidir essa questão? Um segundo corolário se revelou não menos explosivo: posto que a condição de agente obviamente envolve a possibilidade de optar, que opções reais seriam razoavelmente compatíveis com a condição de cada um como tal agente?

A resposta para a primeira pergunta é a história da expansão posterior dos direitos subjetivos, incluindo o direito ao sufrágio até alcançar seu atual caráter inclusivo. Essa história foi escrita através de múltiplos conflitos ao cabo dos quais, depois de aceitar morrer maciçamente na guerra e trocado a revolução pelo Estado de Bem-Estar, as classes dangereuses foram finalmente admitidas na aposta democrática. Esses atores ganharam então sua cidadania política ${ }^{62}$. Enquanto isso ocorria, nos países pioneiros também se desenvolveram

\footnotetext{
61 "El resultado de la libertad contractual, entonces, es en primer lugar la apertura de la oportunidad de usar estos recursos sin restricciones legales, a través de una utilización inteligente de la propiedad en el mercado, como medio para alcanzar poder sobre otros. Las partes interesadas en el poder en el mercado están pues también interesadas en un orden legal compatible [...]. La coerción es ejercida fuertemente por los propietarios de los medios de producción y adquisición, a quienes la ley garantiza su propiedad [...] En el mercado de trabajo, se deja a la "libre" decisión de las partes aceptar las condiciones impuestas por los que son económicamente más fuertes en virtud de la garantía legal de su propiedad". O autor destas linhas é Weber (1968, p. 730-731), não Marx.

${ }^{62}$ Não sem que, adicionalmente, as classes e setores dominantes tenham empreendido vigorosos esforços educativos para se assegurarem de que os novos atores tenham se convertido em "cidadãos confiáveis". Esses esforços tiveram em longo prazo importantes efeitos democratizadores, mas para uma discussão de seu caráter inicialmente defensivo na França (onde não foi muito diferente de outros países iniciadores), ver Rosanvallon
} 
outros processos. Um foi que o mapa da Europa Ocidental ficou firmemente demarcado, como consequência de sucessivos, e correntemente cruéis, esforços por construir estados nacionais ${ }^{63}$. Outro foi a posterior expansão de direitos na esfera civil, no duplo sentido de que alguns direitos e obrigações já reconhecidos foram crescentemente especificados e expandidos a outros atores sociais, e de que novos direitos foram agregados ${ }^{64}$. Esses processos significaram que, se ao longo dos séculos XIX a maior parte dos países do Noroeste foram adotando sistemas democráticos oligárquicos, ao mesmo tempo uma grande proporção de sua população masculina (e, até certo ponto, feminina) conquistou uma ampla, e crescente, gama de direitos subjetivos que passaram a regular numerosas partes de suas vidas. Não se tratava, todavia, dos direitos participativos próprios da aposta democrática. Aqueles eram direitos civis, referidos a atividades sociais e econômicas "privadas". Esses direitos definem o que T. H. Marshall chamou de "cidadania civil""65.

Quero salientar que, quando a plena inclusão política se converteu em uma importante questão, nos países pioneiros já existia um rico repertório de critérios legalmente estabelecidos e elaborados sobre a atribuição de agência a um vasto número de indivíduos. Na verdade, o alcance desses direitos era, para nossos critérios contemporâneos, limitado. Mas também é certo que, nos países pioneiros, a cidadania civil precedeu a cidadania política e lhe forneceu uma rica textura de apoio. Esses mesmos processos ofereceram o sustento histórico da idéia central do liberalismo: o governo e o estado devem ser limitados e constitucionalmente regulados porque eles existem para, e em nome de, indivíduos que são portadores de direitos

(1992). A este respeito é significativa a grande atenção que Condorcet, Locke, Rousseau, Adam Smith e outros grandes expoentes do Iluminismo prestaram para a educação como um meio crucial para produzir agentes políticos "responsáveis".

${ }^{63}$ Sobre o tema ver especialmente Tilly (1985; 1990).

${ }^{64}$ Como disse Tilly (1994, p. 7) em relação à França, "Con la Revolución, virtualmente todo el pueblo francés adquirió acceso a las cortes del estado. Durante el siglo XIX, los derechos [...] se expandieron, junto con las obligaciones de asistir a la escuela, servir en el ejército, responder a los censos, pagar impuestos individualmente determinados y cumplir con otras obligaciones, de nuevo tipo, de los ciudadanos". Em relação à Inglaterra, Marshall (1964, p. 78) observa que até 1830 "los derechos civiles asociados al estatuto de la libertad habían adquirido ya sustancia suficiente como para permitirnos hablar de un estatus generalizado de ciudadanía [civil]". Isto também ocorreu, um pouco mais cedo ou mais tarde, nos outros países iniciadores.

${ }^{65}$ Como observou Marshall (1964, p. 18), "la historia de los derechos civiles en su período de formación es una historia de adición gradual de nuevos derechos a un estatus que ya existía y que se consideraba atributo de todos los miembros adultos de la comunidad". Este direitos civis são, na clássica definição deste autor, "los derechos necesarios para la libertad individual: libertad personal, libertad de palabra, pensamiento y credo, derecho a tener propiedades y suscribir contratos, y derecho a la justicia" (Ibid., p. 10-11). 
subjetivos sancionados e respaldados pelo mesmo sistema legal ao qual o estado e o governo devem obedecer e do qual derivam sua autoridade ${ }^{66}$. Insiro agora outra proposição:

10. Depois de uma longa e complexa trajetória histórica, nos países pioneiros - em geral e não sem abruptas interrupções - ocorreu a extensão bastante ampla de uma (majoritariamente masculina) cidadania civil, baseada na atribuição legal de agências nessa esfera. Esta foi a base, legal e sociológica, de um desenvolvimento posterior, a democracia política, centrada na cidadania politica. Esta por sua vez se baseou em uma concepção de agência já desenvolvida nesses países no terreno dos direitos civis.

Derivado do que foi dito anteriormente, em alguns países esta concepção dos indivíduos como agentes se ajusta muito bem a sua experiência histórica. Em outros países, em troca, os direitos civis nunca foram efetivos para amplas camadas da população. Discuto esta questão mais adiante, embora antecipe que ela tem importantes consequências. Algumas democracias podem ser concebidas como tendo um conjunto de direitos políticos que estão rodeados, sustentados e reforçados por uma densa rede de direitos civis. Outras democracias, por outro lado, exibem (por definição de um regime democrático) esses direitos políticos, mas o tecido de direitos civis é tênue e/ou desigualmente distribuído entre diferentes tipos de indivíduos, categorias sociais e regiões. Parece-me óbvio que as diferenças nessas dimensões - de caso a caso e ao longo do tempo - tem forte relação com a qualidade da democracia em cada caso e período.

Indiquei que, ainda quando inicialmente restringida aos direitos civis, a idéia do indivíduo como agente tem explosivas potencialidades. Em particular, um tema bastante óbvio que surge da presunção de agência se refere ao campo de opções que está realmente ao alcance de cada indivíduo ${ }^{67}$. Nos países pioneiros, as respostas a esta questão se abriram em duas direções. Uma colocou ênfase especialmente nos direitos civis, embora não exclusivamente, no que em geral podemos chamar a área do contrato. Se formularam então critérios legais para evitar, remediar ou prevenir situações nas quais existe uma relação "manifestamente desproporcional" ${ }^{68}$ entre as partes e/ou nas quais uma delas - devido à

\footnotetext{
${ }^{66}$ Jones (1994, p. 88) bem disse que: "La autoridad política es una autoridad ejercida sobre, y en nombre de, individuos con derechos".

${ }^{67}$ Adiante, quando me refiro a "opções" me refiro, salvo quando indicado o contrário, tanto à possibilidade subjetiva de exercer a razão prática fazendo opções razoavelmente autônomas e sábias, como o campo de opções objetivas com que o indivíduo realmente se encontra. Para uma útil discussão deste tema, ver, além das obras já citadas de Sen, Raz (1986).

${ }^{68}$ Como estabelece a Seção 138 do Código Civil alemão.
} 
compulsão, fraude, incapacidade mental, etc. - não pode ser considerada como tendo dado consentimento autônomo ao contrato ou outro tipo de relação supostamente consensual. Estas medidas tutelares se fixam sobre um critério básico de equidade, que por sua parte é um corolário da idéia dos indivíduos como agentes: se supõe que esses devem se relacionar com outros agentes como tais; isto é e, sem sofrer - pela razão que seja - perda de capacidades básicas (um tema central do desenvolvimento humano, nota bene), nem ser submetidos à coerção decisiva (um tema central dos direitos humanos, idem), que obstruem severamente sua capacidade, tanto subjetivamente quanto em termos da disponibilidade de uma razoável gama de opções. Nestas circunstâncias, aos indivíduos falta suficiente liberdade para serem construídos com base na sua aceitação voluntaria de suas obrigações. Vemos que, ao menos no que diz respeito aos direitos civis, foi reconhecido de diversas maneiras que a condição de agente implica a possibilidade de optar, e que por seu lado a opção implica alternativas que o agente tem boas razões próprias para considerar como válidas. Em outras palavras, as situações impostas por diversas coersões severas que - físicas, econômicas, ou o que for violam a condição de agência. Devido ao progressivo reconhecimento deste fato fundamental - empírico e moral - foi incorporado aos sistemas legais e à jurisprudência dos países pioneiros o requerimento de criar um campo de relações minimamente parelho entre os agentes ${ }^{69}$.

A segunda direção na qual avançou o tema da consideração do ser humano como um agente, foi o surgimento dos direitos sociais ${ }^{70}$. Aqui, de novo, ganhou importância o valor da equidade devida a agentes, se bem que esse valor foi focado em categorias sociais, não sobre indivíduos singulares como geralmente ocorria na lei civil e penal. Por meio de outro grande e complexo processo que não necessito detalhar aqui, os participantes recentemente aceitos na aposta democrática trocaram sua aceitação da democracia política por participação nos benefícios do estado de bem-estar. Esses benefícios não foram somente materiais; através de mecanismos legais de representação coletiva e outros dispositivos, esses atores diminuíram a marcada desigualdade de facto com respeito aos capitalistas e ao estado que, segundo Marx e

\footnotetext{
${ }^{69}$ Além disso, e inclusive antes destes desenvolvimentos relativamente recentes, estes sistemas legais implicavam fortemente - e inclusive requeriam - a presunção de capacidade para a validade de diversas obrigações legalmente fundamentadas. Isto pode ser visto na evolução da lei penal, que se distanciou das sanções coletivas e de métodos inquisidores em direção a critérios de responsabilidade individual e devido processo (ver Lacey, 2001). A mesma presunção pode ser vista também em relação à legislação referidas a indivíduos que não são considerados propriamente pessoas legais (por exemplo, os menores) e sua "representação" por alguém que pode ser legalmente construído assim.

${ }^{70}$ Novamente, de acordo com Marshall (1964, p. 72), os direitos sociais incluem "desde el derecho a un mínimo de bienestar económico y seguridad hasta el derecho de gozar plenamente de los beneficios de la vida social y a vivir la vida de un ser civilizado de acuerdo con el estándar reinante en la sociedad".
} 
outros haviam denunciado enfaticamente, existia por deatrás do universalismo dos sistemas legais existentes. Por meio da legislação e da jurisprudência que tendem a implantar esses benefícios, e com altos e baixos em termos das respectivas relações de poder ${ }^{71}$, estas visões de equidade social também foram incluídas nos respectivos sistemas legais. Elas se agregaram à lei civil e penal, expressando a visão de que, se os agentes podem ser razoavelmente considerados como tais, a sociedade, e especialmente o estado e seu sistema legal, não devem ser indiferentes frente a, ao menos, casos nos quais existem severas privações das capacidades relevantes. Compreendeu-se, então, que se requeriam ações preventivas e compensatórias; essas ações foram desde a obtenção de condições materiais básicas até o estabelecimento de mecanismos variados de representação coletiva para os menos privilegiados. Embora não tenha sido uma completa bênção ${ }^{72}$, estas foram mudanças democráticas, que densificaram o tecido legal que sustenta e leva a cabo a capacidade dos agentes que a democracia pressupõe. É hora de outra proposição:

11. Nos países pioneiros, o tema das opções que fazem realmente possível a agência foi abordado originariamente como uma questão de direitos civis e, mais tarde, também, de direitos sociais. A visão subjacente às construções legais resultantes é, salvo prova em contrário legalmente estipulada, a da equidade que se deve a indivíduos construídos como sujeitos capazes de opções livres e responsáveis ou seja, como agentes.

Parece-me notável (e, de fato, uma das consequências negativas da segmentação disciplinar que prevalece no mundo acadêmico contemporâneo) que, até onde eu saiba, a história que acabo de sintetizar geralmente é ignorada pelas teorias da democracia, do desenvolvimento humano e dos direitos humanos. Isto é lamentável na medida em que todas essas teorias enfrentam a pergunta de se, e até que ponto, deveria haver ao menos um

\footnotetext{
${ }^{71}$ Por exemplo, a ofensiva neoconservadora contemporânea aponta, precisamente, a erosão destas medidas parcialmente igualitárias. Na maior parte da América Latina contemporânea, sacudida por severas crises econômicas e dotada de pobres e incompletos sistemas de bem-estar social, as consequências desta ofensiva têm sido particularmente devastadoras.

${ }^{72}$ Weber (1968) chamou estes processos de "materialização" da lei, já que eles introduziram critérios não universalistas de justiça substantiva na lei formal-racional. Recentemente foi elaborado, desde várias zonas da direita e da esquerda, diversas críticas à "contaminação legal” (TEUBNER, 1986; PREUSS, 1986) alegadamente produzida por esses processos. Observo, entretanto, que estas críticas negam injustificadamente os avanços igualitários alcançados em muitos aspectos por esses desenvolvimentos. Algo que deveria moderar essas críticas é a situação muito mais desfavorável dos pobres e de vários setores discriminados em países, como os da América Latina, onde as políticas de bem-estar e seus consequentes direitos sociais foram adotados e/ou implementados muito parcialmente.
} 
conjunto básico dos direitos e capacidades implicados por seus respectivos campos de incumbência. Vimos como se apresentou esse tema na discussão sobre os direitos, primeiros civis e posteriormente também sociais. Existe muito que aprender disto. Uma lição baseada nos argumentos de agência e equidade usados para justificar a imposição de um campo de relações mais ainda em uma série de relações sociais, assim como nas predições alarmantes que essas tentativas suscitaram. A segunda lição, sobre a qual voltarei, é que a maioria desses direitos não foi outorgada: eles foram conquistados mediante múltiplas lutas de classes subordinadas e setores discriminados. Graças a essas lutas, não poucas vezes, eles(as) conseguiram inscrever suas demandas ${ }^{73}$ com direitos formalmente sancionados e efetivamente implementados.

Começo agora a desenvolver um argumento central para o presente texto: as relações entre agência e suas opções na esfera política - os direitos políticos do regime democrático guardam estreita relação com esta mesma questão referida aos direitos civis e sociais. Obviamente, levantar o problema das opções na esfera política implica ir além da atribuição universalista dos direitos da cidadania política: leva a se perguntar sobre as condições que permitem ou não no exercício efetivo desses direitos - ou, como direi adiante, que habilitam esses direitos ${ }^{74}$. Neste sentido, me parece um grave erro omitir, como fazem muitas teorias politicológicas da democracia, a questão da habilitação da cidadania política quando se refere a indivíduos que estão severamente privados de direitos civis e sociais. É certo que a esses mesmos indivíduos, em um regime democrático, lhes são atribuídos direitos universais que examinamos. Contudo, olhar exclusivamente este lado do assunto significa eliminar da teoria da democracia o problema da agência e, portanto, das opções dos(as) agentes cidadãos(ãs) que o direito civil e a legislação social não têm conseguido ignorar ${ }^{75}$. Esta afirmação pode ser formulada na seguinte proposição.

\footnotetext{
${ }^{73}$ Como observa Méndez, com razão em seu comentário, estas não deveriam ser consideradas simplesmente como aspirações, mas como demandas por direitos acionáveis.

${ }^{74}$ Como assinala Ippolito (O’DONNELL, IAZZETTA, CULLELL, 2003), esta afirmação implica recuperar um tema clássico - o das condições sociais da democracia - como foco central da teoria democrática contemporânea.

${ }^{75}$ Este tema não foi ignorado no berço da democracia. Em seu estudo sobre a democracia ateniense, Hansen (1991) sustenta que Atenas somente se democratizou plenamente quando se decidiu que a participação nas seções da assembléia, no conselho e em outras instituições seria pago um equivalente diário do salário médio. Esta decisão implicou um reconhecimento explícito do problema das capacidades que estou discutindo, já que se dirigiu especificamente a facilitar a participação política dos cidadãos pobres. Por sua vez, Aristóteles (1968) recomendava subsidiar a participação política dos pobres como meio para assegurar a efetividade de sua cidadania.
} 
12. A concepção do ser humano como agente tem consequências diretas e convergentes sobre as esferas civil, social e política, porque é uma concepção moral, que em vários aspectos foi estabelecida legalmente, do ser humano como um indivíduo autônomo, razoável e responsável.

Esta visão não foi proclamada somente em alguns países ricos: foi inscrita também na consciência moral da humanidade pela Declaração dos Direitos do Homem e do Cidadão da França, pelo Prólogo e a Primeira Emenda da Constituição dos Estados Unidos, pela Declaração Universal dos Direitos do Homem das Nações Unidas de 1948, pelo Pacto Internacional sobre Direitos Civis e Políticos, o Pacto Internacional sobre Direitos Econômicos, Sociais e Culturais, a Declaração de Viena sobre Direitos Humanos e outros tratados e convenções internacionais e regionais (incluída a Convenção Americana sobre Direitos Humanos), todos ratificados por uma grande quantidade de países ${ }^{76}$.

\section{A Democracia e o estado}

Nas seções anteriores fomos além do regime. Isto nos exige considerar diversos sentidos em que o estado é relevante para o estudo da democracia. Recordemos que nos países contemporâneos muitos direitos e obrigações estão sancionados e apoiados por um sistema legal, e que este sistema legal é parte do estado. Normalmente, o estado projeta suas regras - a maior parte delas formuladas na gramática da lei - ao longo do território que cobre. Vimos também que para que exista um regime democrático deve haver uma delimitação territorial de seus cidadãos(ãs), e alguns diretos atribuídos a eles. Vimos também que o estado não é só um conjunto de burocracias; é também um sistema legal normalmente apoiado pela supremacia da coerção mantida por suas instituições sobre o território que elas delimitam ${ }^{77}$. Este sistema legal reconhece e constitui como pessoas legais, portadoras de direitos subjetivos, aos indivíduos no território do estado. Disto segue que, na medida em que sanciona e apóia aposta democrática assim como um regime consistente em eleições livres e institucionalizadas e algumas liberdades circundantes, o estado e seu sistema legal são democráticos.

13. A democraticidade é um atributo do estado, não só do regime.

\footnotetext{
${ }^{76}$ Remeto a Held (2002). Claro, entre quem os ratificaram existem governos que ignoram muitos dos direitos envolvidos. Entretanto, em lugar de usar esse fato para diminuir o significado desses tratados e convenções, creio que deveria ser visto como um tributo - embora cínico - pago à força moral dos direitos proclamados nestes instrumentos internacionais.

${ }^{77}$ Para pontos de vistas sobre o sistema legal como parte del estado, ver Bobbio (1989) e, claro, Weber (1968).
} 
Prosseguindo com este tema, menciono que alguns autores consideram direitos tais como os de associação e expressão como diretos negativos, embora esta opinião tenha sido convincentemente criticada $^{78}$. De qualquer forma, os diretos de votar e ser votado são claramente direitos positivos. Também há, ao menos, outro direito, consequência dos anteriores, que também é positivo: o direito ao acesso igual e rápido aos tribunais de justiça. Este direito inclui a expectativa de que algumas instituições do estado se encarreguem de efetuar, quando legalmente lhes corresponde, ações orientadas a garantir os direitos reclamados ${ }^{79}$. Sem esta possibilidade, esses direitos seriam puramente nominais.

Com esta afirmação nos voltamos novamente à questão do estado qua sistema legal que estabelece e apóia os direitos que, apesar dos desacordos entre diversos autores com respeito a quais direitos listar especificamente há ao menos o consenso em considerá-los como condições necessárias da democracia política. Isto me permite completar a caracterização de um sistema legal: não é só um conjunto de regras, mas propriamente um sistema, consistente no entrelaçamento de regras legais e de instituições estatais legalmente reguladas. Por sua vez, uma espécie deste gênero, um sistema legal democrático, está caracterizada por dois elementos adicionais: um é que sanciona e apóia, se é necessário, com sua supremacia no controle dos meios de coerção, dos direitos associados a um regime democrático; o outro, que não há instituição ou funcionário no estado (nem na sociedade) que seja de legibus solutus, quer dizer, acima das leis. Em um estado democrático de direito ${ }^{80}$ todos estão sujeitos à autoridade legal de alguma outra instituição ${ }^{81}$ - este sistema legal "fecha", no sentido de que ninguém está acima ou além de suas regras ${ }^{82}$. Por sua vez, esta característica está estreitamente ligada (como a tradição do constitucionalismo liberal reconheceu precocemente) à proteção dos direitos políticos e de outros direitos; sem essa salvaguarda existiríam poderes em condições de anular unilateralmente esses direitos.

Em uma democracia, ao menos em uma que funcione adequadamente, os governantes devem submeter-se a três tipos de accountability. Uma, a accountability eleitoral vertical,

\footnotetext{
${ }^{78}$ Ver especialmente Holmes e Sunstein (1999), Raz (1986), Sen (1984; 1985), Skinner (1984) e Taylor (1993).

${ }^{79}$ Ver Fábre (1998).

${ }^{80}$ Para mais detalhes ver O'Donnell (2002d). Em minha opinião, este tipo de sistema legal, se é efetivamente implementado, é "um bem normativo intrínseco" ou, em outros termos, "um bem público". As palavras entre aspas pertencem aos comentários de Karl, embora as use em sentido crítico de minha formulação. Creio que isto se deve a que ela deixa de reconhecer que me refiro a um tipo de estado de direito que é por sua vez democrático e efetivo, não a qualquer versão do mesmo.

${ }^{81}$ Isto é o que alguns teóricos alemães designaram como a "indisponibilidade" do sistema legal para os governantes. Ver Preuss (1996a) e Habermas (1986; 1988).

${ }^{82}$ Sobre esta questão, por perspectivas distintas, porém neste sentido convergentes, ver Alchourrón e Bulygin (1971), Fuller (1964), Garzón Valdés (1993), Habermas (1996), Hart (1961) e Kelsen (1967). 
resultante da existência de eleições limpas e institucionalizadas, por meio das quais os cidadãos podem mudar o partido e as pessoas no governo. Outro tipo de accountability vertical, a societal ${ }^{83}$, é exercido por grupos ou indivíduos que conseguem mobilizar o sistema legal a fim de prevenir, reparar e/ou punir ações (ou omissões) presumivelmente ilegais perpetradas por funcionários públicos. Quanto à terceira accountability, horizontal, foi discutida anterior: opera quando alguma instituição estatal devidamente autorizada atua para prevenir, corrigir ou castigar ações ou omissões presuntamente ilegais de outra instituição ou funcionário estatal ${ }^{84}$.

Observe-se, no entanto, que há uma diferença importante entre esses três tipos de accountability. A accountability vertical eleitoral deve existir por definição em um sistema democrático - se não existe, simplesmente não há tal regime. Ao contrário, o grau de efetividade das accountabilities societal e horizontal é variável caso a caso e ao longo do tempo. Estas variações são relevantes para avaliar a qualidade da democracia. Por exemplo, a ausência de uma sociedade vigorosa e auto-afirmativa, ou a impossibilidade - ou falta de vontade - de certas instituições do estado de exercer sua autoridade sobre outras instituições do mesmo (especialmente sobre funcionários eleitos), são indicadores de una democracia de baixa qualidade.

Chegamos a outra conclusão. Acima observei que há duas características específicas da democracia política, que não são compartilhadas por nenhum outro tipo de regime: eleições limpas e institucionalizadas e uma proposta inclusiva. Agora vemos que existem outras duas características igualmente específicas: uma - consequência da própria definição de regime democrático - é a existência de um sistema legal que estabelece e apóia - ao menos - direitos participativos e as liberdades "políticas" associadas a esse regime; a outra é a existência de um sistema legal que prescreve que nenhuma pessoa ou instituição é de legibus solutus ${ }^{85}$. As duas primeiras características estão localizadas no nível do regime, enquanto que as últimas estão no nível do estado. Vemos então, novamente, que um foco exclusivo sobre o regime é

\footnotetext{
${ }^{83}$ Este útil conceito foi proposto por Smulovitz e Peruzzotti (2000). Ver também o volume editado por estes autores (2002); neste livro comentei (O’DONNELL, 2002b) a relação de suporte recíproco nas accountabilities societal e horizontal.

${ }^{84}$ Para discussão da accountability horizontal remeto a O’Donnell (1998; 2001a).

${ }^{85}$ Em todos os outros tipos de regime político alguém (um ditador, um partido de vanguarda, uma junta militar, uma teocracia, etc.) pode abolir ou suspender unilateralmente qualquer direito existente, incluindo os que regulam suas funções. Há, contudo, alguns casos híbridos. Refiro-me aos onde, de maneira formal (Chile) ou informal (Guatemala), as forças armadas conservam áreas de decisão em que exercem poderes fora do controle civil. O mínimo que podemos dizer sobre esta questão é que deteriora seriamente a qualidade democrática dos respectivos regimes.
} 
insuficiente para uma caracterização adequada da democracia: abandonamos o nível da democracia como um regime e ingressamos no do estado.

Estas conclusões podem ser resumidas mediante uma proposição:

14. A democracia tem quatro características distintivas com relação a qualquer outro regime político: 1) eleições limpas e institucionalizadas; 2) uma proposta inclusiva e (limitadamente) universal; 3) um sistema legal que estabelece e apóia - pelo menos - os direitos e liberdades necessários para um regime democrático; e 4) um sistema legal que proíbe que qualquer um que seja de legibus solutus. As primeiras duas características correspondem ao regime; as duas últimas ao estado. Portanto, as teorias sobre a democracia que se limitam ao estudo do regime sub-especificam erroneamente seu tema.

Como ficou definido pelo exemplo dos tribunais, outro aspecto do sistema legal é sua efetividade, quer dizer o grau em que realmente ordena as relações sociais. Isto é função dos entrelaçamentos do sistema legal. Em uma primeira dimensão, que podemos chamar interinstitucional, teremos, por exemplo, a situação de um juiz lidando com um caso criminal, cuja autoridade seria nula se não estivesse apoiada, em vários momentos do processo, pela polícia, por promotores e outros, tanto como por, eventualmente, outros tribunais e as prisões ${ }^{86}$. Em uma segunda dimensão, horizontal, observei que em um sistema legal democrático se supõe que nenhuma instituição estatal ou oficial possa escapar do controle da legalidade de suas ações. Em uma terceira dimensão, territorial, se supõe que o sistema legal se estende homogeneamente através do espaço delimitado pelo estado. Em uma quarta dimensão, estratificacional, se supõe que o sistema legal, os tribunais é claro incluídos, deve tratar todos os casos independente dos atributos de classe, gênero, etnia, etc., de cada um. Em todas estas dimensões, o sistema legal pressupõe o que Linz e Stepan ${ }^{87}$ chamam um "estado efetivo". Em meus termos, este não é somente um problema de legislação adequada, mas também de uma rede de instituições estatais que opera garantindo a efetividade de um sistema legal que em si mesmo é democrático. Veremos que a fragilidade deste tipo de estado é uma das características mais perturbadora da maioria dos países da América Latina. Antes de discutir esta questão adiciono outra proposição:

\footnotetext{
${ }^{86}$ Pelo contrário, os capítulos de Méndez et. al. (2002), mostram conclusivamente que na América Latina estas redes são frequentemente interrompidas, e a lei, consequentemente, é de fato ineficaz.

${ }^{87}$ Linz e Stepan (1996, p.37).
} 
15. A efetividade de um sistema legal depende da articulação de suas regras com uma rede de instituições que atua com propósitos e resultados que são geralmente coerentes, quando existe um regime democrático, com um Estado Democrático de Direito.

Não terminei o estudo das relações entre a democracia e o estado. Lembre-se que, por meio da atribuição de diversos direitos e liberdades, a democracia política constrói aos(às) cidadão(ãs) como agentes. Lembre-se também que esses agentes são portadores de direitos subjetivos, legalmente atribuídos sobre bases (limitadamente) universalistas. Acrescento agora que este sistema legal, começando por suas regras mais elevadas - as de ordem constitucional - estabelece que os cidadãos(ãs), quando tomam suas decisões de voto em eleições limpas, são a fonte de autoridade que exercem sobre eles, o estado e o governo. Os cidadãos não são somente os portadores de direitos e obrigações: eles são também a fonte e a justificação do direito de mandar que o estado e o governo exercem quando tomam decisões ligadas a todos.

A democracia contemporânea dificilmente é pelo povo, mas sem dúvidas é do povo e, devido a isto, deve ser também para o povo. Que a autoridade deriva da cidadania é evidente no caso de quem ocupa posições eletivas de governo. Porém também é verdade no que diz respeito a qualquer funcionário estatal, na medida em que, em um regime democrático, eles recebem sua autoridade dos mais altos poderes - eletivos - do país atuando segundo as respectivas normas constitucionais/legais. Além disso, a jurisdição e as obrigações dos funcionários estatais estão determinadas pelo mesmo sistema legal que, proibindo-os de ser de legibus solutus, sujeita a todos os funcionários, eleitos e não eleitos, à accountability horizontal. Por último, todos os habitantes, inclusive os que não são cidadãos (não adultos ou estrangeiros) são também construídos como agentes pelas regras legais que presidem as relações civis e sociais ${ }^{88}$.

Se conclui disto que um indivíduo não é - nem deve nunca ser visto como um súdito, um suplicante da benevolência do governo e o estado. O indivíduo - um agente portador de um conjunto de direitos civis e eventualmente também sociais, seja ou não cidadão(ã) político(a) - tem direito legal a ser tratado com plena consideração e respeito, e sobre as mesmas bases que qualquer outro ${ }^{89}$. Este tratamento também deve estar baseado na aplicação

\footnotetext{
${ }^{88}$ Como Ippolito observa em seus comentários, o problema dos extrangeiros, particularmente os direitos que lhes são atribuído e o tratamento que recebem do estado e dos(as) cidadãos(ãs), deve ser considerado um aspecto muito importante na avaliação da qualidade de uma democracia. Reconheço que o presente texto não presta suficiente atenção a esta questão.

${ }^{89}$ Nesta direção, Ronald Dworkin (1986, p.165) sustenta que "una exigencia fundamental de moralidad política es que los gobiernos hablen con una sola voz, que actúen de una misma maneta escrupulosa y coherente con
} 
de leis e normas que são claras, reconhecíveis, aplicadas imparcialmente e sancionadas de maneira que condizem com os procedimentos democráticos. Neste sentido, Robert Lane afirma que:

La teoría democrática es reticente respecto a cómo somos tratados por las instituciones políticas, sociales y económicas de las que es teoría se ocupa [Sin embargo, un aspecto crucial de la teoría y de la prática democráticas e que] cómo somos tratados es tan importante como qué obtenemos, [incluyendo] quién trata a quién con dignidad, con un mínimo cuidado y con sensibilidad hacia el sentido de equidad del individuo ${ }^{90}$.

Neste sentido, as instituições do estado podem ser consideradas mais ou menos democráticas - ou como mais ou menos consistentes com as obrigações que lhes impõe a democracia e suas implicações a respeito dos agentes - segundo o grau em que efetivamente reconhecem esses direitos. De fato, pode argumentar-se que este é um dos maiores desafios das democracias. Com relação às eleições limpas e, normalmente, com o exercício dos direitos políticos, os(as) cidadãos(ãs) se localizam num nível de igualdade genérica. Em vez disso, quando se trata de suas relações com burocracias (por certo não só do estado), os indivíduos cidadãos(ãs) ou não - se encontram frequentemente em situações de alta desigualdade de facto. Eles enfrentam burocracias que atuam sobre a base de regras formais e informais que raras vezes são transparentes e facilmente compreensíveis, e que tomam decisões (ou incorrem em omissões) que frequentemente tem importantes consequências sobre as pessoas ${ }^{91}$. É uma triste lei da natureza humana que quando alguns indivíduos se localizam no lado superior de uma relação fortemente desigual, tendem a esquecer que seu direito a exercer autoridade vem dos que estão "abaixo", e que esses são portadores de direitos que exigem plena consideração

todos sus ciudadanos, (e) que extiendan a todos los criterios sustantivos de justicia y equidad que usan con algunos."

${ }^{90}$ Lane (1988, p. 189). Resumindo uma série de estudos nos Estados Unidos, Tyler (2000, p. 990) coincide: "Ser tratados con dignidad y respeto asegura a los ciudadanos que ellos son miembros importantes y valorados de la sociedad, merecedores del reconocimiento de su estatus y de sus derechos. Se trata del reconocimiento de la propia inclusión en la sociedad". Por outro lado, Margalit (1996) faz deste tipo de tratamento a característica distintiva de uma "sociedade decente". Ippoltio (O’DONNELL, IAZZETTA, CULLELL, 2003) comenta, em consonância, que em matéria de políticas sociais "no sólo es importante observar el esfuerzo del estado por proveer capacidades sino también registrar cómo el estado da lo que da" (itálico no original).

${ }^{91}$ A Auditoria (2001) contém uma cuidadosa discussão sobre este problema; por boas razões empíricas, este trabalho decidiu enfocar várias situações de maus-tratos pelas instituições do estado. Adicionam estes autores que "lo opuesto al mal-trato de los ciudadanos nos es el 'buen trato', sino el trato democrático, que tiene lugar, precisamente, cuando las instituciones del estado respetan los derechos y la dignidad de las personas” (p. 199). 
e respeito ${ }^{92}$. Este é um problema em todas as partes. É mais grave, e sistemático, quando uma das partes nessas relações está afetada por pobreza e grave desigualdade generalizadas. Por sua vez, esses males refletem e reproduzem os núcleos autoritários que existem na sociedade. Esta é outra dimensão crucial da qualidade da democracia, na América Latina, com suas profundas e persistentes desigualdades, ela é particularmente importante. Insiro agora duas preposições:

16. Na democracia, as instituições do estado têm o dever (correlativo aos direitos da cidadania política e civil) de tratar a todos com a equidade, consideração e respeito devidos a um agente.

17. Embora a tendência a negar esses direitos esteja estruturalmente inscrita em toda relação vertical de poder (especialmente se está burocratizada), a pobreza e a desigualdade aguda tendem a acentuar poderosamente essa tendência.

\section{Segunda digressão sobre a avaliação da Qualidade da Democracia}

Nas seções anteriores cobri um campo amplo. Agora é hora de associar algumas das conclusões às que cheguei com a avaliação da qualidade da democracia.

\section{1. Em relação ao sistema legal}

VIII.1.1. Se estende-se homogeneamente ao longo do território do estado.

VIII.1.2. Idem ao largo das diversas classes, setores e grupos.

VIII.1.3. Se estabelece regras que proíbem discriminação contra os pobres, as mulheres, os estrangeiros e diversas minorias, e se essas regras se aplicam efetivamente.

\section{2. Em relação ao estado e ao governo}

VIII. 2.1. Se existe um estado que exerce o controle efetivo e legal sobre todo o seu território.

VIII. 2.2. Se existem, e se estão adequadamente autorizadas e providas dos recursos necessários, instituições estatais para o exercício de accountability horizontal,

\footnotetext{
${ }^{92}$ Inclusive em situações onde esta desigualdade é muito alta (como em uma prisão), segue vigente o dever moral de manter o respeito pela dignidade do outro. Em nossos dias isto é habitualmente, também, uma obrigação legal, mesmo que muitas vezes seja esquecido.
} 
inclusive em relação aos casos de ações ou omissões alegadamente ilegais de funcionários eleitos.

\section{3. Em relação aos tribunais e suas instituições auxiliares}

VIII. 3.1 Se existe acesso à justiça razoavelmente livre e expeditivo, nos diversos tipos de tribunais, inclusive para a representação legal de pobres, ausentes, analfabetos, estrangeiros e outros indivíduos ou grupos ao menos potencialmente discriminados ou desfavorecidos.

VIII. 3.2 Se os tribunais reconhecem - e até que ponto e em que tipo de casos - os pactos e tratados internacionais, incluindo aqueles sobre direitos humanos, de gênero, de povos indígenas e da infância.

VIII. 3.3 Se os indivíduos não são enviados à prisão ou submetidos a outras penas em circunstâncias que violam as regras de um devido processo e do tratamento humano devido a todos os agentes, inclusive os afetados por estas situações.

\section{4. Em relação às instituições estatais em geral.}

VIII. 4.1. Se tratam a todos com equidade, consideração e respeito.

VIII. 4.2. Se funcionam de acordo com regras claras, publicamente acessíveis e adequadamente sancionadas.

VIII. 4.3. Se existem mecanismos rápidos e efetivos para a prevenção, interrupção e/ou reparação da violação dos direitos dos cidadãos e habitantes por parte das instituições do estado.

Como as anteriores, esta digressão merece alguns comentários. Um é que os itens precedentes podem ser reformulados de maneira negativa. Isto provavelmente ofereceria um guia empírico melhor nos casos nos quais os déficits nesses itens superarem os ganhos. Um segundo comentário é que é obviamente impossível fazer um diagrama de todos os modos em que as instituições do estado interagem com a população. Contudo, a investigação criativa realizada pela Auditoria mostrou um frutífero caminho para abordar este problema. O mesmo consiste em, primeiro, pressupor que as situações que mais interessam são aquelas em que as instituições estatais se encontram com os pobres, os desfavorecidos, e/ou os discriminados; segundo, eleger entre essas situações as que parecem situar-se nas fronteiras mais problemáticas $^{93}$ entre o estado e a sociedade; e terceiro, por meio de observações etnográficas

\footnotetext{
${ }^{93}$ Para o conceito de "fronteiras problemáticas" entre o estado e a sociedad ver Oszlak e O’Donnell (1984). No texto presente me refiero a situações onde existem vários tipos de maus tratos frequentes (se não sistemático), e 
e "sitios sentinela"94, estudar estas situações em profundidade. Com certeza, isto não fornece um mapa completo dessas interações, porém torna possível localizar situações típicas que merecem atenção, tanto por sua importância intrínseca pelo que dizem sobre o funcionamento cotidiano de uma democracia - e, portanto, de sua qualidade no que diz respeito a esta dimensão estatal da mesma. Esses procedimentos podem ser complementados com vantagem pela observação de situações nas quais se sabe ou se presume que o tratamento é satisfatório.

\section{A Democracia e o Contexto Social}

Muitos teóricos da democracia concordam em que, ademais das liberdades que tenho arrolado, o acesso a uma informação livre, pluralista e não monopolizada ou censurada pelo estado é também condição necessária de um regime democrático. Por exemplo, entre os atributos arrolados por Dahl se encontra a existência de "fontes alternativas de informação" 95 . Observe-se que este não é um direito individual: contar com este tipo de informação é um fato social, independente do desejo de qualquer indivíduo em particular. É um bem público ${ }^{96}$, caracterizado como tal por ser indivisível e não competitivo. Por outro lado, a disponibilidade de informação livre e pluralista é a contracara social dos direitos individuais de expressão e associação; uma e outros se pressupõem e geram mutuamente.

A liberdade de acesso a uma informação livre e plural - bem como sua outra face, os direitos de expressão e associação - se estende, como mostra a enorme atenção dada a elas em teoria e na prática legal, sobre inumeráveis instituições sociais, muito além do regime. Para ser efetiva, esta liberdade pressupõe duas condições. Uma é um contexto social favorável à existência de uma diversidade de valores, crenças, estilos de vida e opiniões. A outra é - mais uma vez - um sistema legal que respalde esta diversidade e, por meio dela, a existência e continua transformação de um contexto social diverso e plural.

Aqui encontramos outro problema de limites: é teoricamente indecidível onde e sobre que base de critérios podemos traçar uma linha divisória clara e firme entre os aspectos da liberdade de informação alternativa que são pertinentes à democracia política e aqueles que não são. Por exemplo, num determinado caso poderia ser permitida uma discussão aberta sobre temas "políticos", mas estes temas poderiam ser definidos estreitamente. Se, por exemplo, a discussão pública sobre direitos de gênero ou vinculados à diversidade sexual estivesse censurada, ou se fosse proibido aos grupos promotores de uma reforma agrária o

onde para os que o sufrem estão em jogo questões (saúde, emprego, documentação, etc.) que são importantes para eles.

${ }^{94}$ Sobre este interessante e inovador método, ver Auditoria (2012, vol. II).

${ }^{95}$ Dahl (1989, p. 221).

${ }^{96}$ Para a discussão deste ponto ver Raz (1986; 1994). 
acesso aos meios de comunicação, teríamos serias dúvidas sobre se corresponde afirmar que esta liberdade tem sido satisfeita. No entanto, num passado não muito distante dos países pioneiros estas restrições não eram consideradas problemáticas. Como vimos em relação aos problemas de limites de outras liberdades, esta também coloca uma questão comparativa complicada: seria apropriado aplicar às novas democracias os critérios que usam atualmente os países ipioneiros, ou deveríamos aceitar critérios mais restritivos, tais como os aplicados por esses últimos décadas atrás? Ou haveria, talvez, outra alternativa?

Com o fim de tratar com estas questões necessitamos avançar um pouco mais na nossa análise. Voltemos às relações implicadas num regime democrático. Vimos que nesta esfera os indivíduos são construídos como agentes; são cidadãos(ãs) políticos que podem votar e serem eleitos(as). Para que o voto seja uma opção real, esses(as) cidadãos(ãs) necessitam evidentemente, um grau significativo de informação livre e plural. Além do mais, se - digamos - Juana tenta ser eleita, necessitará fazer uso de alguns de seus direitos tais como o de expressar suas opiniões e se associar com partidos e com outros cidadãos. Esses são direitos que todas as pessoas podem decidir utilizar ou não. Pedro pode não se importar se esses direitos existem ou não, e inclusive pode considerar inconveniente que outros indivíduos usem esses direitos. No entanto, vimos que num regime democrático contemporâneo - ou seja, inclusivo - esses direitos são designados universalmente, com independência das preferências de Pedro.

Este raciocínio se vincula com um argumento que Joseph Raz desenvolveu frutiferamente ${ }^{97}$. A efetividade de direitos como os que tenho enumerado é um bem público porque, diz,

El interese de los individuos de vivir en una sociedad abierta no está limitado a los que desean beneficiarse de ella como productores o consumidores de información u opinión. Se extiende a todo los que viven en esa sociedad, por el beneficio que todos obtienen de que algunos intercambien libremente informaciones y opiniones ${ }^{98}$.

Raz continua argumentando que esta é a principal razão pela qual esses direitos são geralmente afirmados como direitos constitucionais. Estejamos ou não de acordo com este ponto, fica claro que os direitos de Juana seriam inefetivos se não existisse um contexto social favorável ao seu objetivo (um contexto que, por exemplo, não discrimine contra as mulheres que atuam em política). Sem o bem público de um contexto social diverso, a efetividade dos

\footnotetext{
${ }^{97}$ Ver Raz (1986; 1984).

${ }^{98} \operatorname{Raz}$ (1986, p. 253). Sen (1993, p. 31), concorda: "La libertad individual es un producto quinta esencialmente social".
} 
direitos políticos estaria seriamente ameaçado. Quando um contexto social diverso existe, este bem público beneficia a todos, inclusive aos que não o consideram valioso.

Existe outro ponto que quero destacar, porque se conecta com o desenvolvimento humano e os direitos humanos. Na conceitualização de Sen, a concepção dos seres humanos como (o que aqui chamo) agentes implica que eles tenham um conjunto de capacidades (capability set), ou seja, uma "serie de vectores que define los funcionamientos [possíveis]" de cada um(a). Estas capacidades $\mathrm{e}^{99}$ funcionamentos "son un modo de caracterizar la libertada positiva y pueden ser vistas como derechos - derechos positivos a hacer esto o aquello" ${ }^{100}$. Um conjunto adequado de capacidades permite ao indivíduo escolher entre os vários funcionamentos que sua razão prática indíca-lhe como valiosos; de acordo com Sen, este é o direito positivo de decidir, com razoável autonomia, conhecimento e responsabilidade, o curso da própria vida - em meus termos, para ser propriamente um agente.

Existem muitas vidas entre as quais é possível escolher, mas cada um somente pode optar por uma ou poucas delas. Nossa condição de agentes e a liberdade para escolher nossos próprios caminhos estão na base da diversidade social ${ }^{101}$. Que muitos outros tenham vivido e vivam outras vidas enriquece a minha ${ }^{102}$. Além do mais, que esses outros sejam agentes compromete meu dever moral de (exceto casos especiais que um sistema legal democrático legisla cuidadosamente) aceitar e inclusive celebrar, não somente tolerar ${ }^{103}$, que eles tenham elegido vidas diferentes da que eu vivo. O resultado agregado é um contexto social que valoriza positivamente a diversidade que inscreve os respectivos direitos em seu sistema legal. Além do mais, um contexto social semelhante, povoado de agentes diversos legalmente respaldados, oferece um bem público que os governantes autoritários mais se esforçam em suprimir: a possibilidade de emergência de uma esfera pública de discussão e deliberação livres sobre questões de interesse geral $^{104}$.

\footnotetext{
${ }^{99}$ Sen (1985b, p. 20-21).

${ }^{100} \operatorname{Sen}(1985 \mathrm{a}, \mathrm{p} .16)$.

${ }^{101}$ Este argumento é sustentado, especialmente, por Berlín (1969) e Raz (1994). Os argumentos de Berlín grearam una série de interessantes - e complicadas - discusões sobre o pluralismo valorativo - ver entre outros Gray (2000) e Newey (1998) nas quais não posso entrar aqui.

${ }^{102}$ Como diz Raz (1986, p. 381), "Una teoría moral que reconoce el valor de la autonomía [quero dizer, da capacidad de agência, $\mathrm{O}^{\prime} \mathrm{D}$ ] sostiene inevitablemente una perspectiva pluralista. Admite el valor de un gran cuantidad de diferentes metas [de vida] entre las cuales los individuos son libres para elegir", porque (RAZ, 1994, p. 119) "los distintos caminos que podemos seguir en nuestras vidas son al mismo tiempo valorables e incompatibles".

${ }^{103}$ Sobre os limites da tolerância como uma atitude moral adequada frente aos seus agentes e seus direitos, ver a excelente discussão de Garzón Valdés (2011).

${ }^{104}$ É claro, o grau no qual esta possibilidade é realizada varia significativamente caso a caso; discuto alguns destes fatores relevantes para isto mais abaixo.
} 
Vejamos agora que o que tenho denominado até agora de liberdades "políticas" (de expressão, associação, movimento e outros) são na realidade segmentos de mais vastos $e$ antigos direitos civis. Esses direitos se exercem em múltiplos âmbitos da sociedade, não somente no regime. Esses, em parte civis e em parte políticos, são os mesmos direitos. Eles pertencem a agentes que os necessitam para escolher livremente os cursos de ação que consideram valiosos ${ }^{105}$.

Podemos agora tirar algumas conclusões. Uma é de que, se minha vida é enriquecida por um contexto social plural diverso, então é meu interesse que todos os indivíduos tenham os direitos e as capacidades necessárias para escolher livremente seus caminhos. Outra conclusão é que também é meu interesse que esses direitos se inscrevam num sistema legal, para serem especificados e protegê-los de posições hostis aos mesmos. Uma terceira conclusão é de que o agregado social desses direitos individuais, quando são estabelecidos ampla e efetivamente, se converte num bem público de liberdades que podem geralmente ser desfrutadas, e que rodeiam e tornam possível um regime democrático. Uma quarta conclusão é que, se esses diretos são truncados (ou seja, se estão débil ou enviesadamente implantados), a diversidade do contexto social se empobrece e com isso se enfraquece a possibilidade do surgimento da esfera pública rica própria de uma democracia com elevada qualidade.

Essas conclusões em relação à democracia conduzem diretamente ao tema dos direitos humanos e do desenvolvimento humano. Destacar e tratar de remediar carências severas nestas três dimensões não é somente um ato de benevolência; é consequência do dever moral de cada agente de tratar a todos os demais agentes como tais ${ }^{106}$. Além do mais, em múltiplas esferas da vida social tratar a todo alter como um agente é uma obrigação legal; já observei esta obrigação no que se refere às relações entre cidadãos políticos, em muitas relações sociais e nos encontros entre as instituições e os indivíduos.

Voltando para Juana, quem escolheu, entre seus funcionamentos possíveis (nos termos referidos por Sen), atuar na política. Muito provavelmente, ela não teria feito esta opção se previsse que isso poderia lhe acarretar o risco de violência física e/ou privações materiais. Neste caso, Juana não teria considerado que atuar na política estava dentro do conjunto de suas capacidades. Ao decidir assim fazer, além do mais, Juana pressupõe a existência de lugares institucionalizados (o partido político com o qual se identifica, o movimento social no qual milita ou talvez simplesmente o parque público no qual se discursa

\footnotetext{
${ }^{105}$ Em seus comentários Lechner inclui uma interessante lista de "capacidades sociais que influenciam a ação dos cidadãos”. De um ángulo diferente, mas neste aspecto convergente, Rawls (1993, p. 180) afirma que "estos son bienes [...] que los ciudadanos necesitan como personas libres e iguales, y los reclamos de esos bienes son reclamos justos".

106 "O racionalismo ético" de Alan Gewirth (1978) e as discussões que gerou (REGIS, 1984) são relevantes para este ponto, mas não posso ocupar-me disto no presente texto.
} 
aos frequentadores) onde ela pode exercer seus direitos de expressão, associação e movimento. Aqueles como eu que viveram sob-regimes autoritários sabem que isto é exatamente o que não se pode considerar como dado nessas situações. Claramente, a agencia de Juana estaria comprometida se não pudesse adotar esse funcionamento porque sofre sérias privações materiais: “el agente autónomo es alguien que no está constamente luchando por mantener las condiciones mínimas de una vida digna" $"$.

Juana, que não sofre estas privações, entra na política. Ali ela encontra outros cidadãos em relação aos quais a aposta inclusiva da democracia conferiu os mesmos direitos e deveres que ela tem. Juana pode, então, tratar de persuadir, negociar ou o que fosse, mas está proibida assim como os outros de usar a violência ou ameaçar de fazê-lo, bem como - se tem sucesso em ser eleita - de aceitar subornos e, em geral, violar os direitos e obrigações legalmente definidos de sua função.

Em todos esses sentidos, Juana é um ser discursivo: processa e transmite informação e opiniões. Fazendo isto, se sustenta sobre e utiliza, várias fontes de informação; assim se beneficia de e reforça um contexto social diverso e plural.

No entanto, Juana pode preferir não empreender atividades diretamente políticas. Pode optar por participar num sindicato, numa associação de vizinhos, num clube ou outros. Em qualquer dessas opções, Juana continua a ter o direito a um tratamento respeitoso e equitativo - um agente é um agente em qualquer lugar. No entanto, alguns espaços sociais, tais como uma empresa, a Universidade de Notre Dame ou o PNUD, podem criar o tipo de restrição que mencionei em relação ao funcionamento de algumas instituições do estado. Refiro-me a considerações de organização ou eficácia que inibem a democratização interna dessas instituições. No entanto, ainda que nesses casos Juana tem o direito de exigir ${ }^{108} \mathrm{o}$ reconhecimento de seus direitos civis, bem como os que, como parte da evolução de direitos aos que me referia acima, tenham sido sancionados como direitos trabalhistas.

De qualquer forma, Juana tem sorte. Não somente tem as capacidades necessárias senão que vive num contexto social diverso. Porém, nem todo regime democrático está acompanhado por um grau apropriado de democraticidade do estado, ou por um contexto social que porporcione a todos o direito de, ao menos, um mínimo de direitos plenos e de capacidades de desenvolvimento humano ou por um contexto social de ampla diversidade. Essas exceções me conduzem a dar uma olhada nas democracias latino-americanas contemporâneas. Antes de nos ocupar com este assunto, no entanto, devo discutir um pouco mais o tópico da presente seção que retomarei depois de colocar um par de proposições:

\footnotetext{
${ }^{107} \operatorname{Raz}(1986$, p. 155).

${ }^{108}$ Como a legislação e a jurisprudência, especialmente nos países iniciadores, foram, progressiva ainda que insuficientemente, reconhecendo.
} 
18. A efetividade dos direitos de cidadania política requer um contexto social que inclui fontes de informação variadas, não monopolizadas ou censuradas pelo estado. Esta possibilidade, que é um componente de um contexto socialmente diverso e plural, é um bem público respaldado por um sistema legal democrático e pelo desempenho adequado das instituições estatais.

19. De maneira mais ampla, a existência de um contexto social semelhante, juntamente com a existência de diversas liberdades "politicas", na medida em que implicam que múltiplos agentes podem escolher livremente seus funcionamentos, é um aspecto social que reconhece e alimenta a mesma agencia que a democracia pressupõe.

Devo ainda esclarecer um pouco mais a relação entre a democracia e um contexto social diverso ou plural ${ }^{109}$. Um primeiro passo útil é raciocinar ao contrário. Parece claro que não existiria um regime democrático num país onde a informação fosse monopolizada ou amplamente censurada. Num contexto social semelhante não existiria informação suficiente para que o voto tivesse sentido, mesmo que os direitos de expressão e associação estivessem formalmente estabelecidos. Positivamente, este raciocínio mostra que os direitos de expressão, associação, movimento e outros semelhantes têm duas caras ${ }^{110}$. Já tenho discutido uma delas: a individual. A outra é que a existência desses direitos "individuais" é também, e não menos fundamentalmente um fato social; esses direitos se alimentam de - e ao mesmo tempo geram um contexto social cuja diversidade expressa - junto com diversos valores e práticas culturais, religiosos, artísticos e outros - a própria efetividade desses mesmos direitos. Falei no início deste texto que os direitos "políticos" são condições necessárias para um regime democrático. Mais adiante argumentei que esses direitos são na realidade parte de mais antigos e mais amplos direitos civis. Agora vemos que esses mesmos direitos - tanto no seu aspecto político como na sua faceta civil - tem uma dimensão social: não podem existir fora das instituições, valores e práticas sociais. Esses são os milieux de existência desses direitos. Ao que, em sua expressão social, tenho denominado de liberdades. Por outro lado, esses milieux são gerados e reproduzidos pela realização desses mesmos direitos. Este lado social (ou coletivo) dos

\footnotetext{
${ }^{109}$ Neste parágrafo, e no seguinte, levo em conta algumas críticas que Vargas Cullell formulou em uma versão prévia deste texto.

${ }^{110}$ Mencionei o argumento de Raz a este respeito. A partir de perspectivas diversas, podem encontrar-se outros valiosos argumentos sobre o "lado social" dos direitos em Garzón Valdés (1993), Habermas (1996), Holmes e Systein (1999) e Waldron (1999).
} 
direitos é o complemento dos direitos políticos: ambas caras da moeda são condições necessárias para a existência de um regime democrático.

Observe-se que o raciocínio precedente é correto, também queremos avaliar a democraticidade do contexto social, ou ao menos seu grau de afinidade com a democracia. Neste sentido, podemos hipotetizar razoavelmente que existem diferentes influências recíprocas entre a qualidade de uma democracia e as características de seu contexto social. Em particular (tal como seria avaliado por meio dos itens sugeridos na primeira parte), se os cidadãos utilizam amplamente seus direitos civis e políticos e apoiam decididamente a democracia, então o contexto social tenderá à diversidade e a consistência com ela. Reciprocamente, um contexto social semelhante tende a promover atitudes desse tipo, por parte dos(as) cidadãos(ãs). Há uma óbvia circularidade, que sublinha a mutua e necessária imbricação das dimensões individual e social dos direitos políticos e de outros direitos.

Resumo o que foi dito em uma proposição:

20. Os direitos até agora examinados (politicos e civis), na medida em que são designados a sujeitos construídos como agentes, tem uma dimensão intrínseca a individual. Porém, na medida em que se projetam coletivamente como liberdades que caracterizam - e sustentam - um contexto diverso e plural, esses mesmos direitos têm uma dimensão não menos intrinsecamente social.

Por último, um contexto social diverso é importante não somente para a realização dos direitos políticos associados a um regime democrático. Um contexto semelhante é também o espaço social onde os(as) cidadãos(ãs) (e, em geral, os(as) habitantes) exercem direitos e poderes que não transferiram ao estado nem por empréstimo temporário aos funcionários eleitos $^{111}$. Este é um exercício público, na medida em que estimula - sob os auspícios de um contexto social favorável e de direitos que este reconhece - o diálogo aberto sobre questões que são, ou que os interlocutores supõem ser, de interesse geral.

\section{Terceira digressão sobre a avaliação da Qualidade da Democracia}

Tenho listado nas digressões anteriores vários dos itens relevantes para a presente seção. Os que neste momento precisam ser agregados são:

\section{X.1. Em relação com o contexto social.}

\footnotetext{
${ }^{111}$ Vargas Cullell me fez esta observação em conversas pessoais.
} 
X.1.1. Se, em geral, existe um contexto social diverso e plural expresso, entre outros meios, em pesquisas de opinião pública, na legislação, em decisões judiciais e nos meios de comunicação, com especial atenção a indicadores de discriminação e intolerância.

X.1.2. Se os meios de comunicação oferecem informação, opiniões e análises sobre assuntos diversos de interesse público, e se ao menos, parte dessa informação, opiniões e análises pode ser considerada razoavelmente autônoma de interesses ou pressões do estado, do governo e/ou de diversos interesses privados.

X.1.3. Se nas associações não diretamente políticas existem direitos de participação de seus membros ou se ao menos são respeitados os direitos civis (e nos seus casos trabalhista) dos mesmos.

X.1.4. Se existem liberdades e garantias adequadas para o exercício de diversas ações de accountability vertical social.

\section{Sobre as Democracias Latinoamericanas Contemporâneas}

Na América Latina contemporânea diversos países satisfazem atualmente a definição de democracia política aqui proposta. Eles compartilham duas características: por um lado, existem eleições limpas, institucionalizadas e inclusivas; por outro lado, regem alguns direitos, especialmente de opinião, expressão, associação, movimento e acesso aos meios de comunicação razoavelmente livres e pluralistas. Alguns países latino-americanos possuem atualmente este tipo de regime, embora existam variações quanto ao grau em que se verificam os atributos mencionados. Essas variações são as que tratam de captar empiricamente a primeira digressão, como indicações da relativa democraticidade, ou qualidade, do respectivo regime. Além do mais, na América Latina há também variações significativas em relação com o grau com que o estado e seu sistema legal cobrem o território e seus moradores, bem como na medida em que a legislação, as instituições estatais e a jurisprudência apontam efetivamente a eliminar diversas formas de discriminação e exclusão. Estas dimensões tem apontado as seguintes digressões embora esteja claro, em geral a disponibilidade de indicadores empíricos válidos e confiáveis é bastante menor em relação ao regime ${ }^{112}$.

\footnotetext{
${ }^{112}$ Nestas matérias espero que resultem consideráveis avanços do projeto atualmente em desenvolvimento, "Desafío de la Democracia en América Latina", também patrocinado pela Divisão para América Latina e Caribe do PNUD e dirigido na Argentina por Dante Caputo. O texto identificado como O’Donnell (2002a) escrevi para este projeto.
} 
Em relação a esses fatores e com as limitações apontadas, uma classificação dos países latino-americanos contemporâneos poderia ser a seguinte ${ }^{113}$ :

1. Países onde as características de um estado democrático são basicamente satisfeitas.

\section{- Costa Rica}

- Uruguai

- Chile (embora os "enclaves autoritários" $" 114$ herdados do regime de Pinochet colocam importantes dúvidas sobre a adequação de situar a Chile neste grupo)

2. Países que podem ser classificados como democracias políticas, ou regimes democráticos: satisfazem as características pertinentes em nível nacional, porém mantém descontinuidades significativas em termos de alcance da legalidade do estado em diversas regiões, incluindo características não democráticas de alguns regimes sub-nacionais.

- Argentina

- Bolívia

- Brasil

- Colômbia (mereceria uma classificação especial, em virtude da extraordinária falta de alcance do estado e sistema legal sobre seu território, bem como a extrema violência que tem sido aplicada contra candidatos de partidos de esquerda) ${ }^{115}$

- México (recentemente)

- Panamá

- Peru

- República Dominicana

\footnotetext{
${ }^{113}$ Excluo desta classificação El Salvador, Honduras, Nicarágua e quase todos os países do Caribe pela simples, ainda que não muita satisfatória, razão que não conheço o suficiente sobre eles. Ademais, como revelam vários dos comentários a este texto, esta tipologia necessita - ao menos - refinamentos e especificações posteriores; de todas as formas, a apresento na esperança de que ajude futuros esforços para aperfeiçoá-la ou, se for o caso, desfazer-se dela.

${ }^{114}$ Sobre este tópico ver Garreton (1987) e Valenzuela (1982).

${ }^{115}$ A referência a candidatos de partidos de esquerda devo a comentários de Alcántara Sáez na oficina onde apresentei a versão original do presente texto.
} 
- Panamá

3. Países que podem ser classificados como "democracias políticas condicionais", devido a que, além de compartilhar as características do grupo precedente no que se refere ao limitado alcance da legalidade estatal, não é certo, embora em cada caso por razões diferentes, que tenha se institucionalizado um sistema de eleições limpas.

- Equador

- Guatemala (com a advertência adicional de que as forças armadas constituem, embora não formalmente como no Chile, um importante enclave autoritário)

- Venezuela

4. Países que podem ser classificados como "regimes não democráticos de base eleitoral", nos quais a despeito de ter tido eleições, estas ainda não são limpas (essencialmente na sua dimensão decisiva) e não estão institucionalizadas.

- Paraguai

- Haiti

Observe-se agora a tabela incluída como Anexo 1 do presente texto. Observamos que há uma sensível queda na aceitação da "democracia como tipo de governo" no período relativamente breve de 1995-2001, uma queda média de não menos do que 11\% do total dos entrevistados. Coerentemente com a classificação que acabo de propor, vemos também o alto nível de apoio a esse regime nos dois países que não suscitam dúvidas no que diz respeito a sua democraticidade, Costa Rica, e Uruguai, ${ }^{116}$ assim como um nível de apoio significativamente mais baixo no Chile. Observem-se, também, os baixos níveis de apoios em países grandes, Brasil (30\%) e Colômbia (36\%), bem como em El Salvador (25\%) e Panamá (34\%), junto com a forte queda de apoio na Argentina (-18\%), Colômbia (-14\%), El Salvador (-31\%) e Panamá (-1\%). Os dados de outros países são difíceis de interpretar devido a sua recente democratização (México) ou redemocratização (Peru), ou as incertezas provocadas

\footnotetext{
${ }^{116}$ Nestes dois países os níveis de aceitação da democracia são semelhantes aos dos países do Noroeste. Na década de 1990, o apoio médio à democracia nestes países, medido por meio de uma pergunta muito semelhante à da Tabela do Anexo 1, era de 83\% (DALTON, 1999). Excluí Irlanda do Norte da lista - 65\% devido às particulares circunstâncias da mesma, e especialmente porque seu regime dista de ser democrático.
} 
pelas peculiaridades do regime atual (Venezuela). Porém, o baixo nível de apoio à democracia, especialmente sua acentuada queda na maioria dos países entre 1995 e 2001, é muito significativo. Esta sensação se vê reforçada pelas respostas recebidas a outra pergunta incluída na mesma pesquisa: "Quão satisfeito você está com o funcionamento da democracia em seu país?" Somente Costa Rica e Uruguai alcançam um não muito brilhante resultado de cerca de $40 \%$ de respostas positivas. Nos outros países pesquisados as respostas insatisfatórias superam os $60 \%$, com Brasil e Argentina com um contundente 80\% e Colômbia com $90 \%$.

Vista desde esta perspectiva - a opinião popular -, a democracia não anda bem na América Latina. Uma razão importante é que frequentemente a imagem que oferecem os governos democraticamente eleitos é que não podem ou não querem enfrentar problemas fundamentais do desenvolvimento, da equidade social e inclusive da violência. Atrás dessas imagens se encontra o triste fato de que nas últimas duas décadas em boa parte da América Latina o estado se debilitou terrivelmente e, em algumas regiões desses países, virtualmente se evaporou. A crise econômica, a inflação alta, a fúria antiestatal da maioria dos programas de ajuste econômico, a corrupção e o clientelismo contribuíram para gerar um estado anêmico ${ }^{117}$.

Esta anemia aparece também no sistema legal. De fato, muitos dos nossos países têm um regime democrático que coexiste com um sistema legal que rege de maneira intermitente e socialmente enviesada. A legalidade do estado não alcança vastas regiões de nossos países (assim como partes cada vez maiores das cidades), onde outros tipos de lei - basicamente variações da lei da máfia - são as que efetivamente regem ${ }^{118}$. Além do mais, mesmo nas regiões abrangidas pelo sistema legal, este é aplicado frequentemente com critérios discriminatórios em relação a diversas minorias, e inclusive maiorias, tais como os pobres e as mulheres. Este sistema legal truncado gera o que chamo de uma cidadania de baixa intensidade. Com isto quero dizer que todos têm, pelo menos em princípio, os direitos políticos que correspondem a um regime democrático, mas a muitos lhes são negados os direitos sociais básicos, como sugere a extensão da pobreza e a desigualdade que não preciso documentar aqui. A estas pessoas também lhes são negados direito civis básicos; não têm proteção da violência policial nem das diferentes formas de violência privada; se lhes nega $o$ ágil e respeitoso acesso às instituições do estado e aos tribunais; seus domicílios podem ser invadidos arbitrariamente, e, em geral, são forçados a levar uma vida que não é só de pobreza, mas também de sistemática humilhação e medo à violência, frequentemente perpetrada pelas

\footnotetext{
${ }^{117}$ Em seus comentários Iazzetta e Conaghan elaboram utilmente sobre o tema, ainda que a última crítica da visão em sua opinião excessivamente pessimista que apresento aqui.

${ }^{118}$ Ver O’Donnell (1993) onde traço um mapa metafórico de áreas azuis, verdes e marrons segundo o grau em que funciona a legalidade estatal.
} 
mesmas "forças de segurança" que se supõe devem protegê-los ${ }^{119}$. Essas pessoas, as quais chamarei de setor popular, não são materialmente pobres, são também legalmente pobres.

No entanto, pelo menos em eleições nacionais, essas mesmas pessoas - como ocorre por definição - nos países que tenho classificado como democracias políticas, votam sem sofrer coerção física, seus votos são computados limpamente e em princípio podem usar os direitos para se expressar, associar-se, deslocar-se e assim por diante. Esta é uma situação de efetividade dos direitos políticos que rodeiam e que tornam possível um regime democrático, e ao mesmo tempo, de negação, não só de muitos direitos sociais - a maioria, em alguns países - mas também e não menos grave, de diversos direitos civis.

Um aspecto da precária cobertura territorial da legalidade do estado é de que em alguns dos nossos países existem regiões onde as eleições locais não são limpas. Trata-se de regimes autoritários subnacionais de base eleitoral ${ }^{120}$. No entanto, estas regiões "marrons" enviam seus representantes às instituições políticas nacionais do regime, permeando-as com atores, interesses e estratégias não democráticas. Estes problemas são compartilhados por muitas novas e não tão novas democracias políticas no mundo contemporâneo. No entanto, está é uma experiência historicamente única, em termos da trajetória dos países iniciantes.

$\mathrm{O}$ que tem a dizer sobre isto a teoria democrática? Lamentavelmente, não muito. Em boa medida isto se deve a que muitas teorias da democracia têm sido formuladas dentro de - e levando em conta - a experiência do Noroeste. Estas teorias deixam implícito que, como já vimos, nessa região os direitos civis já eram razoavelmente efetivos, e estavam bastante estendidos para a sociedade. Antes da adoção da aposta democrática inclusiva e a universalização dos direitos políticos. Além do mais, estas teorias pressupõem que a legalidade do estado se estende homogeneamente por meio de seu território e que, em consequência, não somente o regime nacional, mas também os regimes subnacionais, são

\footnotetext{
${ }^{119}$ Os relatórios de diversas organizações de direitos humanos documentam reiterada e abundantemente a permanente ameaça de violência a que estas pessoas estão submetidas. Sobre Brasil ver Dellasoppa et. al. (1999), que documentam que a incidência de mortes violentas nas áreas mais pobres da região metropolitana de São Paulo é dezesseis vezes mais alta que a das mais ricas; para dados sobre a Argentina ver, entre otros, CELS (1998). Mais geral, um estudo de diversos conjuntos de dados sobre crime violento encontra em todos eles uma persistente e frequentemente forte correlação positiva entre o mesmo e a pobreza e desigualdade de renda. (HSIEH e PUGH, 1993). Os pobres é claro, são as principais vítimas desta violência.

${ }^{120}$ Este é outro aspecto que a Ciência Política contemporânea dominante, devido a sua concentração sobre o regime nacional, tendeu, com poucas exceções, a ignorar. Esta omissião é empírica e teoricamente custosa; inclusive perspectivas exclusivamente centradas no regime nacional deveriam considerar os impactos dos regimes autoritários subnacionais no funcionamento daquela.
} 
democráticos ${ }^{121}$. Lamentavelmente, estas pressuposições não se ajustam a trajetória histórica e a situação presente da maior parte da América Latina. Dar conta em teoria e na prática dessas especificidades, é um dos grandes desafios das ciências sociais latino-americanas, que por certo não estarão satisfeitas copiando "chave na mãs" as teorias e modelos elaborados no Noroeste.

Entre os países pioneiros, observo uma variação básica. O Reino Unido, França, Escandinávia e outros seguiram de modo geral a sequencia estudada por Marshall ${ }^{122}$. Ou seja: primeiro, extensão de direitos civis, depois de direitos políticos e finalmente direitos sociais. Por outro lado, a sequência prussiano/alemã significou alcançar primeiro direitos civis, depois direitos sociais e somente mais tarde os direitos políticos. No entanto, em ambas sequências os direitos civis foram bastante efetiva e amplamente implantados antes que se alcançassem outros direitos. Isto é mais verdadeiro em relação aos homens do que às mulheres e algumas minorias, mas necessito discutir outras questões antes de voltar a este ponto ${ }^{123}$.

Com algumas exceções que não afetam o sentido geral de minha argumentação, estas sequências norocidentais se aplicam de maneira geral a Costa Rica, Chile e Uruguai. Costa Rica e Chile seguiram, com exceções que não posso analisar aqui, o padrão marshaliano de direitos civis-politicos-sociais, embora nas últimas três décadas o Chile tenha experimentado uma profunda regressão em termos dos últimos direitos. O Uruguai, com seu precoce estado de bem-estar, alcança quase que simultaneamente direitos civis, sociais e políticos. De um modo ou outro, o padrão desses países é semelhante aos do Noroeste no sentido que, especialmente nos setores urbanos, existiu um grau razoavelmente alto de implantação de direitos civis antes de, ou mais ou menos simultaneamente com, a obtenção dos direitos políticos. Por certo, apesar das interrupções autoritárias sofridas pelo Chile e Uruguai, estes três países são as democracias políticas mais prolongadas e aparentemente mais firmes na América Latina. Além do mais, embora com a exceção já feita em relação ao legado pinochetista no Chile, estes três casos são os que mais se aproximam aos padrões típicos de funcionamento dos regimes norocidentais.

Não foi esse o caminho seguido pelo resto dos países latino-americanos. Embora o padrão geral tenha sido o seguinte: primeiro, a outorga de alguns direitos sociais, mais limitados que no Noroeste e que nas últimas décadas têm sofrido, em muitos países, retrocessos severos. Depois, a aquisição de direitos políticos, por meio de processos passados

\footnotetext{
${ }^{121}$ Para um capítulo na sociologia do conhecimiento, estas presunções ignoram nada menos que a experiência dos Estados Unidos, onde durante longo tempo os regimes subnacionais do Sul eram claramente autoritários, ainda que tivessem eleições.

${ }^{122}$ Ver Marshall (1964).

${ }^{123}$ Como mostra o que já foi comentado, nenhuma destas sequências se aplica aos Estados Unidos e aos peculiares problemas criados pela escravidão nesse país; mas não posso discutir este tema no presente texto.
} 
e recentes de democratização política. E, por último, ainda hoje, direitos civis implantados de maneira enviesada e intermitente. Este é o padrão populista seguido por Argentina, Bolívia, Brasil México e Peru.

Os casos de Colômbia e Venezuela são diferentes devido a suas precoces democratizações políticas não populistas, que significaram a obtenção de direitos políticos em primeiro lugar. No entanto, esses países compartilham com os populistas o fato de que os direitos civis não tenham se estendido significativamente nem antes nem depois da obtenção de direitos políticos. Por sua parte, Equador e Guatemala, que tem alternado entre regimes autoritários e democrático-oligarquicos de diversos tipos, exibem até hoje um conjunto de direitos políticos bastante limitado (especialmente em relação com suas populações indígenas) e escassos avanços em termos de direito civis e sociais.

Resumindo a discussão precedente:

Em contraste com os países pioneiros, na maior parte da América Latina (e, em termos de população, para a grande maioria da população desta região), os direitos politicos foram obtidos, ou têm sido recuperados recentemente, antes de completar-se uma generalização dos direitos civis. Por sua vez, dependendo da trajetória seguida por cada país, alguns direitos sociais foram outorgados antes ou depois dos direitos politicos, mas em todos os casos esses direitos foram limitados e ultimamente têm sofrido, em muitos países, retrocessos significativos.

Nesses países a penetração e efetividade da legalidade estatal têm sido intermitente e socialmente enviesadas. Além do mais, em não poucos países, inclusive sob governos democraticamente eleitos, as regiões cobertas pela legalidade estatal não tem diminuído e em alguns casos tem aumentado.

Em consequência, uma imagem da América Latina contemporânea nos diz que: 1) Na maioria dos nossos países, como correlato da inauguração de regimes democráticos, alcançamos a universalização dos direitos políticos; 2) No entanto, somente conquistamos uma limitada e parcial implantação de direitos civis, os que, além do mais, estão pouco estendidos para amplos segmentos das respectivas populações; 3) Em vários casos tem havido um retrocesso nos limitados direitos sociais que se haviam conseguido; e 4) Com a exceção da Costa Rica e Uruguai, o apoio ao regime democrático é baixo e tem diminuído durante os últimos anos.

Insisto que em termos de trajetórias históricas da democracia este é um padrão muito singular. Embora uma democracia duradoura, a India deveria ter alertado sobre esta singularidade, as teorias atuais da democracia estão pobremente preparadas para lidar com 
este tipo de situação. Em particular, uma perspectiva centrada unicamente no regime talvez (e somente talvez) pode ser admitida quando se pode presumir que a efetividade da cidadania civil e social não é problemática. Mas quando, como argumentei, estas dimensões da cidadania estão distribuídas de modo intermitente e enviesado, é crucial levá-las em conta com cuidadosa consideração empírica e teórica, inclusive para entender o funcionamento dos respectivos regimes.

Claro que esses severos déficits de direitos civis e sociais não afetam a todos. Os membros das classes altas e médias (intelectuais incluídos) estamos em melhores condições sob as democracias políticas do que sob o autoritarismo, embora nem todos estejam desde o ponto de vista econômico. Esta situação não é nova na América Latina, mas é perturbador que sob a democracia política em não poucos dos nossos países as condições sociais tenham piorado. A despeito disto, sugiro que uma possível solução para esta situação consiste em usar a inversão desta sequência histórica como um trampolim para a expansão dos direitos que atualmente faltam. Ou seja: em lugar de argumentar que os direitos políticos da democracia são "puramente formais", usá-los para conquistar outros direitos. Isto é o que as feministas e alguns movimentos de minorias têm feito no Noroeste: usar os direitos políticos como plataforma para lutar por direitos civis e sociais. Esta estratégia tem sido qualquer coisa menos o processo bastante sequencial de conquista de direitos (basicamente masculinos) que descrevi acima. Tem consistido em um prolongado movimento de idas e vindas, desde os direitos políticos aos civis e sociais e vice-versa. Tratou-se de uma dialética: tornar-se forte em uma esfera de direitos para lutar pela conquista de direitos em outras esferas ${ }^{124}$. Esta possibilidade, que se origina na acessibilidade dos direitos políticos, não existe sob um regime autoritário; ela somente é possível numa democracia política, por meio dos direitos políticos que esta estabelece inclusive para os que têm seus direitos sociais e civis truncados.

Por certo, a pobreza e a desigualdade extremas, e os padrões de autoritarismo social e exploração que se constroem sobre elas, colocam obstáculos formidáveis para o desenvolvimento deste processo dialético ${ }^{125}$. A este respeito tenho uma sugestão que reconheço insuficiente e que é, no, melhor dos casos, de médio prazo: colocar mais ênfase do que se tem colocado até hoje na América Latina nas lutas pela expansão dos direitos civis. Por quê? Pois precisamente porque qualquer direito civil que é conquistado pode se converter em uma importante alavanca para avançar a democratização política e na conquista de direitos sociais. Os direitos civis não somente protegem, também dão poder; eles geram resguardando-os legalmente - oportunidades de atuar para alcançar mais direitos. Os diretos

\footnotetext{
${ }^{124}$ Este mesmo argumento apresentado no PNUD (2008, p. 8).

${ }^{125}$ Este tema é fortemente realçado por Karl en seus comentários; mas me parece que ela exagera em uma formulação cuja rigidez parece fechar todo caminho possível.
} 
civis tornam assim possível (mas insisto: somente possível), para diversos atores individuais e coletivos, definir autonomamente sua identidade e interesses. Por sua vez, um importante fator que facilita estas lutas desde e para os direitos civis é previsto pelos direitos políticos lembre-se: expressão, associação, movimento - que um regime democrático não pode senão sancionar e em grau considerável (sob pena de perder seu próprio caráter democrático) respaldar. A extensão exitosa de direitos civís inicialmente baseada no uso de direitos políticos tende também a revigorizar a estes, o que por sua vez, abre a possibilidade de novas lutas por outros direitos, incluindo os sociais. Como o PNUD, entre outros, tem insistido ${ }^{126}$, estes direitos - políticos, civis e sociais são analiticamente separáveis, mas na prática se pressupõem mutuamente, e geralmente os avanços de qualquer deles tornam possível que outros também avancem. As conquistas em direitos civis, ou em direitos sociais, ou em diretos políticos, são valiosas per se porque são plataformas para a conquista de outros direitos.

Parece-me que o complicado processo que surge do anterior é o único caminho aberto para América Latina. É, insisto, um caminho aberto somente em regimes democráticos. Atravessar esta rota não será fácil, é algo que mostra entre outros indicadores, o fato de que em nossos países a agenda pública tem sido monopolizada por temas de política econômica (definidos, além do mais, de um modo tecnocrático e especialmente regressivo ${ }^{127}$ ), por escândalos de corrupção e por diversos tipos de violência. Para piorar, as reações governamentais à violência social frequentemente vão em direção a restringir ainda mais os direitos civis do setor popular. As privações provocadas pela falta desses direitos sociais raramente alcançam a agenda pública, exceto como problemas a serem resolvidos pela polícia, ou por circunstanciais - e humilhantes - dádivas oferecidas a segmentos em geral clientelisticamente selecionados) do setor popular ${ }^{128}$.

Vimos que, com poucas exceções, em termos de desenvolvimento humano e de direitos humanos, escasso progresso (e algumas regressões) tem se conseguido na América Latina sob os atuais regimes democráticos. Esta afirmação requer, no entanto, duas ressalvas. Uma é que em algumas dimensões de direitos sociais (tais como alfabetismo, escolaridade e mortalidade infantil) alguns países têm melhorado seus indicadores. A segunda é que, ao menos no nível agregado e em médio e longo prazo, a democracia política tem consequências. Adam Przeworsky e seus colaboradores realizaram um importante estudo que incluiu a todos

\footnotetext{
${ }^{126}$ Ver especialmente PNUD (2000).

${ }^{127}$ Meu colega Conaghan em seus comentários o expressa bem: "Las políticas que promueven el desarrollo democrático y el económico no pueden y no deben ser segregadas [...] Por buenas razones, la gente es escéptica acerca de la democraticidad del sistema cuando esenciales decisiones que afectan su calidad de vida son impuestas por gobiernos que responden a las presiones de las instituciones financieras internacionales."

${ }^{128}$ Segundo meu colega Iazzetta diz em seu comentário a este texto "la triste paradoja de un cielo políticamente incluyente aunque socialmente excluyente".
} 
os países do mundo para os quais existem dados razoavelmente confiáveis. Classificaram dicotomicamente esses países como democráticos ou autoritários. Sobre esta base, se perguntaram se esses regimes podem dar conta de diversos resultados, ao longo de uma série de dimensões. Alguns resultados foram negativos, (por exemplo, as taxas de crescimento econômico de países com regimes democráticos e autoritários são semelhantes), mas em outras descobertas são significativas, e, por certo, vale a pena destacá-los. Em particular,

[Em comparação com os regimes autoritários] las democracias, tienen bajas tasas de natalidad y mortalidad. Las mujeres, en las democracias tienen menos niños. Más niños llegan a la edad adulta. Como adultos, viven más tiempo, más años [... e] el efecto del régimen en la expectativa de vida es asombroso: $\mathrm{La}$ diferencia observada es enorme en cada nivel de ingreso" ${ }^{29}$.

Além do mais,

La mortalidad infantil promedio es muy superior bajo las dictaduras. [por sua vez] los gastos en educación [que segundo esse mesmo estudo são maiores nas democracias, $\mathrm{O}$ 'D] hacen decrecer sensiblemente la mortalidad bajo ambos regímenes [e o mesmo acontece com as despesas em saúde, que nas democracias são mais do que o dobro no autoritarismo: 3,3\% e 1,5\% do PIB, respectivamente, $\left.\mathrm{O}^{\prime} \mathrm{D}\right]^{130}$.

Por último,

El efecto de regímenes políticos sobre las vidas de las mujeres es indudable [...] Bajo las dictaduras las mujeres salen a trabajar fuera de casa con la misma frecuencia que bajo la democracia. Pero crian mucho más niños, ven morir a una mayor cantidad de ellos y tienen, ellas mismas, mayor probabilidad de muerte [precoce]" ${ }^{, 31}$.

De modo que a democracia política tem consequências, em termos de varias dimensões diretamente conectadas com os direitos sociais e o desenvolvimento humano (esta pesquisa não considerou indicadores diretamente relevantes para os direitos humanos). No entanto, ao menos, até o momento, estas consequências benéficas são escassamente visíveis na

\footnotetext{
${ }^{129}$ Przeworski et. al. (2000, p. 264).

${ }^{130}$ Ibid. p 237-239.

${ }^{131}$ Ibid. p. 265.
} 
América Latina: ademais, em algumas das dimensões mencionadas por Przeworsky et. al., em vários países parecem ter acontecido retrocessos ${ }^{132}$.

É claro que enfrentamos uma dura tarefa. Por certo, o setor popular dificilmente poderá ter sucesso sozinho. Como mínimo, precisa um estado aberto e "amigo", não - como ocorre frequentemente - fechado e hostil. É indispensável que se levem a cabo esforços para reforçar o estado, não somente no sentido de fazê-lo mais eficaz, mas também de torná-lo mais consistente com a condição de agentes de todos seus moradores. Isto é certo não somente para as instituições do estado, mas também, para o sistema legal, por duas razões. Uma é que ainda é necessário sancionar alguns direitos, como o demonstra a subsistência de regras discriminatórias contra as mulheres e diversas minorias, bem como de praticas policiais e judiciais que implicam em grosseiras violações dos direitos humanos do devido processo.

A segunda razão é de que muitos dos direitos existentes devem ainda ser implementados; na América Latina sabemos bem que as leis podem não ser mais do que um pedaço de papel. Para superar este legado não somente se necessitam melhores leis e melhores tribunais. Como foi visto na seção VI, é também necessária uma rede de instituições estatais, nacionais e subnacionais, comprometidas em aplicar não somente qualquer lei, mas um sistema legal democrático $^{133}$. Se, como tenho argumentado, a democracia política e seus direitos são bens públicos, é nosso dever moral e político ajudar o setor popular a usar as alavancas de esses direitos para alcançar outros; qualquer conquista nessas matérias prepara "as armas dos fracos" para suas lutas posteriores ${ }^{134}$.

Certamente foi notado que até agora tenho dito pouco sobre outro importante desafio: superar pelo menos as mais prementes necessidades de direitos sociais e desenvolvimento humano do setor popular. Isto se deveu a minha convicção de que, para alcançar isto, desfrutar direitos políticos, junto com importantes avanços nos direitos civis, é muito importante. Do contrário, as políticas contra a pobreza e desigualdade continuarão sendo capturadas, distorcidas, por persistentes práticas de clientelismo e paternalismo. A democracia e seus

\footnotetext{
${ }^{132} \mathrm{O}$ tom destas afirmações é tentativo porque sobre estas questões estão pendentes na América Latina importantes esforços de coleta de dados. Ao menos, seria importante recolher e compatibilizar a grande quantidade de informação existente em diversas instituições privadas, estatais e internacionais.

${ }^{133}$ Neste sentido vale a pena considerar a salvaguarda proposta por minha colega Karl em seus comentários, no sentido de que "Un ciclo positivo y auto-reforzante, por más prometedor y moralmente satisfactorio que sea, no puede darse por descontado. Esto es especialmente cierto cuando la construcción del estado de derecho debe estar dedicada a reformar, redefinir y promover los intereses de la amplia mayoría de la población en sociedad sumamentes desiguales - y no solo el estatus de las empresa mediante reformas de la ley comercial o la protección de los intereses de los propietarios mediante la ley penal".

${ }^{134}$ Scott (1985). O argumento original sobre os usos positivos da lei nas lutas do setor popular é Thompson (1975).
} 
direitos são importantes, provavelmente, são condições necessárias - para produzir avanços no desenvolvimento humano que não sejam facilmente reversíveis nem afundem os setores populares em maiores dependências clientelísticas. Talvez, no transcurso do processo dialético que tenho esboçado, surjam atores políticos e sociais capazes de desenhar, e apoiar, alternativas que atualmente não podemos vislumbrar ${ }^{135}$. Para que isto ocorra, não devemos esquecer, nem menosprezar, o fato que nos regimes democráticos atualmente existentes na América Latina, os direitos políticos são os únicos que o setor popular goza mais ou menos completamente.

\section{CONVERGÊNCIAS E SUPOSIÇÕES}

"Nadie [...] puede gozar plenamente ninguno de los derechos que supone que tiene si le falta lo esencial para una vida razonablemente saludable y activa"136. Em consequência, "es incoherente reconocer derechos referidos a la vida o la integridad física cuando los medios

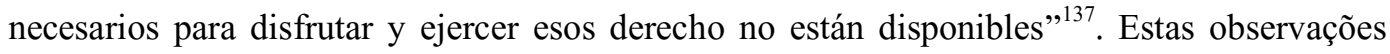
são tristemente óbvias. Elas se referem - no âmbito do desenvolvimento humano, dos direitos humanos e, por certo, dos direitos políticos - às capacidades que tornam possível, ou impedem, a agência. Pela mesma razão que comentei quando discuto os direitos políticos, este tema é teoricamente indecidível no que se refere a qual seria o conjunto mínimo suficiente em termos de desenvolvimento humano e de direitos humanos. Onde, e sobre a base de que critérios, poderíamos traçar uma linha clara e firme por cima da qual poderíamos supor razoavelmente habilitada à agência nos termos que se concebem as concepções do desenvolvimento humano e os direitos humanos? Como ocorre com os direitos políticos, não há, e nunca haverá um consenso intersubjetivo firme e generalizado em relação a qual seria um conjunto mínimo suficiente dos respectivos direitos e capacidades. Portanto, da mesma, maneira que ocorre com os direitos políticos, ao invés de tratar de estabelecer artificialmente os respectivos limites externos e internos dessas capacidades e direitos, o procedimento apropriado é analisar as razões e as consequências de sua indecidibilidade.

Antes de avançar nesta direção, quero ilustrar meu argumento com um par de exemplos das oscilações e ambiguidades que provocam as tentativas de fixar artificialmente esses limites, que vão desde a confecção de listas "minimalistas" que são inevitavelmente criticadas como insuficientes até a elaboração de longas listas que são não menos inevitavelmente criticadas por incluir praticamente tudo de bom que alguém pode querer para

\footnotetext{
${ }^{135}$ Em O’ Donnell (1999; 2001b) discuto algumas possíveis coalizões políticas vinculadas a este tema.

${ }^{136}$ Shue (1996, p. 7, itálico no original).

${ }^{137}$ Vázquez (2001, p. 102).
} 


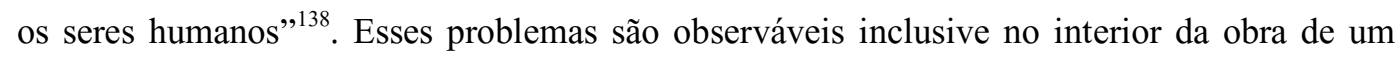
mesmo autor(a). Aqui menciono dois que, por boas razões, são muito influentes nos seus respectivos campos, direitos humanos e desenvolvimento humano respectivamente. Henry Shue afirma que há alguns "derechos estratégicamente fundamentales"139, necessários "para disfrutar de todos los otros derechos", que são os direitos a "seguridad, subsistencia y libertad" "140. No entanto, a medida que Shue desenvolveu sua análise vai agregando outros direitos que percebe como necessários paraum conjunto mínimo suficiente ${ }^{141}$. Por outro lado, em termos de desenvolvimento humano, Martha Nussbaum avança na direção oposta. Começa com uma complexa lista de "capacidades funcionais básicas dos indivíduos" "No entanto, compreendendo sem dúvida que esta lista é demasiadamente extensa, Nussbaum a "minimiza" estabelecendo que existem duas capacidades ("a razão prática e a associação") que são ainda mais centrais, "ya que ambas organizan y cubren todas las otras, volviendo verdaderamente humano su ejercicio" $" 143$.

Apesar dessas oscilações, esses e outros autores me sugerem dois argumentos. Um é que as versões minimalistas dessas listas são insuficientes para garantir plenamente os bens propostos pelo desenvolvimento humano, os direitos humanos ou a democracia; sempre é possível nomear outro direito ou capacidade em relação ao qual pode se argumentar que também é necessário(a) para habilitar a agência em qualquer destes três planos. $O$ segundo argumento é que, como as listas extensas apresentadas por Shue e Nussbaum (bem como pelo PNUD) ${ }^{144}$ incluem direitos e capacidades evidentemente muito importantes, se costuma afirmar que os direitos e/ou capacidades enunciados nestas listas são "igualmente

\footnotetext{
${ }^{138}$ De fato, este tipo de crítica foi realizado, a meu juizo com razão, com relação aos Informes sobre o Desenvolvimento Humano.

${ }^{139}$ Shue (1996, p. 197).

${ }^{140}$ Ibid. p. 20 e passim.

${ }^{141}$ Ibíd. p. 65 e passim. Entre estes direitos se encontram os direitos à participação, à liberdade de movimento físico, ao devido processo ao tratamento justo, e outros.

${ }^{142}$ Nussbaum (2000b, p. 12). Estas capacidades, que a autora considera também como direitos, são (Ibíd. p. 7880; 1997, p. 287-289) aptidões para (os direitos a) "la vida, la salud física, los sentimientos, la imaginación y los pensamientos, las emociones, la razón práctica, la asociación, la recreación y el control sobre el médio ambiente" (alguns destes direitos tem suas próprias categorias); ademais, esta autora distingue entre capacidades "básicas, internas y combinadas" (2000b, p. 84-85).

${ }^{143}$ Ibid. p. 79 e 82.

${ }^{144}$ PNUD (2000, p. 7) começa com uma lista bastante concisa ("las três condiciones esenciales son que las personas tengan uma vida larga y saludable, que sean [socialmente] reconocidas y que tengan acceso a los recursos necesarios para un nivel de vida decente"). No entanto, ao longo do relatório esta lista é consideravelmente ampliada com uma série de outras capacidades e direitos. Veja-se, por exemplo, Ibid.: p. 2, 8, 19 e 77 .
} 
fundamentais" ${ }^{145}$. Esta afirmação é muito problemática, em parte porque se corre o risco de nos deixar sem um guia pratico e analítico e, em parte porque oferece um fácil alvo para os que negam a relevância prática e/ou a importância conceitual da própria problemática do desenvolvimento humano, dos direitos humanos e de uma teoria da democracia que vá além dos limites do regime. Outro problema com estas listas de bens "igualmente fundamentais" é que podem ser desalentadoras: Por onde começar se há tantas violações e privações de tantos direitos e capacidades tão estreitamente ligados?

A esta altura pode estar claro porque encarei acima uma minuciosa discussão dos direitos políticos. Meu propósito foi justificar duas afirmações: uma, que o conjunto mínimo suficiente desses direitos é teoricamente indecidível; e outra, que esses direitos (de expressão, associação, movimento e outros desse tipo) são na realidade segmentos de mais amplos - e mais antigos - direitos civis ${ }^{146}$. Argumentei, da mesma maneira, que esses direitos pertencem a todos os seres humanos na medida em que os reconhecemos como agentes, e que seus direitos como tais agentes na esfera política dificilmente podem ser exercidos se os indivíduos carecem das capacidades "básicas" aos que se referem os direitos humanos ${ }^{147}$. Convém voltar ao meu argumento inicial em relação ao terreno importante que compartilham a democracia, os direitos humanos e o desenvolvimento humano: eles compartilham, como o fundamento mesmo de suas respectivas perspectivas, uma concepção moral do ser humano como um agente, e os três propõem que isto gera não só reivindicações morais, mas também direitos positivos universais, por mais indecidivel que seja o conjunto mínimo suficiente dos respectivos direitos e capacidades.

Um ser dotado de razão prática tem direito a ser respeitado na sua condição e consequente dignidade enquanto tal; sem também o direito a provisão social das condições necessárias para o livre exercício dos aspectos cognitivo, morais, sociais e políticos adequados a sua condição de agente. Submeter este indivíduo a, digamos, violência física ou insatisfação de necessidades materiais básicas, ou negar sua cidadania política, são todas maneiras severas de negar essa condição. Esta visão universalista da agência e seus direitos estão explicita na tradição dos direitos humanos, pela definição mesma de seu tema. No que diz respeito a democracia, estabeleci que inclusive considerando somente um dos seus aspectos, o regime, podemos perceber sua forte - embora geralmente implícita - vinculação com a concepção dos

\footnotetext{
${ }^{145}$ Ibíd. p. 12 e passim para esta expressão e similares.

${ }^{146}$ Como se lembrará, argumentei que nos países iniciadores estes direitos se efetivarão como direitos civis antes de ser "promovidos" à condição de direitos políticos. Também observei que, obviamente, estes direitos são exercidos em muitos âmbitos da sociedade, para alem do regime.

${ }^{147}$ Habermas (1999, p. 332) o diz bem: "Sin derechos básicos que aseguren la autonomia privada de los ciudadanos, tampoco habrá ningnun médio para la institucionalización legal de las condiciones bajo las cuales estos ciudadanos podrían hacer uso de su autonomia pública”.
} 
indivíduos como agentes. Em relação com o desenvolvimento humano, seu foco nas capacidades somente pode ser entendido a partir dos funcionamentos que elas permitem e, ao fazê-lo, habilitam a agencia de cada individuo. Esta fundamentação e seu universalismo são explícitos no trabalho de Sen e na frase com que começa o Relatório sobre o Desenvolvimento Humano 2000: "Los derechos humanos y el desarrollo humano comparten una misma visión y un propósito común: asegurar la libertad, el bienestar y la dignidad de todas las personas en todas partes" $" 148$.

Os direitos e capacidades postulados por essas três correntes se referem diretamente apontam a habilitar - à agência ${ }^{149}$. Este é o nexo central e compartilhado dessas três correntes. Esta é também a razão pela qual cada uma, ou uma combinação de duas delas, "empurra" a conquista de outra(s). Observamos que nos países pioneiros a precoce realização de direitos civis (que continham um importante conjunto de direitos humanos) e, depois de direitos políticos, facilitou a conquista de direitos sociais (que por sua parte contém importantes elementos de desenvolvimento humano). No entanto, como vimos em relação à América Latina, a respeito destas questões não há sequências histórica ou mecanicamente predeterminadas. Outros exemplos são oferecidos por alguns países da Ásia Oriental - Japão, Coréia do Sul e Taiwan - que exibem uma sequência que difere tanto da dos países pioneiros como os da América Latina: esses países primeiro alcançaram um grau bastante elevado de desenvolvimento humano e somente depois adquiriram direitos políticos e, em menor medida, civis.

Em parte porque o fundamento comum destas três correntes não tem sido analisado, sabemos pouco sobre relações causais pelas quais conquistas em algumas destas dimensões empurrariam ou facilitariam avanços em outras. Porem dado esse fundamento comum e generalizações históricas como as que ainda muito sinteticamente, apresentei acima, me parece claro que se pode afirmar que entre estas três correntes existe, pelo menos, uma forte afinidade eletiva ${ }^{150}$.

Ademais tal como ocorre com os direitos políticos - os direitos e capacidades postulados pelos direitos humanos e o desenvolvimento humano somente podem ser

\footnotetext{
${ }^{148}$ PNUD (2000, p. 1).

${ }^{149}$ Isto é óbvio no caso dos direitos humanos pela definição mesma de seu tema. Com relação ao desenvolvimento humano, a mesma concepção, ainda que menos explícita, pode ser detectada em afirmações como "El desarrollo humano [...] es un proceso de mejoramiento de las capacidades humanas - de ampliación de las opciones y de las oportunidades para que cada persona pueda llevar una vida respeto y dignidad", PNUD (2000, p. 2).

${ }^{150}$ No sentido originariamente utilizado por Goethe, do qual Weber tomou emprestada esta metáfora: dois ou mais componentes que não se causam um ao outro, mas que exercem uma forte e - para usar um termo contemporâneo - sinérgica influência mútua.
} 
indutivamente derivados; em consequência, seu conjunto mínimo suficiente ${ }^{151}$ também é teoricamente indecidível. Por outro lado, e como vimos com os direitos políticos, cada uma das capacidades e direitos que parecem razoáveis candidatos a serem considerados "básicos" para o desenvolvimento humano e os direitos humanos, é de suma importância, e como tal deveriam ser considerados empiricamente e tematizados teoricamente.

\section{Lutas passadas e presentes}

A simultânea impossibilidade de decidir e relevância dos direitos e capacidades que discuti na seção anterior constituem - reconheçamos - um problema complexo. Uma alternativa é proceder, como fiz com alguns exemplos sobre os direitos políticos, a contrario sensu, identificando condições de privação tão extremas que deixam poucas dúvidas a respeito da negação da agência em termos de desenvolvimento humano ou direitos humanos. Esse é um avanço útil, porém, é uma determinação negativa que não diz nada sobre, a partir de que ponto, as opções que efetivamente habilitam a agência são satisfeitas. Além disso, os critérios relevantes para o desenvolvimento humano, para os direitos humanos e para a democracia, foram se modificando ao longo do tempo. Inclusive nos países pioneiros essa variabilidade histórica gera problemas complexos na hora de determinar um conjunto satisfatório de direitos mínimos; obviamente, é ainda mais difícil determinar esse conjunto para países que possuem recursos mais escassos do que os anteriores.

Tudo isso certamente é um tormento para uma mente geométrica. No entanto, podemos avançar alguns passos por meio da discussão de algumas contribuições recentes. Sen fez a interessante observação de que, inclusive em relação a teorias com inclinação conservadora:

Puede ser útil preguntar por qué [atualmente, O’D] tantas teorías muy
diferentes sobre la ética social tienen la característica común de demandar la
igualdad de algo [...] Es también de gran interés práctico observar que la
imparcialidad y el trato igualitario, en una forma u otra, proveen una plataforma
compartida por todas las propuestas éticas y políticas que tiene alguna vigencia
actual [...] Si el argumento que la desigualdad en algún espacio significativo es
justa (o buena, o aceptable o tolerable), esto debe ser racionalmente defendido
[...] [quando este é o caso, O'D] el argumento adopta la forma de demonstrar

\footnotetext{
${ }^{151}$ Lembre-se que defini este conjunto mínimo suficiente como os direitos que seriam necessários (e em conjunto suficientes) para garantir a existência e institucionalização de um regime democrático. Lembre-se também que discuti as razões que tornam impossível alcançar um acordo teórico e/ou intersubjetivo generalizado para uma definição clara e firme deste conjunto.
} 
que esa desigualdad es consecuencia de la igualdad en otro espacio, considerado más importante que el anterior ${ }^{152}$.

A inevitabilidade de prescrever algum tipo de igualdade, inclusive por parte das teorias conservadoras, é uma conquista contemporânea. Durante longo tempo muitas teorias defenderam uma desigualdade intrínseca entre os seres humanos; como observei num contexto diferente - mas, convergente - os servos, os trabalhadores, as mulheres e muitos outros atores foram considerados carentes de agência e, portanto, intrinsecamente inferiores aos seus "superiores". Suspeito que a tendência das teorias éticas contemporâneas a basear-se - como observa Sen - em alguma dimensão de igualdade humana é uma reverberação do processo histórico de expansão da atribuição de agência em numerosos espaços sociopolíticos. Apesar dos horrores do século passado, esta caracterização de que todos os indivíduos somos essencialmente iguais é uma conquista importantíssima. Consequentemente, a ideia universalista de agência postulada ao mesmo tempo pelas perspectivas do desenvolvimento humano, dos direitos humanos e - como argumentei - também da democracia, já não é um argumento estranho ou isolado no mundo contemporâneo - falta, é claro, tirar as poderosas e mobilizadoras consequências que decorrem disso. Por outro lado, não creio que a igualdade universal que estas correntes pregam possa ser desafiada pelo relativismo cultural extremo hoje em voga em alguns espaços ${ }^{153}$. Inclusive nos países onde, como ocorre na América Latina, na prática essa igualdade é negada de muitas formas, a perspectiva igualitarista associada a seus regimes democráticos e sistemas legais (isto é, de uma agência universalmente atribuída) está presente, pronta para ser mobilizada a serviço da conquista de outros direitos ainda ausentes.

As observações precedentes passam por cima de várias discussões filosóficas e éticas centradas na igualdade e suas contraposições (trade offs) com a liberdade. Esses são temas muito complicados, que provocam e seguirão provocando árduas discussões teóricas e conflitos políticos. Não posso dedicar-me a isso no presente texto. Aqui estou considerando situações que são, num sentido importante, anteriores a essas discussões. No Noroeste, essas discussões habitualmente enfrentam a questão de quais princípios de liberdade e/ou igualdade deveriam regular a distribuição de bens sociais uma vez que todos, ou a maioria, tenham

\footnotetext{
${ }^{152}$ Sen (1992, p. 17-21, itálico no original).

${ }^{153}$ Não tenho espaço aqui para discutir este tema complexo. É possível encontrar sólidos argumentos contrários ao anti-universalismo característico do relativismo cultural extremo em Franck (2001), Garzón Valdés (1993), Nussbaum (2000b), Sen (1999a; 1999b; 2000b) e Stepan (2000). Ver também Touraine (1997, p. 206): "No hay sociedad multicultural posible sin principios universales que permitan la comunicación entre individuos y grupo social y culturalmente diferentes".
} 
atingido um patamar básico de direitos e capacidades ${ }^{154}$. Nas situações às quais estou me reportando, por outro lado, o principal problema se refere aos indivíduos (muitos) que não têm acesso a esses direitos e capacidades básicas. Disso advém a pergunta de se, na América Latina e noutras regiões do Sul e do Leste, existem - antes que possa ser proposto, em condições de abundância, o problema das contraposições entre liberdade e igualdade - boas razões para afirmar o direito a alcançar um nível - ou uma base - mínimo de direitos e capacidades. Acredito que essas razões existem e que seu fundamento está no reconhecimento da agência de todo ser humano. Essas razões referem-se a um aspecto primário da equidade: não igualdade plena, senão igualdade básica. Dessa forma me refiro ao direito da cada um pelo menos a dois bens: primeiro, como foi visto quando abordamos o tema das instituições estatais (mas agora de uma forma mais geral), ser tratado com a equidade e consideração devidas a um agente; e segundo, alcançar uma base de benefícios sociais que inclua um conjunto básico de direitos e capacidades - opções - que habilitam a agência ou que, pelo menos, impedem que sofram privações que claramente a truncam ${ }^{155}$.

Acima desse nível podemos, e devemos, ter complexas e - por que não? apaixonadas discussões; no entanto, qualquer que seja o resultado das mesmas, permanece aberta a questão de que a reivindicação de um conjunto básico de direitos e capacidades que fazem possível a agência não é somente uma aspiração moral, mas um direito positivo. Retornarei a esse tema. Antes disso chamo atenção sobre outra contribuição de Sen. Ele argumenta que:

La participación política y social [democrática] tiene valor intrínseco para la vida y el bienestar humanos [assim como] valor instrumental para ampliar la audibilidad de los reclamos populares de atención política [incluindo as demandas por necesidades economicas $]^{156}$.

\footnotetext{
${ }^{154}$ Nesse mesmo sentido, Dasgupta (1993, p. 45) observa: "Buena parte de la ética contemporánea parte de suponer que estas necesidades [básicas] han sido satisfechas”. Esta suposição é explicita no texto de filosofia política que certamente tem sido o mais influente nas últimas décadas, pelo menos no mundo anglo-saxão (RAWLS, 1971, p. 152, 542-543); segundo este autor, sua teoria de justiça só pretende ser aplicada em países onde "sólo las menos urgentes necesidades materiales no han sido todavía satisfechas"; para uma reiteração recente desta posição ver Rawls (2001). Por sua vez, ainda que menos explicitamente, a mesma pressuposição está implícita no trabalho de Habermas, provavelmente o mais influente filósofo político europeu continental (ver, por exemplo, minha referência anterior a Habermas, 1999). O problema que fica pendente é o de que podemos dizer sobre os países - incluindo os que possuem regimes democráticos - que não satisfazem esse pressuposto.

${ }^{155}$ Isto é o que a Auditoria (2001) chama corretamente de "habilitação cidadã mínima".

${ }^{156}$ Sen (1999a, p. 10, itálico no original).
} 
Sen agrega que a democracia também tem valor construtivo por que:

Hasta la idea de 'necesidades' - incluyendo el significado de las 'necesidades económicas' - requiere discusión pública e intercambio de información, perspectivas y análisis [...] Los derechos políticos, incluyendo la libertad de expresión y discusión, no son sólo fundamentales para la elaboración de respuestas sociales a las necesidades económicas: son centrales, también, en la propia conceptualización de esas necesidades económicas ${ }^{157}$.

Podemos vincular essas observações com minha discussão sobre a indecidibilidade do conjunto de direitos intrínsecos à democracia. Sobre essa questão, Jeremy Waldron comenta que:

Cualquier teoría de los derechos deberá enfrentar desacuerdos acerca de los intereses que identifica como derechos, y de los términos en que lo hace [...] Además, las teorías de los derechos tienen que enfrentar controversias acerca de los tipos de obligación que los sustentan y los tipos de prioridad moral que establecen: obligaciones absolutas, obligaciones prima facie, prioridades lexicográficas, prioridades ponderadas, obligaciones derivadas de la posición del agente, prerrogativas de los agentes, etc. ${ }^{158}$.

O conteúdo dos direitos, seu grau de especificidade, seu alcance, a prioridade relativa de uns em relação a outros, as contraposições entre eles e as formas de resolvê-las, são e serão sempre questão de opinião: existem demasiadas perspectivas e preferências, demasiadas teorias sobre o que é justo ou equitativo e demasiados interesses e posições sociais para que essas questões possam ser clara e definitivamente resolvidas. Este é um fato da vida social que não deveríamos negar nem lamentar; é consequência do fato de que os indivíduos são agentes e que os agentes têm diversos projetos de vida, visões, ideologias, interesses e posições na sociedade.

Esse fato social primário se combina com um problema prático que tem sido destacado por outra contribuição recente ${ }^{159}$ : implementar direitos - praticamente qualquer direito - requer arranjos institucionais complexos, e esses arranjos custam esforços, tempo e dinheiro que, usualmente, são provenientes dos impostos. Por isso, não só devido à parcialidades ou negligência, alguns direitos não são implementados, outros são débil ou seletivamente implantados e, na prática, somente alguns são aplicados de forma mais ou

\footnotetext{
${ }^{157}$ Ibid. p. 11.

${ }^{158}$ Waldron (1999, p. 225-226).

${ }^{159}$ Holmes e Sunstein (1999). Ver também os comentários de Conaghan, Iazzeta e Tavares de Almeida.
} 
menos plena. Consequentemente, os direitos não são estáticos, mas "se están expandiendo y contrayendo constantemente bajo la presión de la acción legislativa y judicial”"160. Holmes e Sunstein apontam para um país rico - Estados Unidos - quando descrevem a seletividade da sanção e implementação de direitos que são resultantes de diversas restrições políticas, institucionais e econômicas. Por certo, essas pressões são tanto mais fortes (e mais enviesadas no seu conteúdo e possibilidade de êxito) quanto mais débil é o estado. Recapitulo a discussão anterior por meio de algumas proposições:

23. É tema de discussão inevitável, em qualquer circunstância histórica, quais os direitos, com qual intensidade, com que alcance e com que prioridade são os mesmos aprovados e implementados.

24. Esse fato é consequência de restrições institucionais e econômicas, mas também da diversidade social que advêm da agência humana e, portanto, das diversas perspectivas, estilos de vida, ideologias e interesses que os agentes representam, seja (estaticamente) num momento determinado, seja quando essas características se desenvolvem e se modificam (dinamicamente) no transcorrer do tempo.

Qual é a resposta para esses problemas e objeções? Bastante simples: democracia. A questão crucial, a grande questão política é quem, como e sobre quais bases se decidem quais direitos (e com que intensidade e alcance) são sancionados e implementados, enquanto outros não são ou não passam de letra morta. Ainda fundamentadas nas características universais dos seres humanos, as decisões a respeito de quais demandas se convertem em necessidades publicamente reconhecidas (direitos), até que ponto e como são implementadas e qual sua relação com outros direitos e obrigações, são uma construção política e social. Uma questão fundamental é quem e como participam dessa construção, incluindo certamente as demandas que são silenciadas ou postergadas e que não conseguem se converter em direitos ${ }^{161}$. Nesses debates e conflitos, o reconhecimento mútuo dos cidadãos como agentes é fundamental para a expansão de seus direitos e capacidades ${ }^{162}$. Esse reconhecimento gera um espaço público de participação política, amparado nos direitos que fazem parte de um regime democrático. É

\footnotetext{
${ }^{160}$ Ibid. p. 104.

${ }^{161}$ Sobre essa questão são pertinentes os comentários de Whitehead. Sua ênfase sobre o caráter socialmente definido dos direitos, com a qual estou de acordo, deveria dissipar a ideia de que a minha é uma versão de "individualismo liberal", como Karl parece temer nos seus comentários. Como já assinalei na nota de rodapé n. 2, que um dos níveis analíticos de uma teoria se centre sobre os indivíduos não a faz necessariamente individualista.

${ }^{162}$ Para Para uma interessante análise que acentua este aspecto, ver Ackerman (1980).
} 
nesse espaço onde, ao menos nos países pioneiros, várias demandas de trabalhadores, camponeses, mulheres e outros atores se transformaram em direitos. ${ }^{163}$ No entanto, já comentei que nesses países as lutas atuais em termos de diversas demandas pressupõem que quase todos estão acima de um piso básico de direitos e capacidades. Por certo, este não é o caso da América Latina e outras regiões do Sul e do Leste. Isso outorga especial urgência e dramatismo aos argumentos e conflitos sobre quais direitos deveriam ser sancionados e implementados nesses países, nos quais uma extensa pobreza e desigualdade põe em perigo a própria possibilidade de reconhecer a todos como agentes. Observei também que em vários dos nossos países, seja devido à repressão ou a severas privações sofridas pelos setores populares, suas demandas poucas vezes atingiram a agenda pública. Isso é um reflexo fiel da desigualdade desses países: poucas questões entram nessa agenda afora aquelas que interessam aos setores e classes dominantes, exceto as referidas à "segurança pública", que com frequência implicam na criminalização da pobreza e, por conseguinte, em novos retrocessos nos direitos civis dos setores populares.

Paradoxalmente, nos países onde é mais necessária uma ampla discussão sobre diversas demandas é onde é mais difícil incorporá-las à agenda pública. A consequente surdez para com esta agenda é uma indicação da baixa qualidade dessas democracias e sugere fortemente que muitos dos que são cidadãos políticos carecem de direitos e capacidades sociais e civis básicas.

Já sugeri que a resposta diante desta situação é mais e melhor democracia. Os direitos da cidadania política, somados aos direitos civis que possam existir em cada caso, além das alianças políticas pertinentes, devem ser o ponto de partida para uma inevitavelmente longa e árdua empreitada. Curiosamente, o principal tema dessa empreitada talvez seja aquele que, segundo argumentei, é teoricamente indecidível: Qual deveria ser o "mínimo social decente" $164 \mathrm{em}$ termos de um conjunto básico de capacidades de desenvolvimento humano e de direitos humanos? Além disso, se um país é pobre e tem um estado anêmico e um sistema legal truncado, quais seriam as trajetórias adequadas para atingir esse mínimo ${ }^{165}$ ?

\footnotetext{
${ }^{163} \mathrm{O}$ estudo comparado fundamental sobre estes temas é Rueschemeyer et. al. (1991); especificamente para América Latina e o movimento trabalhista ver principalmente Collier e Berins Collier (1991). Ver assim mesmo Huber et. al. (1997) e Huber e Stephens (1999).

${ }^{164}$ Nussbaum (2000a, p. 125).

${ }^{165}$ Como Tavares de Almeida apresenta em seu comentário, inclusive dentro da América Latina há importantes variações neste aspecto, que deveriam ser levadas em conta quando se consideram possíveis sequências e trajetórias. Por certo, este importante problema excede as possibilidades do presente texto, mas não quero deixar de mencionar que, qualquer que seja a pobreza de recursos de um dado país, isso não deveria impedir que sejam traçados horizontes temporais dentro dos quais $\mathrm{N}$ capacidades e direitos básicos deveriam ser alcançados.
} 
Como a essa altura já deveria estar claro, não podemos conhecer antecipadamente as respostas para estas perguntas. No entanto, pelo menos sabemos que, da mesma forma como foi visto em relação aos direitos políticos, é possível derivar indutivamente e a contrário sensu condições que, para além de qualquer dúvida razoável, bloqueiam a agência, seja esta definida em termos de direitos humanos ou de desenvolvimento humano. Ser vítima de violência física ou do medo habitual à mesma, ou padecer de fome ou desnutrição, ou estar exposto a sérias doenças preveníveis são, entre outras que poderíamos incluir, fortes candidatas a ser consideradas privações de direitos e capacidades básicas.

Chegamos num ponto que quero enfatizar. Em relação aos direitos políticos, a indecidibilidade em termos de seu conjunto de direitos mínimos suficientes não nos impediu de identificar alguns direitos (como, repito, os de expressão, associação e movimento) sobre os quais podemos desenvolver uma proposição empírica, indutivamente derivada: se esses direitos estão ausentes ou se são severamente restringidos, então um regime democrático e seu componente de cidadania política não existem. Nesse mesmo sentido, a impossibilidade de determinar um conjunto mínimo que seja suficiente para o desenvolvimento humano e os direitos humanos não deveria nos impedir de identificar, com confiança, condições que, tendo como base o conhecimento disponível ${ }^{166}$, representam severas restrições à agência. Por exemplo, em termos de desenvolvimento humano, os biólogos conhecem bastante bem os requisitos nutricionais mínimos de diversos grupos sociais, bem como as trágicas consequências que a privação desses respectivos mínimos acarreta para suas vítimas e seus descendentes ${ }^{167}$. Em termos de direitos humanos, digamos, podemos identificar práticas de violência doméstica ou de tortura policial e outros severos maus tratos que claramente negam a agência dos indivíduos sujeitos a esses males.

Felizmente, nos dias atuais existem diversas instituições - públicas, privadas e internacionais - que coletam informação relevante sobre esses temas; penso que chegou a hora de que algumas instituições tomem a dianteira na coordenação da coleta e compatibilização

\footnotetext{
${ }^{166}$ Como já fiz em relação aos direitos políticos, mas com o alerta de que para o desenvolvimento humano e os direitos humanos os conhecimentos requeridos são mais variados e complexos: não só a lei e a ciência social, mas também conhecimentos médico/biológicos e psicológicos são necessários para estabelecer, por exemplo, as consequências de diversas privações ou violências materiais.

${ }^{167}$ É possível encontrar dados e discussão sobre a situação lamentável da América Latina neste e outros aspectos em Baterll e (Alejandro) O’Donnell (2000). Para uma visão geral, ver Dasgupta, quem comenta (1993, p. 474): "Se dice a menudo que incluso cuando una persona no tiene bienes físicos, tiene un bien que es inalienable, y que es su fuerza de trabajo. He realizado el importante descubrimiento de que esto es falso. La transformación de la fuerza de trabajo potencial en trabajo real sólo puede ser realizada si la persona encuentra los medios necesarios para esto" (itálico no original).
} 
desses dados ${ }^{168}$. De qualquer forma, devemos advertir que as necessidades e carências que aqui são importantes não são apenas o sofrimento de indivíduos isolados; são questões sociais que deveríamos enfrentar em termos do reconhecimento de responsabilidades coletivas e públicas $^{169}$.

Sustentando-se na evidência desse tipo de privações e suas consequências, é possível argumentar convincentemente que os recursos de um país deveriam ser destinados, em primeiro lugar, a mitigá-las. No entanto, podemos ter a segurança de que na contramão desta posição serão propostos argumentos alternativos como, por exemplo, que seria preferível dedicar esses recursos para melhorar os serviços de saúde e educação para os setores médios, a fim de que uma força de trabalho melhor treinada e mais saudável contribua para um desenvolvimento econômico que presumivelmente beneficiará também aos que sofrem as privações mais severas. Isso mostra que estas são questões fundamentalmente políticas, baseadas em diferentes valores, ideologias e posições sociais, e em teorias mais ou menos elaboradas sobre o funcionamento de uma determinada sociedade e, nos dias atuais, e cada vez mais, também a respeito do funcionamento do mundo inteiro. As discussões, conflitos e alianças ao redor dessas questões determinam quais são as necessidades "reais" (isto é, socialmente definidas) que um país decide satisfazer, ignorar ou reprimir.

A política - inclusive, por certo, a política democrática - é ao mesmo tempo conflito e consenso. Introduzir na agenda pública temas estreitamente associados às desigualdades sociais existentes, argumentar que certas necessidades são direitos positivos que podem ser esgrimidos frente ao estado e à sociedade, e debater a respeito das prioridades relativas de diferentes tipos de direitos e capacidades, todos estes são temas conflitivos, tanto mais conflitivos quanto mais desigual é uma sociedade e quanto mais habituados a suas mordomias estão seus setores e classes dominantes. Esta é uma realidade da qual não podemos escapar, especialmente nas democracias políticas que coexistem com sociedades sumamente desiguais; esquivar-se dela mediante concepções moderadamente consensualistas ou formalmente

\footnotetext{
${ }^{168}$ Os Relatórios sobre Desenvolvimento Humano do PNUD, nacionais e internacionais, são passos importantes nessa direção. Mas os dados que emergem deles necessitam ser inter-relacionados e compatibilizados; ademais, a cobertura desses dados é ainda bastante limitada. Por outro lado, impressiona-me a capacidade do Banco Mundial para coletar - por si mesmo ou comprando de maneira direta ou indireta - diversos tipos de dados. No entanto, muitos desses dados não estão disponíveis em sua forma original para análise de pesquisadores externos (diga-se de passagem, um importante tema de accountability), e a perspectiva sobre o desenvolvimento que orienta seus trabalhos é bastante diferente da que aplico aqui e da que se expressa nos Relatórios sobre Desenvolvimento Humano.

${ }^{169}$ Weale (1983, p. 35) insiste com razão sobre este ponto. Sobre esta base, propõe o que bem pode ser um critério de avaliação: "El criterio básico de un mínimo social [...] es que cuando el mismo es satisfecho, las personas deberían ser capaces de afrontar las obligaciones que convencionalmente se esperan de todos en la sociedad como productores, ciudadanos, vecinos, amigos y padres".
} 
centradas no regime implica sustentar de fato um status quo que, ao menos desde o ângulo dos direitos da agência, é inaceitável.

Vale a pena destacar, agora, uma interseção entre democracia, desenvolvimento humano e direitos humanos: exceto quiçá para alguns indivíduos verdadeiramente excepcionais, tal como vimos com o exemplo de Juana, o exercício de direitos políticos requer que algumas capacidades básicas tenham sido atingidas ${ }^{170}$ reciprocamente, as lutas para alcançar esses direitos e capacidades se beneficiam dos direitos universais que advêm da democracia política. Uma perspectiva pessimista diria que acabo de estabelecer um círculo vicioso. Uma perspectiva alternativa é consequência da dialética que esbocei na seção X. Ela reconhece a peculiar dinâmica e o caráter historicamente aberto da democracia e me permite enunciar outra proposição ${ }^{171}$.

25. A sempre possível extensão e retração dos direitos políticos, sociais e humanos e, abarcando todos eles, a grande questão - política e moral - dos direitos e capacidades que habilitam a agência, são o campo no qual, numa democracia, se jogou e se seguirá jogando a política.

\footnotetext{
${ }^{170}$ Existem alguns estudos empíricos de considerável interesse a este respeito. Em particular, Frohlich e Oppenheimer (1992) levaram adiante uma série de experimentos para estudar visões dominantes sobre a justiça distributiva. Solicitaram a (estudantes de graduação no Canadá, Polônia e Estados Unidos) que tentassem um acordo unânime a respeito de que princípio geraria "a mais justa distribuição de renda" numa sociedade na qual os sujeitos não conhecem de antemão qual posição lhes corresponderá ocupar (o "véu de ignorância" de Rawls 1971). Estes princípios eram: 1. "Maximizar o rendimento mínimo ou básico na sociedade"; 2. "Maximizar o rendimento médio" [o princípio de "máxima utilidade média" de Harsanyi, O’D); 3. "Maximizar o rendimento médio só após ter garantido que a diferença entre os indivíduos mais pobres e os indivíduos mais ricos [...] não supere uma medida determinada" (o "princípio de diferença” de Rawls 1971, O’D); 4. "Maximizar o rendimento médio só após ter garantido para todos certo mínimo especificado", ou 5. Qualquer outro princípio que os sujeitos quisessem formular (Ibíd:: p. 35 e passim). Os autores fizeram um total de 76 experimentos; um notável 78\% destes grupos esteve de acordo em escolher o critério 4 sem um teto; isto é, em estabelecer um mínimo garantido para todos e acima disso nenhuma restrição a respeito da possibilidade da cada um de ultrapassar omesmo (Ibid.: p. 59 e passim). Observe-se que isto é estritamente equivalente a optar pelos direitos e capacidades básicas que discuto neste texto. Ademais, Frolich e Oppenheimer informam que "a democracia era importante" em seus experimentos: quantos mais abertas e estendidas foram as discussões durante os experimentos, tanto mais firme e estável foi o apoio a este princípio. Remeto a esta obra para maiores detalhes. Para um meditado argumento a favor deste critério ver Waldron (1999).

${ }^{171}$ Em seus comentários Withehead observa corretamente que na América Latina qualquer direito que tenha sido conquistado é usualmente mais precário (e às vezes reversível) que nos países pioneiros.
} 
O enunciado da proposição anterior é a principal razão pela qual as variações e mudanças da qualidade da democracia ao longo do tempo são importantes ${ }^{172}$ tanto como resultado quanto como facilitador de lutas pelo desenvolvimento humano e direitos humanos ${ }^{173}$.

\section{Quarta digressão sobre a avaliação da Qualidade da Democracia}

Da seção precedente é possível concluir que uma avaliação da qualidade da democracia não deveria ser indiferente a respeito do nível alcançado, ou não, em termos de certos aspectos básicos do desenvolvimento humano e dos direitos humanos, nem acerca de quantos são (e que características sociais têm) aqueles que estão privados desses direitos e capacidades básicas. Como é evidente, severas privações nessas dimensões significam que, exceto para indivíduos excepcionais, sua condição de agentes políticos está profundamente avariada; na medida em que a democracia entranha a cidadania política, incluindo os direitos participativos, ela inclui a expectativa de que pelo menos todos estejam acima de um piso mínimo de capacidades humanas e direitos humanos básicos que lhes permitam, se assim o quiserem, exercer sua cidadania política ${ }^{174}$.

Incluo aqui alguns aspectos de desenvolvimento humano e de direitos humanos relevantes, sem pretender que eles constituam uma lista completa.

\section{XIV.1. Em termos - basicamente - de desenvolvimento humano}

XIV.1.1 Quantidade, porcentagem, posição social, gênero, idade e localização geográfica de indigentes e/ou indivíduos que não atingiram níveis mínimos de alimentação, habitação, abrigo e água potável.

\footnotetext{
${ }^{172}$ Não tenho tido espaço para me ocupar aqui do importante e complexo problema do pluralismo cultural. Permitam-me apenas observar que, em nossos dias, as democracias têm enfrentado essa questão mais decentemente do que os regimes autoritários e as democracias oligárquicas. Por certo, há muito por fazer; a intersecção das regras legais (inclusive democráticas) e dos sistemas legais comunitários (especialmente os de comunidades indígenas) não evita a emergência de problemas sumamente complexos e, às vezes, conflitivos. Considero, no entanto, que a legalidade democrática deveria permitir enfrentar esses problemas do modo decente e respeitoso da diversidade cultural.

${ }^{173}$ Sobre este tema me remeto novamente aos comentários de Méndez, quem utilmente discute vários temas problemáticos que deveriam se resolvidos antes que estas convergências frutifiquem.

${ }^{174}$ Lembremos que esta consideração foi feita tão precocemente como em Atenas; e que a mesma impulsionou o desenvolvimento do estado de bem-estar nos países pioneiros.
} 
XIV.1.2 Idem de indivíduos afetados pela falta de acesso a serviços de saúde, por doenças previníveis e deficiências herdadas ou adquiridas, causadas por qualquer das privações enumeradas nesses itens.

XIV.3. Idem de analfabetos absolutos ou funcionais, e de taxas de matricula e deserção nos diversos níveis educativos.

XIV.4. Idem de indivíduos desempregados ou trabalhando em setores da economia nos quais não são reconhecidos seus direitos civis ou trabalhistas básicos.

\section{XIV.2. Em termos - basicamente - de direitos humanos}

XIV.2.1. Número, posição social, gênero, idade e localização geográfica de indivíduos que são ou tenham sido vítimas de violência física.

XIV.2.2. Idem de indivíduos afetados aos que se lhes nega de fato ou de direito as garantias de equidade e justiça, especialmente, mas não exclusivamente, nos tribunais.

XIV.2.3. Número e localização geográfica de diferentes tipos de delitos especialmente sexuais, homicídios e roubos à mão armada.

XIV.2.4. Se os estrangeiros gozam dos mesmos direitos civis e sociais que os cidadãos; se ao menos em nível local podem participar politicamente e se são tratados pelas instituições do estado e pelos cidadãos com a consideração e respeito devidos.

Como se pode ver, a lista precedente é nitidamente incompleta, mas é útil para sugerir alguns critérios práticos relevantes. Ainda que não seja tarefa menor reunir (ou, quando disponíveis, organizar) o tipo de dados implicado nas digressões precedentes, os mesmos correspondem naturalmente ao campo de investigação da qualidade da democracia. Em contrapartida, os dados implicados pelos itens arrolados na presente digressão constituem o principal campo empírico das instituições que trabalham com desenvolvimento humano e direitos humanos. Especialmente se essas instituições estão convencidas das conexões proximas que existem entre seus temas específicos e a democracia, deveriam compartilhar seus dados com os que tentam avaliar a qualidade da democracia. Esses, por sua vez, deveriam certamente compartilhar seus próprios dados com essas instituições.

\section{Algumas precisões sobre a Qualidade da Democracia}

Neste ponto, após a última digressão, resumo minhas opiniões sobre a conceptualização da qualidade da democracia. Aludo com esta expressão à existência de diferentes graus de democracia ou, equivalentemente, de democraticidade. Refiro-me com isto aos itens (ou, como propõe a Auditoria, os padrões) que propus nas digressões anteriores. 
Os mesmos devem ser considerados vetores que mapeiam diversas dimensões ou aspectos da democraticidade ${ }^{175}$. A distância observada em relação ao nível estabelecido pelo respectivo padrão, ou eventualmente, em relação a um piso que indicaria a ausência do fator ou dimensão em questão, estabeleceria (ou permitiria um juízo fundamentado sobre) a democraticidade relativa dessa dimensão. $\mathrm{O}$ resultado geral seria uma série de vetores ${ }^{176}$ - por certo, alguns deles melhor mensurados do que outros - de democraticidade relativa ${ }^{177}$.

Como a Auditoria tem feito na Costa Rica, e com a experiência derivada da mesma, avaliações semelhantes em outros países (ou, no caso, regiões ou cidades) poderiam proporcionar um novo e útil conhecimento sobre o funcionamento - os avanços e as falhas de uma democracia dada. Ademais, com bons procedimentos metodológicos, parte importante desses dados poderia ser comparável envolvendo diferentes casos ou períodos.

Aqui explicito uma preferência pessoal: quanto mais democraticidade, melhor. Isso não implica ignorar que, como já mencionei, existem contraposições (trade-offs) que afetam a conquista de certos direitos ou capacidades, nem que quase nunca as coisas boas vêm todas juntas. Porém sigo acreditando que in dubio pro democracia; isto é, as contraposições que gerem erosão em alguma dimensão democrática deveriam ser cuidadosamente justificadas. Estas justificativas, ademais, deveriam poder ser discutidas publicamente e a decisão de aceitar essa contraposição deveria ser feita por instituições autorizadas legalmente que, além disso, procedem de acordo com regras democráticas ${ }^{178}$ (ou, como nos exemplos que apresentei acima em relação à forma de tomar certas decisões em matéria de tipo de mudança ou de segurança nacional, por instituições que tenham sido apropriadamente autorizadas para isso e cuja autoridade possa ser desafiada por meios democráticos).

Devo agora relativizar minha afirmação de que in dubio pro democracia. Creio que este é um critério geral válido. No entanto, o mesmo não exclui a discussão teórica e, por

\footnotetext{
${ }^{175}$ Este procedimento é equivalente à "precisão" (precising) de uma definição analisada por Collier e Levitsky (1997). Sobre os temas discutidos na presente seção, ver os comentários de Alcántara Sáez, Coppedge, Mazzuca e Munck.

${ }^{176}$ Ou o "mapa" de picos, vales, poços e outras imagens geográficas que a Auditoria (2001, p. 46 e passim) tem desenhado, imaginativamente, com seus dados.

${ }^{177}$ Portanto, apesar de alguns mal-entendidos que meu texto original aparentemente provocou, coincido com a orientação geral dos comentários metodológicos de Alcántara Sáez, Mazzuca, Munck e Coppedge, por exemplo, quando o último argumenta que para a realização de uma auditoria "No necesitamos formular ningún derecho absoluto o lista de derechos absolutos; sólo necesitamos saber cuánto de cada bien corresponde a qué grado de democracia" (itálico no original). Por outro lado, uma importante questão metodológica que fica pendente é se seria possível ou conveniente reduzir estes vetores a algum tipo de escala ou índice; sobre este tema ver os comentários de Munck e as obras ali citadas.

${ }^{178}$ Por "regras democráticas" entendo, no presente contexto, que as instituições públicas respectivas procedem de maneira correspondente aos respectivos itens nos excursos precedentes.
} 
certo, eminentemente política a respeito de duas questões: "Quanta democracia?" e "Democracia onde?" avançar homogeneamente em todos os vetores de democratização, enquanto no outro extremo um democrata conservador preferiria níveis baixos em vários desses vetores ${ }^{180}$. A preferência que expressei não pretende excluir esta questão, que está no coração mesmo daquilo a que a política democrática (e, de fato, a política em general) se refere. Para quais esferas, além do regime, deveriam ser estendidos os procedimentos democráticos de tomada de decisões e o princípio e os direitos da cidadania? Quais custos, em termos de possíveis contraposições com outras metas, estamos dispostos a pagar por avanços na democratização? Os procedimentos democráticos e os princípios da cidadania deveriam ser estendidos ao - digamos funcionamento interno dos partidos políticos, aos sindicatos e às associações empresariais, mas não, por exemplo, às empresas, às universidades, às organizações internacionais e às famílias? Podem existir critérios razoavelmente coerentes e amplamente aceitos que autorizem a estabelecer parâmetros sobre aonde aplicar e aonde não aplicar esses mecanismos e princípios? E, mais complicado ainda: quem, e por meio de qual processo de tomada de decisão (democrático ou outro) deveria decidir este tipo de questão?

Um tratamento satisfatório destes temas requer teorias da democracia que ainda são inexistentes ${ }^{181}$. Ademais, essas teorias deveriam aceitar que nestas matérias estamos tratando com o mais profundo e definitivamente indecidível. Uma concepção de democracia que pretenda ser coerente deve estar fundada, como vimos, numa visão das pessoas enquanto agentes e no caráter universalista da aposta democrática do regime.

A indecidibilidade teórica dos direitos políticos, tanto considerados em si mesmos quanto (ainda mais) se reconhecemos também os direitos civis e sociais como relevantes para a democracia, possibilitam à democracia sua peculiar dinâmica e seu caráter historicamente aberto. Como consequência, não só os autoritários, mas também os democratas sinceros de diversas correntes debaterão sempre onde, como, por quem e por que deveriam ser colocados os limites da democracia e com ela, da própria política ${ }^{182}$. Esses debates não serão decididos

\footnotetext{
${ }^{179}$ Tal como se pergunta Bobbio (1984).

${ }^{180}$ Por exemplo, argumentando que a democracia se refere exclusivamente ao regime e que, inclusive dentro dele, uma participação ampliada poderia pôr em perigo a conquista de outros valores, tais como a estabilidade política, a eficácia da política econômica ou outros.

${ }^{181}$ Ou simplesmente abster-se de discutir estes problemas como relevantes para uma teoria da política e/ou da democracia. Ver por exemplo o grande cuidado com o qual, em seus vários ajustes na sua "teoria da justiça", Rawls tem argumentado que a mesma não se aplica a instituições sociais como as que tenho enumerado; para uma formulação recente ver Ralws (2001).

${ }^{182}$ Penso advertir que, não de modo casual e mesmo avançando por um caminho diferente, chegamos a uma conclusão análoga à da proposição n. 25.
} 
somente por razões normativas e analíticas; eles estarão contundantemente influenciados por considerações ideológicas, práticas e de prudência - fundamentalmente políticas - a respeito de, entre outros fatores, os recursos e desigualdades num dado país, sua configuração de classes e setores sociais, as alianças internas existentes e possíveis e o contexto internacional.

Obviamente, estas questões estão fora do alcance do presente texto. No entanto, posso fazer dois comentários. Um é que uma avaliação da qualidade de uma democracia deveria ser útil para todos, incluindo aqueles que pensam que os avanços em algum de seus vetores são indesejáveis: uma avaliação desse tipo gera informação pública para o uso de cidadãos(ãs) que podem legitimamente estar em desacordo sobre quanta democracia desejam e onde a desejam. O segundo comentário é que, como pode ter sido observado na terceira digressão (bem como nos padrões da Auditoria), não considero evidente que os mecanismos democráticos sejam adequados para todas as instituições sociais. Contudo, no presente texto a discussão sobre a condição de agentes que têm todos os seres humanos em todas as esferas sociais - não só em termos de regime - implica que, nas instituições sociais não-democráticas, os direitos civis e trabalhistas de seus membros sejam respeitados: já que os agentes são sempre agentes em todas as partes, a ausência de processos democráticos numa determinada situação social não justifica o despotismo nem a arbitrariedade.

Agrego, agora, alguns comentários sobre os vários níveis apontados por minhas sugestões sobre os itens mediante os quais seria possível avaliar a qualidade da democracia. Parto da consideração de que o regime, bem como as atitudes e opiniões dos cidadãos a respeito da democracia e de alguns aspectos gerais da política (primeira digressão), não são problemáticos enquanto tópicos a ser avaliados ${ }^{183}$. Por outro lado, a discussão sobre a democraticidade das instituições do estado e do sistema legal (segunda digressão) conduziunos para além das teorias centradas no regime. No entanto, espero ter mostrado que esses são aspectos sumamente importantes da democracia; consequentemente, e apesar das previsíveis dificuldades para a obtenção de dados ${ }^{184}$, não deveriam ser poupados esforços para também medir este nível. Ademais, com base no argumento de que certas características do contexto social são (ao menos) condição necessária da democracia, e de que as variações nessas características provavelmente têm forte relação com a qualidade da mesma, incluí na terceira digressão alguns itens destinados a avaliar algumas dessas características. Finalmente, a conexão crucial que creio ter mostrado que existe entre a democracia, o desenvolvimento humano e os direitos humanos me conduziu à lista proposta na quarta digressão.

\footnotetext{
${ }^{183}$ Apesar de que, como já observei, alguns podem não estar de acordo sobre a desejabilidade do avanço na democratização de alguns destes itens.

${ }^{184}$ Por certo, a Auditoria é um excelente exemplo de como, com uma boa dose de imaginação e esforço, algumas dessas dificuldades podem ser superadas.
} 
Com estes passos fui muito além das concepções usuais da democracia. No entanto, acredito que minha discussão sobre os diversos aspectos da cidadania e, consequentemente, da agência, justifica a inclusão desses quesitos numa avaliação da qualidade da democracia.

\section{Notas Epistemológicas sobre a avaliação da Qualidade da Democracia}

No "Decálogo" de avaliação da democracia que preparei para o projeto da Auditoria de Costa Rica ${ }^{185}$, sustentei o argumento de que um procedimento apropriado deveria combinar portas de entrada "internas" e "externas". Entendo assim que uma combinação de especialistas e de cidadãos politicamente informados estabelecem as características básicas que definem a democracia, bem como as aspirações, ou padrões, que podem ser propostos a fim de avaliar sua qualidade de uma maneira razoável ${ }^{186}$. Por outro lado, uma avaliação deste tipo não pode deixar de convidar os(as) próprios(as) cidadãos(ãs) a manifestar suas opiniões, tanto em termo dos déficits e das conquistas de sua democracia como quanto às aspirações que têm em relação a ela.

A razão desta dupla via de entrada é óbvia. Por um lado, uma perspectiva puramente externa corre o risco de ser demasiadamente abstrata, técnica, e/ou distante no que diz respeito ao modo pelo qual a cidadania avalia sua própria democracia. Por outro lado, uma aproximação puramente interna, especialmente em países onde a democracia tem sérias deficiências, corre o risco de coletar opiniões que podem estar pobremente informadas ou ser a expressão das "preferências adaptativas" de indivíduos severamente carentes ${ }^{187}$. É por isso que a Auditoria sustenta, com razão, que não se trata de um exercício teórico/acadêmico orientado a formular, testar e revisar proposições teóricas, mas sim de uma avaliação - uma auditoria propriamente dita. Este exercício, entretanto, não é toscamente empirista; encontrase teoricamente sustentado por conceitos que discutem o que é a democracia e suas diferentes dimensões. Este momento teórico - externo - leva a um momento interno, que consiste em

\footnotetext{
${ }^{185}$ Ver anexo 2 ao final desse capítulo.

${ }^{186}$ Ao fazer estas recomendações e as que as seguem, segui de perto os critérios usados pela Auditoria (2001, p. 30-31 e passim), incluindo seu conjunto de padrões tanto para o Umbral Mínimo de Garantías Democráticas como para o Umbral Superior de Calidad Democrática. Para outros e valiosos detalhes, remeto a esses dois volumes, bem como ao texto de Vargas Cullell et. al..

${ }^{187}$ Sobre as preferências adaptativas (ou endógenas), ver Elster (1985). Sen tem reforçado este tema em vários trabalhos como parte de sua crítica a, entre outros, o utilitarismo e a ideia de Rawls a respeito dos "bens primários". Sen adverte, com razão, contra a tendência a considerar como critérios de avaliação as muito modestas preferências que podem ser expressas por indivíduos severamente desprovidos. Para citar este autor, "el perdedor que abandona la esperanza pierde [também] el coraje de desear un mejor pasar y aprende a encontrar placer en pequeñas dádivas [...] Las privaciones aparecen atenuadas y enmudecidas en la métrica de las utilidades"; Sen (1984a, p. 512), ver também Sen (1985b e 1992).
} 
observar, com o maior detalhe e cuidado possíveis, como os(as) cidadãos(ãs) percebem a democracia que existe no seu país. Ao mesmo tempo, num terceiro estágio, estas perspectivas cidadãs retornam à Auditoria e lhes são atribuídas espaços em quadriculas conceituais que estão, como já observei, teoricamente guiadas. Depois dessa etapa de incorporação e localização conceitual da informação "interna", a mesma é analisada em termos de sua distância em relação aos padrões (ou os pisos mínimos, se for o caso) que a teoria e as observações comparativas sugerem, inicialmente, como características factíveis e desejáveis de uma democracia de boa qualidade ${ }^{188}$.

Esses complicados, mas indispensáveis movimentos (em direção a e a partir das perspectivas interna e externa e em direção aos e a partir dos dados empíricos e conceitos teóricos) impedem, como foi observado, que a avaliação possa ser considerado per $s e^{189}$ uma empresa e um produto teórico/acadêmico. Ele é, como os autores da Auditoria corretamente indicam, um instrumento com o qual os(as) próprios(as) cidadãos(ãs) avaliam a sua democracia $^{190}$. Nesse sentido importante, a Auditoria é uma tentativa de enriquecer a esfera pública, particularmente enquanto contribuição para a expansão da restringida agenda pública que, como já comentei, acomete muitos dos nossos países. Por esta razão é crucial que, depois dos passos que descrevi, os principais resultados da Auditoria retornem à cidadania por meios que sejam amplamente acessíveis e facilmente compreensíveis ${ }^{191}$.

\section{Algumas Conclusões}

Sob um regime democrático, os direitos à participação política, bem como os de expressão, associação, movimento e outros semelhantes, devem ser respeitados em virtude da própria definição desse regime - se não o são, esse regime deixa de ser democrático. Esses são direitos que, pelo menos em termos de sua validade formal, não são problemáticos. Por sua vez, o núcleo histórico dos direitos humanos (à vida, à integridade física, à proteção e reparação de violências de diferentes tipos, e semelhantes) tem sido consagrado pelos sistemas legais de praticamente todos os países no mundo atual. Nos dias atuais poucos aspirariam, ao

\footnotetext{
${ }^{188}$ Devo apontar que esta é minha própria reconstrução da lógica dos passos metodológicos adotados pela Auditoria.

${ }^{189}$ Digo per se, porque os dados, a experimentação metodológica e a revisão das categorias conceituais induzidas pela incorporação de perspectivas internas são uma rica mina para estimular a investigação e avanços teórico/académicos.

${ }^{190}$ Ou, como digo no "Decálogo", um jogo de espelhos para este fim.

${ }^{191}$ O esforço que os líderes da Auditoria de Costa Rica estão fazendo nesta direção é um dos muitos aspectos elogiáveis desse projeto.
} 
menos publicamente, que esses não fossem direitos válidos e exigíveis ${ }^{192}$, ainda que tenhamos visto que numa parcela da América Latina estejamos distantes da sua implementação plena. O problema mais complexo se refere ao desenvolvimento humano e, por conseguinte, aos direitos sociais, especialmente em relação àqueles que "morrem tão lentamente que ninguém chama isso de assassinato"193. Diversos teóricos contemporâneos sustentam que esses são fatos hediondos que podem abrir espaço para reclamos morais, porém eles objetam que as conseguintes necessidades gerem direitos positivos subjetivos, isto é, que levem a ações contra o estado. Alguns desses argumentos diretamente negam a validade dessa pretensão; outros destacam a impossibilidade de atingir um acordo generalizado sobre qual seria um conjunto aceitável desses direitos; outros sustentam a impossibilidade fática de satisfazer as necessidades correspondentes, especialmente, mas não exclusivamente nos países pobres, e outros, por fim, apontam que os custos de aumentar o ônus de tributos dos ricos para satisfazer essas necessidades superariam, inclusive para os mais pobres, os ganhos que disso obteriam.

Isoladamente ou em conjunto, esses argumentos têm dominado a agenda pública durante as duas últimas décadas, tanto nos países ricos quanto nos pobres. No entanto, considerando esse tema desde o ângulo da agência e das capacidades e direitos mínimos que podem habilitá-la, considero difícil negar que a satisfação daquelas necessidades é um direito positivo. Isso nos leva, uma vez mais, à questão da democracia e sua qualidade. Vimos que a questão de decidir quais direitos políticos, quais capacidades para o desenvolvimento humano e quais direitos humanos - e em que sequências e a que custos - deveriam ser implementados, tem sido e continuará sendo a própria matéria das lutas democráticas. Esses são processos políticos que às vezes conduzem as decisões tomadas pelo estado. A história mostra em abundância que nunca foi possível estabelecer - muito menos implementar - de forma simultânea, um "pacote completo" dessas capacidades e direitos. Isso sugere, por um lado, que é injusto pedir uma especificação a priori de um conjunto mínimo suficiente desses direitos e/ou capacidades e, pelo outro, que é igualmente injusto descartar demandas e decisões porque elas não implicam reclamar o alcance simultâneo desse pacote completo. A história é testemunha também que os recursos necessários para conquistar alguns desses direitos e capacidades foram disputados e redefinidos ao longo dos conflitivos e problemáticos processos que resumi nas seções anteriores ${ }^{194}$. Além disso, as sequências de aquisição desses

\footnotetext{
${ }^{192}$ Apesar disso, de maneira perturbadora, diversos estudos e relatórios jornalísticos mostram na maioria dos países de América Latina um apoio bastante amplo à detenção arbitrária, à tortura e ainda ao linchamento de supostos criminosos. Ademais, políticos demagógicos e alguns meios de comunicação de massa estimulam estes sentimentos e o medo à violência social que está na sua base.

${ }^{193}$ Coleridge, citado em Shue (1996, p. 58).

${ }^{194}$ Tem produzido valiosos trabalhos sobre esta questão e outros temas próximos. Ver especialmente Tilly (1998b; 1999b; 1999c); com apropriadas referências a América Latina, ver Huber et. al. (1997; 1999).
} 
direitos e capacidades, bem como seu conteúdo e alcance, têm variado inclusive entre os países pioneiros ${ }^{195}$. Nesses casos, a política democrática, sob diferentes circunstâncias e alianças políticas, levou a priorizar temporariamente certas necessidades sobre outras certamente não menos básicas. As lutas subsequentes não se paralisaram pela suposta injustiça de atender só algumas necessidades, ou por predições de que atribuir os recursos necessários provocariam consequências catastróficas. Por sua vez, como já observei, os progressos na conquista de alguns desses direitos permitiram lutas posteriores por outros. Essas são as formas, às vezes frustrantes e raramente lineares, por meio das quais a política democrática trabalha - mas somente quando trabalha bem, melhorando nesse processo a sua qualidade.

Guilhermo O'Donnell foi professor da Universidade de Notre Dame, Departamento de Governo e Relações Internacionais, e membro do Instituto Kellogg de Estudos Internacionais.

\section{Referências}

ACKERMAN, B. Social Justice in the Liberal State. New Haven: Yale University Press, 1980.

ANDERSON, P. Lineages of the Absolutist State. Londres: NLB [Ed. cast.: El Estado Absolutista. México DF: Siglo Veintiuno, 1987, $9^{\circ}$ edición], 1974.

ARISTOTLE. The Politics. Oxford: Ed. Ernest Baker, Oxford University Press. [Ed.cast.: La Política, Barcelona, Emegé, 1975, 5ºdición], 1968.

BARTELL C.S.C., E.; O'DONELl, A. (eds.). The Child in Latin America: Health, Development and Rights. Notre Dame: University of Notre Dame Press, 2000.

BERLIN, I. Four Essays on Liberty. Oxford: Oxford University Press [Ed. cast.: Cuatro ensayos sobre la libertad, Madrid: Alianza Editorial, 1988], 1969.

BERGER, P.; LUCKMANN, T. The Social Construction of Reality. A Treatise in the Sociology of Knowledge. New York: Doubleday [Ed cast.: La construcción social de la realidad, Buenos Aires: Amorrortu, 1972], 1966.

\footnotetext{
${ }^{195} \mathrm{Um}$ exemplo relevante consiste das importantes diferenças que o estado de bem-estar apresenta nesses países.
} 
BERMAN, H. J. Law and Revolution: The Formation of the Western Legal Tradiition. Cambridge: Harvard University Press, 1993.

BOBBIO, N. Il Futuro Della Democrazia. Una Difesa Delle Regole del Gioco. Torino: Einaudi [Ed cast.: El futuro de la democracia, Barcelona: Plaza y Janés, 1985], 1984.

. Democracy and Dictatorship. The Nature and Limits of State Power. Minneapolis: University of Minnesota Press, 1989.

CENTRO DE ESTUDIOS LEGALES Y SOCIALES (CELS). La inseguridad Policial. Violencia de las Fuerzas de Seguridad en la Argentina. Buenos Aires: Eudeba, 1998.

CALVO, E.; ABAL MEDINA (H), J. M. (eds.). El Federalismo Electoral Argentino. Sobrerepresentación, Reforma Política y Gobierno Dividido en la Argentina. Buenos Aires: INAP/Eudeba, 2001.

COLLIER, D.; LEVITSKY, S. Democracy with Adjectives: Conceptual Innovation in Comparative Research, World Politics, 49, n. 3, p. 430-451, 1997.

DAHL, R. Democracy and Its Critics. New Haven: Yale University Press [Ed cast.: La democracia y sus críticos, Barcelona: Paidós, 1993], 1989.

. On Democracy. New Haven: Yale University Press [Ed.cast.: La democracia. Una guía para los ciudadanos, Buenos Aires: Taurus, 1999], 1998.

DALTON, R. Political Support in Advanced industrial Democracies. In: NORRIS, Pippa (ed.). Critical Citizens. Global Support for Democratic Governance. Oxford: Oxford University Press, 1999. p. 56-77.

DASGUPTA, P. An Inquiry into Well-Being and Destitution. Oxford: Clarendon Press, 1993.

DELlASOPPA, E.; BERCOVICH, A.; ARRIAGA, E. Violência, Direitos Civis e Demografía no Brasil na Década de 80, Revista Brasileira de Ciências Sociais, ANPOCS, 14, n. 39, p. 155-176, 1999.

DWORKIN, R. Taking Rights Seriously. Cambridge USA: Harvard University Press, 1978. 
Law's Empire. Cambridge USA: Harvard University Press, 1986.

ELKLIT, J.; SVENSSON, P. What Makes Elections Free and Fair? Journal of Democracy, Washington, v. 8, n. 3, p. 32-46, 1997.

ELSTER, J. Sour Grapes. Studies in the Subversion of Rationality. Cambridge / Paris: Cambridge University Press - Editions de la Maison des Sciences de l'Homme [Ed cast.: Uvas amargas, Barcelona, Ediciones 62, 1988], 1985.

FÁBRE, C. Constitutionalising Social Rights. The Journal of Political Philosophy, Oxford, v. 6, n. 3, p. 263-284, 1998.

FRANCK, T. Are Human Rights Universal? Foreign Affairs, v. 80, n. 1, p. 191-204, 2001.

FROHLICH, N.; OPPENHEIMER, J. Choosing Justice. An Experimental Approach to Ethical Theory. Berkeley: University of California Press, 1992.

FULLER, L. The Morality of Law. New Haven: Yale University Press, 1964.

GARRETÓN, M. A. Reconstruir la Política. Transición y Consolidación Democrática en Chile. Santiago: Editorial Andante, 1987.

GARZÓN VALDÉS, E. Derecho, Etica y Politica. Madrid: Centro de Estudios Constitucionales, 1993.

. Prólogo a Rodolfo Vázquez. Liberalismo, Estado de Derecho y Minorías. México DF: Paidós, 1993. p. 11-26.

GEWIRTH, A. Reason and Morality. Chicago: The University of Chicago Press, 1978.

GOLDSTEIN, R. Political Repression in Europe. London: Croom Helm, 1983.

GRAY, J. Two Faces of Liberalism. New York: The Free Press [Ed.cast.: La dos caras del liberalismo, Barcelona: Paidos, 2001], 2000. 
HABERMAS, J. Law as Medium and Law as Institution. In Gunther Teubner (ed.). Dilemmas of Law in the Welfare State. New York / Berlin: de Gruyter, 1988. p. 204-220.

. Between Facts and Norms. Cambridge MA: The MIT Press, 1996.

. Introduction. Ratio Juris, Malden, v. 12, n. 4, p. 329-335, 1999.

HAMBURGER, P. A. The Development of the Nineteenth-Century Consensus Theory of Contract. Law and History Review, Cambridge, v. 7, n. 2, p. 241-329, 1989.

HANSEN, M. H. The Athenian Democracy in the Age of Demosthenes. Oxford: Oxford University Press, 1991.

HARSANYI, J. Can the Maximin Principle Serve as the Basis of Morality? A Critique of lohn Rawls Theory. American Political Science Review, Washington, n. 69, p. 690-705, 1975.

HART, H.L.A. The Concept of Law. Oxford: Claredon Press, 1961.

HELD, D. Derecho de los Estados, Derechos de los Pueblos: Tres Modelos de Soberania. PostData, Buenos Aires, n. 8, p. 11-62, 2002.

HIRSCHMAN, A. O. The Rhetoric of Reaction. Cambridge: The Belknap Press of Harvard University Press [Ed cast.: Retóricas de la intransigencia, México DF: Fondo de Cultura Económica, 1991; reimpr., 1994], 1991.

HOLMES, S. AND SUNSTEIN, C. The Cost of Rights. Why Liberty Depends on Taxes. New York: W.W. Norton, 1999.

HSIEH, C. C.; PUGH, M. D. Poverty, lncome inequality, and Violent Crime: A MetaAnalysis of Recent Aggregate Data Studies. Criminal Justice Review, Atlanta, v. 18, n. 2, p. 182-202, 1993.

HUBER, E.; RUESCHEMEYER, D. y STEPHENS, J. D. The Paradoxes of Contemporary Democracy: Formal, Participatory, and Social Democracy. Comparative Politics, New York, v. 299, n.3, p. 323-342, 1997. 
HUBER, E.; STEPHENS, J. D. The Bourgeoisie and Democracy: Historical and Comparative Perspectives. Social Research, New York, v. 66, n.3, 1999.

HUNTINGTON, S. P. The Third Wave. Democratization in the Late Twentieth Century. Norman / London: University of Oklahoma Press [Eel cast.: La Tercera Ola. La Democratización a finales del siglo XX, Barcelona: Paidós, 1994], 1991.

IAZZETTA, O. Estado y Democracia: Una Revisión sobre un Vínculo Necesario, multicopiado. Rosario: Universidad Nacional de Rosário, 2002.

JONES, P. Rights. New York: St.Martin’s Press, 1994.

KELSEN, H. Pure Theory of Law. Berkeley: University of California Press [Ed. cast.: Teoría Pura del Derecho, Buenos Aires: Eudeba, 1986, 23 ed.], 1967.

LACEY, N. Responsibility and Modernity in Criminal Law. The Journal of Political Philosophy, Oxford, v. 9, n. 3, p. 249-276, 2001.

LANE, R. Procedural Goods in a Democracy: How One is Treated Versus What One Gets. Social Justice Research, Laraime, v. 2, n. 3, p. 177-192, 1988.

LECHNER, N. Desafíos de un Desarrollo Humano: Individualizacion y Capital Social. Instituciones y Desarrollo, Barceona, n. 7, p. 7-34, 2000.

LINZ, J. J.; STEPAN, A. Problems of Democratic Transition and Consolidation. Southern Europe, South Arnerica, and Post-Communist Europe. Baltimore: The John Hopkins University Press, 1996.

MALLOY, J. Politica Económica e o Problema de Governabilidade Democratica nos Andes Centrais. In: L. Sola, (org.). Estado, Mercado e Democracia: Politica e Economia Comparada. São Paulo: Paz e Terra, 1991.

MARGALIT, A. The Decent Society. Cambridge USA: Harvard University Press [Ed. cast.: La sociedad decente, Barcelona: Paidós, 1997], 1996.

MARSHALL, T.H. Citizenship and Social Class. In: MARSHALL, T.H., ed., Class, Citizenship and Social Development. New York/Garden City: Doubleday [1949], 1965. 
MÉNDEZ, J.E., O’DONNELL, G; PINHEIRO, P.S. (eds.). La (In)Efectividad de la Ley y la Exclusión en América Latina. Buenos Aires: Paidós, 2002.

MILL, J. S. On Liberty. Glasgow: Collins/Fontana [Ed. cast.: Sobre la libertad, Buenos Aires: Aguilar, 1954], 1962.

MOUFFE, C. Democracy, Power, and the Politica. In: S. Benhabib (ed.), Democracy and Difference. Contesting the Boundaries of the Political. Princeton: Princeton University Press, 1996. p. 245-256.

. The Democratic Paradox. London: Verso, 2000.

NEWEY, G. Value-Pluralism in Contemporary Liberalism. Dialogue, p. 439-552, 1998.

NOZICK, R. Anarchy, State, and Utopia. New York: Basic Books [Ed.cast.: Anarquía, Estado y Utopía, Mexico DF: Fondo de Cultura Económica, 1988], 1974.

NUSSBAUM, M. Capabilities and Human Rigts. Fordham Law Review, New York, v. 66, n. 2, p. 273-300, 1997.

NOZICK, R. Aristotle, Politics, and Human Capabilities: A Response to Antony, Arneson, Charlesworth, and Mulgan. Ethics, Georgetown, v. 111, p. 102-140, 2000a.

. Women and Human Development. The Capabilities Approach. Cambridge UK: Cambridge University Press, 2000 b.

O’DONNELL, G. Apuntes para una Teoria del Estado. Docurnentos CEDES/CLACSO, 9 (Buenos Aires, 1978), republicado en O. Oszlak (org.). Teoría de la Burocracia Estatal. Enfoques Criticos. Buenos Aires: Paidós, 1984.

. Acerca del Estado, la Democratizacion y Algunos Problemas Conceptuales. Una Perspectiva Latinoamericana con Referencias a Paises Poscomunistas. Desarrollo Económico, Buenos Aires, v. 33, n. 130, p.163-184, 1993.

. Otra institucionalizacion. Agora, Buenos Aires, 3, n. 5, p. 5-28, 1996. 
. Contrapuntos: Ensayos Escogidos Sobre Autorilarismo y Democratizacion. Buenos Aires: Paidós, 1997a.

. Ilusiones y Errores Conceptuales. Agora, Buenos Aires, v. 3, n. 6, p. 209-221, $1997 b$.

. Accountability Horizontal. Agora, Buenos Aires, v. 4, n. 8, p. 5-34, 1998.

. Pobreza y desigualdad en América Latina: Algunas Refexiones Políticas. V. E. Tokman; G. O’Donnell (eds.). Pobreza y Desigualdad en América Latina. Temas y Nuevos Desafíos. Buenos Aires: Paidós, 1999. p. 69-93.

. Teoría Democrática y Política Comparada. Desarrollo Económico, Buenos Aires, v. 39, n. 156, p. 519-570, 2000.

. Accountability Horizontal: La Institucionalizacion Legal de la Desconfianza Política. PostData, Buenos Aires, n. 7, p. 11-34, 2001a.

- Reflections on Contemporary Latin American Democracies. Journal of Latin American Studies, v. 33, n. 3, p. 599-609, 2001 b.

. Acerca del Estado en América Latina. Diez Tesis para Discusión, preparado para el proyecto PNUD-DRALC. Desafios de la Democracia en América Latina. Buenos Aires / Brasília, 2002a. Disponible em: <wwvv.lademocracia.org.>.

Acerca de Varias Accountabilities y sus interrelaciones. E. Peruzzotti y C. Smulovitz, (eds.). Controlando la Política. Ciudadanos y Medios en las Nuevas Democracias Latinoamericanas. Buenos Aires: Temas, 2002b. p. 87-102.

. Desarrollo Humano / Derechos Humanos / Democracia, ponencia presentada en el Taller desarrollado en Heredia, Costa Rica, 1 e 2 de febrero de 2002, sobre la Calidad de la Democracia, auspiciado por el Programa "Estado de la Nacion" y su proyecto "Auditoría Ciudadana de la Calidad de la Democracia", Costa Rica, y por el Programa de las Naciones Unidas para el Desarrollo, División Regional para América Latina y el Caribe (PNUD PNUD - DRALC), 2002c. Disponible en: <www.estadonacion.or.cr>. 
. Las poliarquias y la (in)Enefectividad de la ley en América latina. J. E. Mendéz et. al.. La (In)Efectividad de la Ley y la Exclusión en América Latina. Buenos Aires: Paidós, 2002d. p. 305-336.

O’DONNELL, G.; SCHMITTER, P. C. Transiciones desde un Gobierno Autoritario. Vol. IV. Conclusiones Tentativas sobre las Democracias Inciertas. Barcelona: Paidós, 1ra reimpresión en España), 1994.

OSZLAK, O.; O’DONNELL, G. Estado y Politicas Estatales en América Latina: Hacia una Estrategia de lnvestigacion. O. Oszlak, (ed.). Teoria de la Burocracia Estatal. Enfoques Críticos. Buenos Aires: Paidós, 1984.

PERUZZPTTI, E.; SMUlOVITZ, C. (eds.) Controlando la Politica. Ciudadanos y Medios en las Nuevas Democracias. Buenos Aires: Temas, 2002.

PREUSS, U. The Political Meaning of Constitutionalisrn. In: Richard Bellamy (ed.), Constitutionalism, Democracy, and Sovereignty: American and European Penspectives. Aldershot: Avebury, 1996. p. 11-27.

PROYECTO ESTADO DE LA NACIÓN (en coautoria de Jorge Vargas Cullell, Miguel Gutiérrez Saxe y Evelyn Villarreal Fernández). Auditoria Ciudadana sobre la Calidad de la Democracia, dos volúmenes, San José, Proyecto Estado de la Nacion en Desarrollo Humano Sostenible, 2001.

PRZEWORSKI, A. et al. Democracy and Development. Political Institutions and Well-Being in the World, 1950-1990. Cambridge: Cambridge University Press., 2000.

RAWLS, J. A Theory of Justic. Cambridge USA: Harvard University Press [Ed. cast.: Teoria de la Justicia. México DF: Fonde de Cultura Económica, 1993], 1971.

. Justice as Fairness. A Restatement. Cambridge USA: The Belknap Press of Harvard University Press [Ed cast.: La Justicia como equidad. Una reformulación, Barcelona: Paidós, 2002], 2001.

. The Morality of Freedom. Oxford: Clarendon Press, 1986. 
. Ethics in the Public Domain. Essays in the Morality of Law and Politics. Oxford: Clarendon Press, 1994.

ROSANVAlLON, P. Le Sacre du Citoyen. Histoire de Sufrage Universel en France. Paris: Gallimard [Ed. cast.: La consagración del ciudadano. Historia del sufragio universal en Francia, México DF: Mora, 2002], 1992.

SCHMITTER, P. The Consolidation of Democracy and Representation of Social Groups. American Behavioral Scientist, v. XXXV, n. 4/5, p. 422-449, 1992.

SCHNEEWIND, J.B. The Invention of Autonomy. A History of Modern Moral Philosophy. Cambridge UK: Cambridge University Press, 1998.

SCOTT, J. Weapons of the Weak. Everyday Forms of Peasant Resistance. New Haven: Yale University Press, 1985.

SEN, A. Rights and Capabilities. In: Amartya Sen. Resources, Values and Devlopment. Cambridge, USA: Harvard University Press, 1984a. p. 307-345.

. Goods and People. In: A. Sen. Resources, Values and Devlopment. Cambridge USA: Harvard University Press, $1984 b$.

. Rights as Goals (Austin Lecture). In S. Guest y A. Milne (ed.). Equality and Discriminatipn: Essays in Freedom and Justice. Stuttgart: Franz Steiner Verlag, 1985a.

. Well-being, Agency, and Freedom: The Dewey Lectures 1984. The Journal of Philoshophy, New York, v. 82. n. 4, p. 169-221, 1985 b.

. Inequality Reexamined. Cambridge / Massachusetts: Harvard University Press, 1992.

. Democracy as a Universal Value. Journal of Democracy, Washington, v. 10, n. 3, p. 3-17, 1999a.

. Development as Freedon. New York: Alfred A. Knopf [Ed. Cast.: Desarrollo y Libertad, Buenos Aires: Planeta], 1999b. 
. A Decade of Human Development. Journal of Human Development, Berkeley, v. 1, n. 1, p. 17-24, 2000a.

. East and West: The Reach of Reason. New York Review of Books, New York, v. 47, n. 12 , p. $33-38,2000$ b.

SHUE, H. Basic Rights. Subsistence, Affluence, and U.S. Foreign Policy. Princeton: Princeton University Press, 1996.

SKINNER, Q. The Idea of Negative Liberty: Philosophical and Historical Perspectives. In R. Rorty et. al. (eds.). Philosophy in History. Essays on the Historiography of Philosophy. Cambridge UK: Cambridge University Press, 1984. p.193-211.

SMUlOVITZ, C.; PERUZZOTTI, E. Social Accountability in Latin America. Journal of Democracy, Washington, v, 11, n. 4, p. 147-158, 2000.

SNYDER, R. y SAMUELS, D. Devaluing the Vote: Latin America. Journal of Democracy, Washington, v. 12, n. 1, p. 146-159, 2001.

STEPAN, A. Religion, Democracy, and the 'Twin Tolerations. Journal of Democracy, Washington, v. 11, n. 4, p. 37-57, 2000.

STRASSER, C. La Democracia versus el Poder. Sociedad, n. 8, p. 84-93, 1996.

. Democracia y Desigualdad. Sobre la "Democracia Real" a Fines del Siglo XX. Buenos Aires: CLACSO-ASDI, 1999.

TAYLOR, C. What's Wrong with Negative Liberty. Philosophy and the Human Sciences. Philosophical Papers 2. Cambridge, UK: Cambridge University Press, 1985. p. 211-229.

THE ECONOMIST. Righting Wrongs (August 18), p. 8; 18-20, 2001.

THOMPSON, E. P. Whigs and Hunters. The Origins of the Black Act. New York: Pantheon, 1975.

TILLY, C. War Making and State Making as Organized Crime. In: P. Evans et. al., (eds.), Bringing the State Back In. Cambridge University Press, p. 169-191, 1985. 
. Coerción, Capital and European States. Cambridge: Blackwell [Ed. Cast.: Coerción, Capital y los Estados Europeos. 990-1990, Buenos Aires, Alianza Editorial, 1993], 1990.

. Durable Inequality. Berkeley: The University of California Press [Ed. Cast.: La Desigualdad Persistente, Buenos Aires: Manantial, 2000], 1998a.

. Where do Rights Come From? In: T. Skocpol (ed.). Democracy, Revolution, and Histor., Ithaca: Cornell University Press, p. 55-72, 1998 b.

. Now Where? In G. Steinmetz (ed.). State/Culture. State Formation after the Cultural Rurn. Ithaca: Cornell University Press, 1999. p. 407-420.

TOKMAN, V.E.; O’DONNELL, G. (eds). Pobreza y Desigualdad en América Latina. Temas y Nuevos desafios. Buenos Aires: Paidós, 1999.

TOURAINE, A. Pourrons-nous Vivre Ensemble? Égaux et Différent. Paris: Fayard [Ed. Cast.: ¿ Podremos vivir juntos? Sao Paulo, Fondo de Cultura Económica, 1999], 1997.

TYLER, T. Why People Obey the Law. New Haven: Yale University Press, 1990.

Multiculturalism and the Willingness of Citizens to Defer to Law and Legal Authorities. Law \& Social Inquiry, Chicago, v. 25, n. 4, 2000.

UNITED NATIONS DEVELOPMENT PROGRAM (UNDP). Human Development Report 2000. Human Rights and Human Development. New York: Oxford University Press [Ed. cast.: Informe sobre Desarrollo Humano 2000. Los Derechos Humanos y el Desarrollo Humano, Madrid, Barcelona, México: Ediciones Mundi-Prensa, 2000], 2000a.

UNITED NATIONS DEVELOPMENT PROGRAM (UNDP). Poverty Report 2000. Overcoming Human Poverty. New York: Oxford University Press [Ed. cast.: Informe de PNUD sobre la Pobreza 2000. Superar la Pobreza Humana, Nueva York: Pnud, 2000], 2000b.

VALENZUELA, J.S. Democratic Consolidation in Post-Transitional Settings: Notion, Process, and Facilitating Conditions. In: MAINWARING, S.; O'DONNELL, G.; VALENZUELA, J.S. (eds.). Issues in Democratic Consolidation: The New South American 
Democracies in Comparative Perspective. Notre Dame: University of Notre Dame Press, 1992. p. 57-104.

VAN CAENEGEM, R.C. An Historical Introduction to Western Constitutional Law, Cambridge UK.: Cambridge University Press, 1995.

WEALE, A. Political Theory and Social Policy. New York: St. Martin’s Press, 1983.

WEBER, M. Economy and Societ. Berkeley: University of California Press, [Ed cast.: Economía y Sociedad, México DF: Fondo de Cultura Económica, 1944; reimpr. 1997], 1968. 2 vols.

VÁSQUEZ, R. Liberalismo, Estado de Derecho y Minorías. México DF: Paidós, 2001.

Recebido em 22/01/2013. Aprovado em 23/01/2013. 


\section{ANEXO 1}

Proporção dos entrevistados que estão de acordo com a frase "La democracia es preferible a cualquier otro tipo de gobierno" (se não se indica data, os dados da primeira coluna são de 1995).

\begin{tabular}{llll}
\hline País & $\mathbf{1 9 9 5}$ & $\mathbf{2 0 0 1}$ & Diferença \\
\hline Argentina & 76 & 58 & -18 \\
\hline Bolívia (1996) & 64 & 54 & -10 \\
\hline Brasil & 41 & 30 & -11 \\
Chile & 52 & 45 & -7 \\
\hline Colômbia (1996) & 60 & 36 & -24 \\
\hline Costa Rica (1996) & 80 & 71 & -9 \\
\hline Equador (1996) & 52 & 40 & -12 \\
El Salvador (1996) & 56 & 25 & -31 \\
\hline Guatemala (1996) & 51 & 33 & -18 \\
Honduras (1996) & 42 & 57 & 15 \\
\hline México & 49 & 45 & -4 \\
\hline Nicarágua & 59 & 43 & -16 \\
\hline Panamá & 75 & 34 & -41 \\
\hline Paraguai & 52 & 35 & -17 \\
\hline Peru & 52 & 62 & 10 \\
\hline Uruguai & 80 & 79 & -1 \\
\hline Venezuela & 60 & 57 & -3 \\
\hline
\end{tabular}

Fonte: Latinobarômetro, 1995, 1996 e 2001. 


\section{ANEXO 2}

\section{O decálogo}

\section{O que a auditoria é e não é}

1. A auditoria não é um projeto acadêmico. Não parte de hipóteses para verificar nem de teorias já formuladas. É um projeto descritivo e avaliativo, que se alimenta de contribuições acadêmicas e suscita diversas atividades deste tipo, mas não se confunde com elas.

2. A auditoria é um instrumento de navegação. Provê a governos e diversas lideranças sociais e políticas, informação mais profunda e detalhada que a que eles habitualmente têm a seu alcance, sobre o que a cidadania pensa e aspira sobre a democracia.

3. A auditoria é um jogo de espelhos. Devolve à cidadania a imagem de como ela se vê a si própria e em relação com a democracia (dimensão subjetiva), bem como padrões de avaliação, objetivos desenvolvidos pela equipe de Auditoria. Através desses espelhos, a Auditoria é consistente com a democracia: as duas são de e para a cidadania.

4. A auditoria revigora a sociedade civil e a accountability societal. Os espelhos subjetivos e objetivos facilitam a autoconsciência da sociedade civil, permitindo detectar problemas e aspirações que de fato compartilha e possibilita diversas ações e movimentos de accountability societal. Fomenta com isso a democratização "desde baixo".

5. A auditoria é um instrumento aberto, em permanente reelaboração. Está é outra razão pela qual a Auditoria não é um projeto acadêmico. O acadêmico "fecha", como produto, com a publicação de um livro ou artigo. Por sua vez, um produto fundamental da Auditoria são as respostas que suscita, tanto nas lideranças como na cidadania em geral. Essas respostas redefinem as avaliações e aspirações sobre a democracia recolhidas no Informe da Auditoria. Este caráter aberto da mesma corresponde a própria democracia: é sempre um horizonte aberto, em termos dos valores e aspirações que encarna.

6. A Auditoria é um produto exportável, mas não a chave na mão. A auditoria respeita as características de cada caso nacional. De forma aproximada poderia se pensar em uma estratégia metodológica de três terços de dados. Um seria um núcleo duro comparativo. Compartilhado por todos os outros. Outro recolheria especificações de cada caso. Um terceiro, no "meio" dos anteriores, consistiria de dados que as 
respectivas equipes nacionais orientadas pela equipe coordenadora geral deveriam tentar torná-las comparáveis, mas sem chegar ao ponto de desconhecer ou descuidar especificidades que a respectiva equipe nacional considera importantes.

7. A Auditoria é um instrumento ideologicamente estratégico. Coloca-se em momentos em que temos na América Latina uma coleção de democracias (boa parte delas de baixa qualidade), semidemocracias e alguns regimes autoritários. Isto é expressão de uma tendência democratizante, que implica um enorme progresso em relação a onda autoritária que não faz muito tempo assolou boa parte da Região. Mas os sucessos democráticos são precários e incompletos. A Auditoria é parte dos inúmeros esforços para reforçar o élan e as práticas democráticas na região. Além do mais avalia as lideranças latino-americanas pela sua palavra. Atualmente é conveniente se dizer democrático(a), ainda que seja dito hipocritamente; a Auditoria aceita literalmente essas afirmações e propõe reforçar e viabilizar a vocação democrática declarada.

8. A Auditoria é crível e imparcial, porém a partir de um enviesamento especifico pródemocrático. A Auditória é crível porque tem um formato institucional, tanto nas suas instâncias consultivas quanto técnicas que garante a seriedade, objetividade e imparcialidade partidária de seus trabalhos. Mas a Auditória não é tímida em tornar público seu viés pró-democracia e o aperfeiçoamento de sua qualidade.

9. A Auditória não é somente um processo de aprendizagem institucional. O Programa das Nações Unidas para o desenvolvimento (PNUD) e seus colaboradores começam com objetivos modestos, movimentando-se me terrenos metodologicamente bem abonados e se explicando persistente ou amplamente, são imparciais, sérios e construtivos nos seus objetivos. Logo vão aprendendo no processo e aumentando progressivamente as ambições do mesmo. A experiência do PNUD com o conceito e informes de desenvolvimento humano tem se enriquecido em si mesmo e ampliando suas conexões com outros temas. Isso foi, evidentemente, o produto de um investimento inteligente institucional que soube proceder incrementalmente, sem perder de vista a meta de ir produzindo progressos importantes na definição, conceitualização, metodologia e impacto do desenvolvimento humano.

10. A Auditoria implica um investimento internacionalmente solido de perspectiva que, no entanto, não é nova para o PNUD. Os típicos (e mais influentes) organismos de ajuda internacional financiam projetos (de estabilização econômica, alivio na balança de pagamentos, reforma do estado, etc.) pela contribuição ao crescimento econômico. Por sua vez, considera que em última análise o crescimento por ser alcançado acabará beneficiando o conjunto da população. Seja qual fosse a veracidade de cada caso dessas afirmações, esses projetos começam pelo macro e somente depois de uma série de complexas e hipotéticas mediações chegam ao micro, às condições de vida do 
conjunto da população. Por sua vez, tanto o desenvolvimento humano como a Auditória começam no micro, com a gente e seu interesse e direito de alcançar um nível decente de desenvolvimento humano (o que Amartya Sen denomina de “capacidades" e "funcionamentos") e a vigência efetiva dos direitos ('liberdades' para Amartya Sen) postulados e pressupostos da democracia. Em virtude deste ponto de partida, o desenvolvimento humano e a Auditoria não podem deixar de tornar explícitos os valores que a sustentam e justificam. Esta inocultabilidade pode ter polemicas, por exemplo, quando o desenvolvimento humano se ocupa de temas de gênero em culturas fechadas machistas, ou quando a Auditoria explicita frente aos autoritários seus viés pró-democrático. Porém, por outro lado, a crescente consciência das consequências negativas que pode ter o enfoque economicista e "desde acima" de outras organizações, apesar do tom democrático e aparentemente neutro, desde o ponto de vista valorativo com que se apresentam, as estão expondo a criticas mais contundentes. De qualquer forma, a identificação do PNUD com o desenvolvimento humano tem se comprometido com o caminho dos "de abaixo" e com a explicitação de alguns valores básicos; está é também o caminho que a Auditoria recorre.

Fonte: Guillermo O’Donnell. Lo que la Auditoría es y no es. In: Proyecto Estado de la Nación (Jorge Cullell en coautoría con Miguel Guitiérrez Saxe y Evelyn Villarreal Fernández), Informe de la Auditoría Ciudadana sobre calidad de la democracia en Costa Rica, v. 1 p. 35-36. Recuadro 0.4. 


\section{ANEXO 03}

\section{Lista de Proposições}

1. Os conceitos de desenvolvimento humano e de direitos humanos compartilham uma perspectiva subjacente universalista de ser humano como um agente.

2. Esta perspectiva conduz a pergunta de quais seriam as condições capacidades e/ou direitos básicos que normalmente permitem ao indivíduo funcionar como agente.

3. Um regime democrático inclui eleições que são limpas e institucionalizadas, bem como uma aposta institucionalizada, inclusiva e universalista.

4. Ademais das características observadas na proposição 3, um regime democrático consiste de algumas liberdades "políticas" (limitadamente) universalistas. Essas liberdades devem ser listadas porque são importantes per se e porque são condições necessárias para a existência de eleições limpas e institucionalizadas, e, portanto para a contínua efetividade da aposta democrática.

5. No entanto, em virtude dos limites externos e internos destas liberdades serem indecidíveis, não há um critério valido para esclarecer firmemente um conjunto mínimo suficiente desses direitos que tenha validade teórica e/ou intersubjetiva geral.

6. A aposta democrática e a cidadania política são, respectivamente, as caras coletiva e individual da mesma moeda - o regime democrático - e ambas pressupõe o estado, tanto como uma delimitação territorial como um sistema legal (que além disso deve ser atuado por diversas burocracias que se desempenham em consonância com o mesmo).

7. A cidadania política consiste na designação universalista (embora territorialmente delimitada) dos direitos e liberdades vinculados a uma aposta democrática inclusiva, ou seja, tanto de algumas liberdades circundantes como dos direitos a participação em eleições limpas e institucionalizadas, incluindo votar e ser eleito(a).

8. Um regime democrático (ou democracia política ou poliarquia) pressupõe: a. um estado territorialmente baseado que delimita quem são considerados cidadãos(ãs) políticos(as); e b. Um sistema legal desse mesmo estado que, dentro de seu território, designa a cidadania política sobre essas bases (limitadamente) universalistas.

9. No Noroeste, a concepção do individuo como um agente teve, bastante antes da extensão universalista da cidadania política, um longo processo de elaboração de diversas doutrinas religiosas, éticas e filosóficas. Essa mesma concepção foi cuidadosamente elaborada e progressivamente implementada, ao ritmo da expansão do capitalismo e do estado moderno, como uma doutrina legal que, designando 
direitos subjetivos e um crescente número de indivíduos, lhes foi atribuído, legal e universalmente, condições de agentes

10. Depois de uma longa e complexa trajetória histórica, nos países iniciadores - em geral e não sem interrupções abruptas - ocorreu a extensão bastante ampla de uma (majoritariamente masculina) cidadania civil, baseada na atribuição legal de agência nesta esfera. Esta foi a base, legal e sociológica, de um desenvolvimento superior, a democracia política, centrada na cidadania política. Esta, por sua vez, se baseou numa concepção de agência já desenvolvida nesses países no terreno dos direitos civis.

11. Nos países iniciadores, o tema das opções que tornam realmente possível a agencia foi abordado originariamente como uma questão de direitos civis e, mais tarde, também de direitos sociais. A visão subjacente as resultantes construções legais é, salvo prova em contrário legalmente estipulado, da equidade que se deve a indivíduos construídos como sujeitos capazes de opções livres e responsáveis - ou seja, como agentes.

12. A concepção do ser humano como agente tem consequencias diretas e convergentes sobre as esferas civil, social e política, porque é uma concepção moral, que em vários aspectos tem sido estabelecida legalmente, do ser humano como individuo autônomo, razoável e responsável.

13. A democraticidade é um atributo do estado, não somente de regime.

14. A democracia tem quatro características distintas em relação com outro regime político: 1) eleições limpas e institucionalizadas; 2) uma aposta inclusiva e (limitadamente) universal; 3) um sistema legal que estabelece e respalda -pelo menos - os direitos e liberdades implicados por um regime democrático; e 4) um sistema legal que proíbe que qualquer seja de legibus soluts. As primeiras das características correspondem ao regime; as duas últimas ao estado. Portanto, as teorias sobre a democracia que se limitam ao estudo do regime sub-especificam erradamente seu tema.

15. A efetividade de um sistema legal depende da articulação de suas regras com uma rede de instituições que atuam com propósitos e resultados que são geralmente coerentes, quando existe um regime democrático, com um estado democrático de direito.

16. Na democracia, as instituições do estado têm o dever (correlativo aos direitos da cidadania política e civil) de tratar a todos com equanimidade, consideração e respeito devidos a um agente.

17. Ainda que a tendência a negar esses direitos esteja estruturalmente inscrita em toda relação vertical d poder (especialmente se está burocratizada), a pobreza e a desigualdade agudas tendem a acentuar poderosamente essa tendência. 
18. A efetividade dos direitos da cidadania política requer um contexto social que inclua fontes de informação variadas, não monopolizadas ou censuradas pelo estado. Essa possibilidade, que é um componente de um contexto socialmente diverso e plural, é um bem público respaldado por um sistema legal democrático e pelo adequado desempenho das instituições estatais.

19. Mais amplamente, a existência de um contexto social semelhante, juntamente com a existência de diversas liberdades políticas, na medida em que implicam que múltiplos agentes possam eleger livremente seus funcionamentos, é um aspecto social que reconhece e alimenta a mesma agência que é pressuposta pela democracia.

20. Os direitos até agora examinados (políticos e civis), na medida em que são designados a sujeitos, como agentes, têm uma intrínseca dimensão individual. Porem, à medida que se projetam coletivamente como liberdades que caracterizam - e sustentam - um contexto social diverso e plural, esses mesmos direitos têm uma dimensão não menos intrinsecamente social.

21. Em contraste, com os países iniciadores, na maior parte da América Latina (e, em termos de população, para a grande maioria da população desta região), os direitos políticos foram conseguidos, ou têm sido recuperados recentemente, antes de se completar uma generalização dos direitos civis. Por sua vez, dependendo da trajetória seguida por cada país, alguns direitos sociais foram outorgados antes ou depois dos direitos políticos, em todos os casos esses direitos foram limitados e ultimamente têm sofrido, em muitos países, retrocessos significativos.

22. Nesses países, a penetração e efetividade da legalidade estatal têm sido intermitente e socialmente enviesadas. Ademais, em não poucos países, inclusive em governos democraticamente eleitos, as regiões não cobertas pela legalidade estatal não tem diminuído e, em alguns casos, têm aumentado.

23. Em qualquer circunstância histórica, é inevitável matéria de discussão que direitos, com que intensidade, com que alcance e com que prioridade são sancionados e implementados.

24. Este fato se deve a restrições institucionais e econômicas, mas também à diversidade social que resulta da agência humana e, portanto, às diversas perspectivas, e estilos de vida, ideológicas e interesses que os sustentam, tanto (estaticamente) um momento determinado como quando essas características se desenvolvem e modificaram (dinamicamente) através do tempo.

25. A sempre possível extensão e retração dos direitos políticos, sociais e humanos e, abrangendo todos eles, a grande questão - política e moral - dos direitos e capacidades que habilitam a agência, são o campo no qual, na democracia, tem se jogado e se continuará a jogar na política. 